UNIVERSIDADE DE SÃO PAULO

FACULDADE DE FILOSOFIA, LETRAS E CIÊNCIAS HUMANAS

DEPARTAMENTO DE HISTÓRIA

PROGRAMA DE PÓS-GRADUAÇÃO EM HISTÓRIA SOCIAL

FREDERICO SOUZA DE QUEIROZ ASSIS

Para Além do Cachimbo de Magritte: Messianismo e Utopia na Construção da Figura do Subcomandante Marcos 
UNIVERSIDADE DE SÃO PAULO

FACULDADE DE FILOSOFIA, LETRAS E CIÊNCIAS HUMANAS

DEPARTAMENTO DE HISTÓRIA

PROGRAMA DE PÓS-GRADUAÇÃO EM HISTÓRIA SOCIAL

\section{Para Além do Cachimbo de Magritte: Messianismo e Utopia na Construção da Figura do Subcomandante Marcos}

Dissertação apresentada ao programa de Pós-Graduação em História Social da Faculdade de Filosofia, Letras e Ciências Humanas da Universidade de São Paulo, para obtenção do título de mestre em História.

Orientador: Prof. Dr. Robert Sean Purdy 
ASSIS, Frederico Souza de Queiroz. Para Além do Cachimbo de Magritte: Messianismo e Utopia na Construção da Figura do Subcomandante Marcos. Dissertação apresentada ao programa de Pós-Graduação em História Social da Faculdade de Filosofia, Letras e Ciências Humanas da Universidade de São Paulo, para obtenção do título de mestre em História.

Email: frederico.assis@usp.br

Aprovado em:

Banca Examinadora

Prof. Dr.

Instituição:

Julgamento:

Assinatura:

Prof. Dr. Instituição:

Julgamento: Assinatura:

Prof. Dr. Instituição:

Julgamento: Assinatura: 
A Thyrso Francisco de Queiroz Assis, meu avô, cuja saudade corta como aço de navalha. 
A mí solo me matarán, pero mañana volveré y seré millones.

Tupac Katari, 1781

Beneath this mask there is more than flesh. Beneath this mask there is an idea, Mr. Creedy, and ideas are bulletproof.

"V for Vendetta", 2005 


\section{Resumo}

ASSIS, Frederico Souza de Queiroz. Para Além do Cachimbo de Magritte: Messianismo e Utopia na Construção da Figura do Subcomandante Marcos. 2013. 126 f. Dissertação (Mestrado em História Social), Faculdade de Filosofia, Letras e Ciências Humanas da Universidade de São Paulo, São Paulo.

O trabalho tem o objetivo central de identificar como se construiu historicamente a figura do Subcomandante Marcos, na esteira do processo de formação do movimento zapatista em Chiapas. Marcos, cuja identidade era ocultada por si mesmo (embora o governo mexicano tenha declarado publicamente, em 1995, que ele era o professor Rafael Sebastián Guillén Vicente), é o principal porta-voz do Exército Zapatista de Libertação Nacional (EZLN) e destaca-se como figura-símbolo do referido movimento. Diante disso, busca-se apresentar a importância chave do indivíduo para o movimento zapatista (no plano intelectual e político), bem como compreender como se deu a dissolução de sua própria individualidade - no plano simbólico - na medida em que Marcos pareceu encarnar o ideário revolucionário zapatista. A ênfase analítica, para tanto, recairá sobre os aspectos de messianismo inseridos nesse processo, assim como sobre os elementos que sinalizem em Marcos a representação da própria experiência utópica, para que então se compreenda as razões pela quais sua liderança pareceu ter uma dimensão sui generis. Tal análise, feita a partir do levantamento de fontes primárias e da revisão da literatura secundária, mostra-se necessária frente à constatação de que o zapatismo constituiu-se como um dos movimentos políticos mais relevantes da contemporaneidade. Assim, realizando um estudo sistemático desse conjunto de aspectos, busca-se articular os temas de modo pertinente, para que se compreenda, então, o significado histórico deste ator político contemporâneo.

Palavras-Chave: Subcomandante Marcos; EZLN; Zapatismo; Chiapas, México. 


\begin{abstract}
ASSIS, Frederico Souza de Queiroz. Beyond Magritte's Pipe: Messianism and Utopia in the Construction of Subcomandante Marcos. 2013. $126 \mathrm{f}$. Thesis (Master's Degree in Social History), Faculdade de Filosofia, Letras e Ciências Humanas da Universidade de São Paulo, São Paulo.
\end{abstract}

This work aims to identify the historical construction of Subcomandante Marcos' image, in the wake of the process of the construction of the Zapatista movement in Chiapas, Mexico. Marcos, whose real identity is hidden by himself (though the Mexican government publicly declared in 1995 that he is Professor Rafael Sebastián Guillén Vicente), is the main spokesperson of the Zapatista Army of National Liberation (EZLN) and stands as a symbol-image of the movement. Therefore, the dissertation seeks to present this individual's key importance to the movement (in the intellectual and political spheres), as well as understanding the dissolution of his own individuality (in the symbolic sphere) as Marcos seems to incarnate the revolutionary ideas of Zapatismo itself. The analytical emphasis, therefore, is on the messianist aspects inserted in this process, as well as on the elements that demonstrate representations of his own utopian existence, in order to understand the reasons why his leadership seems to have a sui generis dimension. This analysis, based on a thorough survey of primary and secondary sources, is relevant because the Zapatistas have established themselves as one of the most relevant contemporary political and social movements. Thus, conducting a systematic study of these aspects, it seeks to understand the historical importance of Subcomandante Marcos within the context of the rise of the Zapatistas. Keywords: Subcomandante Marcos; EZLN; Zapatismo; Chiapas; Mexico. 


\section{SUMÁRIO}

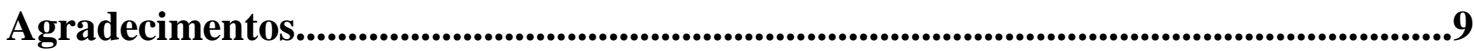

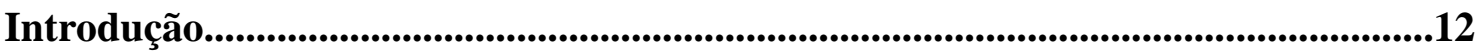

Parte I - A Vida e a Morte de Rafael Guillén............................................................26

Parte II - A Morte e a Vida de Marcos.......................................................................38

Parte III - O Rei está Nu! A Construção do Mito Subcomandante

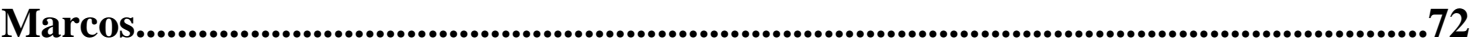

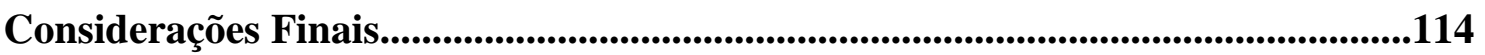

Referências Bibliográficas............................................................................119 


\section{Agradecimentos}

Agradeço inicialmente ao Professor Sean Purdy pela orientação em todo o processo de pesquisa, onde encontrei um permanente canal aberto de diálogo. Agradeço sobretudo pela paciência e atenção demonstradas.

Tive o privilégio de estar junto a uma geração incrível no Bacharelado de Relações Internacionais da USP, pessoas especiais com quem construi laços de amizade e a quem devo boa parte de minha formação política e intelectual. Agradeço - com saudades - pela época de movimento estudantil, no Centro Acadêmico Guimarães Rosa, o "Guima". Aos companheiros da chapa "Sete de Ouros", a cada membro das gestões "Veredas", da querida "Terceira Margem do Rio", da "Meio da Travessia" e d"“A Hora e Vez": muito obrigado, "velhos"! Não tenho como deixar de agradecer nominalmente a amizade de Bruno Zanetta, Caio Favaretto, Ernesto Salles, Felipe Teixeira Gonçalves, Jonas Medeiros, José Henrique Bortoluci, Leonardo Fontes, Melina Rombach e Sérgio Guedes Reis.

Agradeço aos professores que tive durante a graduação na Universidade de São Paulo; em especial: Maria Hermínia Tavares de Almeida, coordenadora do Bacharelado em Relações Internacionais e diretora do IRI-USP, com quem tive a oportunidade de travar um diálogo sempre franco durante dois mandatos como Representante Discente na Congregação do IRI (e agora mais um como representante dos ex-alunos); Peter Demant, quem me abriu as portas para ser monitor do curso "Globalização em Perspectiva Histórica" e me proporcionou uma experiência bastante enriquecedora; Leila Leite Hernandez, quem me ajudou a dar os primeiros passos no mundo da pesquisa acadêmica, por quem tenho muita consideração; e Nicolau Sevcenko, cujas aulas inspiradoras me abriram horizontes e aguçaram meu senso crítico.

Agradeço a todos os professores que tive antes de entrar na universidade, a quem homenageio nos nomes da Professora Alice e da Professora Áurea.

Agradeço a Carlota Moura e a Pedro Smolka, diretores da Escola Superior de Administração, Marketing e Comunicação (ESAMC) de Santos, onde tive a imensa felicidade de dar aulas para o curso de Relações Internacionais durante dois anos: muito obrigado pela oportunidade que me proporcionaram. Em especial, gostaria de agradecer 
imensamente a cada aluno(-professor) com quem dividi uma sala de aula e com quem aprendi constantemente a me transformar num professor(-aluno).

Agradeço a todos os companheiros do Coletivo Alvorada Vermelha, grupo junto a quem tenho o prazer de militar no Partido dos Trabalhadores - mais um grupo de jovens a se somar nessa longa tradição de lutas, cujo objetivo é contribuir, na medida de nossas humildes capacidades, para a construção de uma sociedade mais justa e igualitária, que seja capaz de escrever as linhas de sua própria história: Andreza Galli, Anita Stefani, Danilo Bertazzi, Danilo Fiore, Éder Terrin, Fernanda Lima, João Paulo Paixão, Luis Henrique Campos, Marcello Baird, Marcos Lopes Campos, Mariana Brito, Nádia Nakamura Vieira, Pedro Henrique Lopes Campos, Talita Capela, Tassia Toffoli e Thiago Badaró. Tenho muito o que aprender com cada um de vocês. Em especial agradeço a Felipe Teixeira Gonçalves, com quem trabalhei e aprendi muito, a Ernesto Salles e a Leonardo Fontes.

Agradeço imensamente ao Prefeito Fernando Haddad e à Vice-prefeita Nádia Campeão, com quem tive a oportunidade de estar em contato e aprender muito desde a pré-campanha das eleições municipais de 2012. A Cida Perez, Luís Fernando Massonetto e Gustavo Vidigal, com quem trabalhei na equipe do programa de governo e no governo de transição - certamente uma das épocas mais intensas e de grande aprendizado em minha vida.

Agradeço imensamente a Leonardo Barchini, Vicente Trevas, Paulo Massi Dallari e Marcelo Costa e à toda equipe da Secretaria Municipal de Relações Internacionais e Federativas da Prefeitura de São Paulo; em especial, agradeço às queridas Cássia Costa, Guísela de Pereira, Jessica Marano e Luiza Pinheiro - a quem devo também agradecer pela valiosa ajuda na tradução de citações desta dissertação.

Agradeço aos grandes amigos, parceirinhos de sempre, Bruno Corrêa de Queiroz, Calixto Freitas Filho, Diogo Venturelli, Mariana Chagas, Rodrigo Venâncio Castanho e Vítor Cavina, responsáveis por momentos agradáveis e com que sei que posso contar sempre.

Agradeço ao Professor Flavio de Campos e a todo pessoal do LUDENS (Núcleo Interdisciplinar de Estudos Sobre Futebol e Modalidades Lúdicas). 
Agradeço a oportunidade de ter frequentado na pós-graduação as excelentes aulas dos professores: Eduardo Natalino dos Santos, Francisco de Assis Queiroz, Maria Lígia Coelho Prado e Renato Braz Oliveira de Seixas.

Agradeço as valiosas contribuições dos professores da minha banca de qualificação: Renato Braz Oliveira de Seixas e Pedro Ortiz. Espero que o resultado final desta pesquisa faça jus às expectativas depositadas. E agradeço desde já aos membros da banca de defesa do mestrado.

Aos meus pais, Sílvio e Nina, e ao meu irmão André, serei eternamente grato por tudo.

À Luciana, agradeço por ser parte da minha vida há tanto tempo. 


\section{Introdução}

O trabalho tem o objetivo central de identificar como se construiu historicamente a figura do Subcomandante Marcos, na esteira do processo de formação do movimento zapatista em Chiapas. Marcos, cuja identidade era ocultada por si mesmo (embora o governo mexicano tenha declarado publicamente, em 1995, que ele era o professor Rafael Sebastián Guillén Vicente), é o principal porta-voz do Exército Zapatista de Libertação Nacional (EZLN) e destaca-se como figura-símbolo do referido movimento. Diante disso, busca-se apresentar a importância chave do indivíduo para o movimento zapatista (no plano intelectual e político), bem como compreender como se deu a dissolução de sua própria individualidade - no plano simbólico - na medida em que Marcos pareceu encarnar o ideário revolucionário zapatista. A ênfase analítica, para tanto, recairá sobre os aspectos de messianismo inseridos nesse processo, assim como sobre os elementos que sinalizem em Marcos a representação da própria experiência utópica, para que então se compreenda as razões pela quais sua liderança pareceu ter uma dimensão sui generis. Tal análise, feita a partir do levantamento de fontes primárias e da revisão da literatura secundária, mostra-se necessária frente à constatação de que o zapatismo constituiu-se como um dos movimentos políticos mais relevantes da contemporaneidade. Assim, realizando um estudo sistemático desse conjunto de aspectos, busca-se articular os temas de modo pertinente, para que se compreenda, então, o significado histórico deste ator político contemporâneo.

Na madrugada de $1^{\circ}$ de Janeiro de 1994, cerca de três mil indígenas insurgentes armados tomaram o controle de quatro municípios do estado de Chiapas: San Cristóbal de las Casas, Ocosingo, Altamirano e Margaritas. Tomaram uma estação de rádio, atacaram um quartel do Exército e divulgaram a "1a Declaração da Selva Lacandona", um manifesto à sociedade afirmando as condições hostis enfrentadas pelas comunidades locais, declarando guerra ao governo e clamando por apoio popular. ${ }^{1}$ O presidente da República Carlos Salinas de Gortari rapidamente enviou mais de dez mil homens para combater os membros do Exército Zapatista de Libertação Nacional, o EZLN. Os autointitulados zapatistas, contudo, contribuíram para que se desse primeiro grande

\footnotetext{
1 BUENROSTRO y ARELlANO, Alejandro. As Raízes do Fenômeno Chiapas: o Já Basta da Resistência Zapatista. São Paulo: Alfarrábio, p.15
} 
passo para que a imagem mexicana - tanto em âmbito nacional como, principalmente, no internacional - de estabilidade e progresso começasse a ruir. ${ }^{2}$

A partir de então, surgia no cenário político mexicano um novo ator: o Subcomandante Insurgente Marcos, cuja identidade mantinha-se em mistério, em função do intermitente uso de balaclavas (também chamadas de passa-montanha) e da deliberada negação de seu próprio passado. Marcos apresentava-se como o porta-voz do comando militar (e não propriamente seu líder), declarando publicamente as demandas das comunidades chiapanecas, propalando princípios de não-vanguardismo político e não-disputa pelo poder, bem como elucidando o processo de formação do movimento ao qual estava ligado. Em suas palavras:

Nós chegamos à selva como uma clássica elite revolucionária em busca desse sujeito, o proletariado, no caso da revolução marxista-leninista. Mas essa proposta inicial entrou em choque com as propostas das comunidades indígenas, que têm outro substrato, uma complexa pré-história de emergências e insubmissões. Nós modificamos nossa proposta interativamente. O EZLN não nasce de propostas urbanas, mas tampouco de propostas vindas exclusivamente das comunidades indígenas. Nasce dessa mescla, desse coquetel molotov, desse choque que produz um novo discurso. O que dissemos é que a transformação histórica não deve ser feita à custa da exclusão de setores da sociedade. ${ }^{3}$

Progressivamente, sua imagem como espécie de "anti-herói" se consolidava no imaginário político, transcendendo, inclusive, as fronteiras nacionais mexicanas. Baschet $^{4}$ e Buenrostro y Arellano ${ }^{5}$ identificam claramente que vários dos princípios defendidos pelo Subcomandante Marcos serviriam de inspiração para o surgimento do denominado altermundismo, materializado nos movimentos antiglobalização. A grande repercussão nacional e internacional, nos círculos políticos, midiáticos e acadêmicos, fez com que alguns rótulos fossem atribuídos a Marcos, como "novo Che Guevara", 6

\footnotetext{
${ }^{2}$ GILBRETH, Chris; OTERO, Gerardo. "Democratization in Mexico: The Zapatista Uprising and Civil Society”. Latin American Perspectives 28(4): 7-29, 2001, pp.11-12.

3 AREllanO, A. B.; OLIVEIRA, A. U. (Org.). Chiapas: construindo a esperança. São Paulo: Paz e Terra, 2002, p.42.

4 BASCHET, Jérôme. L'étincelle Zapatiste: Insurrection Indienne et Résistance Planétaire. Paris: Denoël, 2004.

${ }^{5}$ BUENROSTRO y ARELLANO, Op. cit., 2002.

6 "Como muitos tinham o mito de Che Guevara e gostavam de palavras como revolução e guerrilha, a história de um novo homem que passou dez anos na selva, uniu as pessoas para um levante e que tinha uma imagem forte usando sua máscara fez do Subcomandante Marcos um novo Che" (FIGUEIREDO, 2006, p.23).
} 
"terrorista" ou até mesmo como "popstar" (como o denominou a BBC) e sex-symbol, entre outros.

Em 1995, o governo central mexicano, na administração do Presidente Ernesto Zedillo (1994-2000), declarou que havia descoberto a identidade oficial de Marcos, identificando-o como Rafael Sebastián Guillén Vicente, cidadão de Tampico, do Estado de Tamaulipas, ex-aluno de Filosofia da Universidade Nacional Autônoma do México (UNAM), professor universitário e militante comunista. Embora praticamente não haja nenhuma dúvida que o Subcomandante e Rafael Guillén sejam a mesma pessoa, Marcos nunca assumiu sua verdadeira identidade. Segundo ele, "Marcos é o nome de um colega que morreu, e sempre usamos os nomes daqueles que morreram nesta idéia de que um não morre se a luta continuar". 7

Nessa esteira, parece se desenvolver o ponto crucial para o entendimento do que sua figura representa historicamente. Norteados pela linha de sua afirmação, parece-nos que a figura do Subcomandante Marcos, construída no bojo do processo de formação do movimento zapatista, adquiriu um caráter sui generis tal como as inovações trazidas pelo próprio movimento. Com efeito, o processo ocorreu em uma via de mão dupla: além de sua importância pessoal (intelectual e política) como agente na formulação dos princípios zapatistas, Marcos dissolveu sua própria individualidade, representando a encarnação do ideário que propunha e congregando imageticamente em torno de si todos os novos sujeitos de sua revolução (vide os inúmeros cartazes dos militantes e/ou simpatizantes do zapatismo com os dizeres "Todos Somos Marcos"). O Subcomandante, munido nas aparições públicas de seu aparato "icônico" - blusa militar, calça preta, coturno, cartucheiras no peito, boina, um fone de ouvido de comunicação de rádio, balaclava e cachimbo - parece nutrir-se dessa ambivalência entre os aspectos messiânicos que se coadunam com o conteúdo de autonomia (enquanto exercício de livre determinação dos povos e organização horizontal) do próprio projeto utópico zapatista.

Em resumo, as palavras de Naomi Klein delineiam o significado histórico recuperado pela figura do Subcomandante, de um modo bastante representativo:

\footnotetext{
${ }^{7}$ Este não seria, portanto, um acrônimo, como alguns têm sugerido, das comunidades onde o EZLN primeiro se levantou (Las Margaritas, Altamirano, Rancho Novamente, Comitan, Ocosingo, Oxchuc e San Cristobal).
} 
Marcos, a quintessência do anti-líder, insiste que sua máscara preta é um espelho, de modo que 'Marcos é gay em San Francisco, negro na África do Sul, asiático na Europa, um chicano em San Ysidro, um anarquista na Espanha, um palestino em Israel, um índio maia nas ruas de San Cristobal, um judeu na Alemanha, um cigano na Polônia, um mohawk em Quebec, um pacifista na Bósnia, uma mulher sozinha no metrô às 10 da noite, um camponês sem-terra, um membro de uma gangue nas favelas, um trabalhador desempregado, um estudante infeliz e, é claro, um zapatista nas montanhas' (palavras do próprio Marcos). Em outras palavras, ele é simplesmente nós:.. nós somos o líder que estávamos à procura (tradução nossa). ${ }^{8}$

O cumprimento do objetivo central implica em trabalhar com três questões fundamentais: a primeira questão diz respeito ao exercício de examinar documentos que descrevam a trajetória de Rafael Sebastián Guillén Vicente, que se apresenta como a identidade oficial do Subcomandante Marcos; desta maneira, busca-se relacionar sua vida pregressa - e o contexto em que foi formado - com a construção do ícone político em que ele se transformou. Cabe, assim, investigar sua vida de militância, tanto como estudante da UNAM, quanto como professor universitário, bem como traços relevantes no âmbito de sua vida pessoal, tal como sua família politizada e os motivos conjeturados por seu sumiço. No conjunto, parece importante empreender tal estudo biográfico anterior ao ingresso de Guillén em Chiapas, a fim de atentar para os aspectos relevantes que apontam para o foco de nosso trabalho.

A segunda questão é relativa ao estudo do processo histórico de entrada dos jovens militantes mexicanos, de matriz marxista (categoria social em que Rafael Guillén se enquadrava), na selva de Chiapas, que, de início, tentariam formar grupos guerrilheiros com o objetivo de realizar uma luta armada na região contra o governo central - a partir da ideia de que seriam motores da conscientização indígena - e que originou, em novembro de 1983, o EZLN. Nesse sentido, busca-se compreender os desdobramentos de sua atuação, a fim de identificar os fatores que, conjugados, culminaram justamente no abandono de certos princípios de um marxismo mais ortodoxo. Cabe essencialmente verificar em que medida o Subcomandante Marcos

\footnotetext{
${ }^{8}$ KLEIN, Naomi (2002). "Farewell to the End of History: Organization and Vision in Anti-Corporate Movements". The Socialist Register, pp.1-14. Marcos, the quintessential anti-leader, insists that his black mask is a mirror, so that 'Marcos is gay in San Francisco, black in South Africa, an Asian in Europe, a Chicano in San Ysidro, an anarchist in Spain, a Palestinian in Israel, a Mayan Indian in the streets of San Cristobal, a Jew in Germany, a Gypsy in Poland, a Mohawk in Quebec, a pacifist in Bosnia, a single woman on the Metro at 10 p.m., a peasant without land, a gang member in the slums, an unemployed worker, an unhappy student and, of course, a Zapatista in the mountains'. In other words, he is simply us: we are the leader we've been looking for.
} 
influencia nesse processo - levando-se, ainda, em conta o contexto mais amplo de adoção de políticas macroeconômicas neoliberais pelo governo central do México.

A terceira questão se refere à observação de documentos que revelem o modo como o Subcomandante Marcos foi retratado após o levante de janeiro de 1994, na perspectiva da construção do "culto a Marcos", em especial atentando para os pontos em que seu papel como (anti-)líder pareceu se coadunar justamente com os princípios do movimento zapatista. Diante disso, faz-se necessário observar as respostas de Marcos (presentes em comunicados, declarações, entrevistas, poesias, vídeos e livros) aos questionamentos sobre sua figura, a fim de identificar características apreendidas em documentos produzidos por ele mesmo; e atentar para as adjetivações atribuídas a Marcos, a fim de compreender as representações construídas em torno de sua figura. Vale assinalar que, nesse ponto, a análise deve ser demarcada cronologicamente, observando documentos produzidos entre $1^{\circ}$ de janeiro de 1994 , quando se tornou uma pessoa pública, e o momento imediatamente posterior à revelação de sua identidade oficial pelo governo central, que se deu em 9 de fevereiro de 1995.

No conjunto, busca-se empreender um abrangente esforço de levantamento, revisão e sistematização da literatura sobre a trajetória histórica do Subcomandante Marcos e o seu significado para o movimento zapatista, aproximando os múltiplos entendimentos a respeito do tema, a fim de enriquecer a pesquisa.

Uma pesquisa mais aprofundada sobre a trajetória história do Subcomandante Marcos, enquanto construção de um sujeito político "mitificado", permite uma melhor compreensão acerca do próprio fenômeno zapatista, pela sistematização de um conjunto de aspectos que, relacionados, dão condições à emergência de um dos movimentos políticos mais relevantes da contemporaneidade. O conflito em Chiapas teria grande significado para o contexto social, político e econômico no México, bem como para sua reputação internacional (até então, em alto nível perante os policy-makers dos países mais desenvolvidos), para a intelectualidade (especialmente para os que compartilhavam visões do denominado "marxismo ortodoxo") e para alguns movimentos vindouros de contestação ao capitalismo, como os críticos à globalização de Seattle (1999) e o Fórum Social Mundial (cuja primeira edição se daria no ano de 2001).

\footnotetext{
${ }^{9}$ Expressão de uso corrente nas fontes primárias e secundárias que tratam da proeminência de Marcos após o levante.
} 
Nosso argumento é que a análise do caso da emergência do (anti-)líder mexicano, a partir do olhar à história dos povos periféricos do país, nos permite não somente uma melhor compreensão dos processos sociais e políticos que lhe são peculiares, mas também pode servir como caso paradigmático, a partir do qual se poderia extrair um grande número de questões com relação a movimentos políticos e sociais contemporâneos em toda a região latino-americana - sobretudo quanto aos que possam apresentar maior proximidade com a realidade social daquele do país estudado. Este trabalho, longe de propor resolver tais questões, procura contribuir para o esforço coletivo de compreensão dessas sociedades e dos processos políticos em curso a partir do caso proposto. ${ }^{10}$

Em primeiro lugar, é preciso salientar a relevância acadêmica e política de nossa proposta. Quanto ao primeiro ponto, no Brasil, o número de pesquisas relacionadas ao tema do zapatismo já não chega a ser insignificante, atestada pelo número até razoável de especialistas e de publicações sobre o tema específico; ainda, a presença de temáticas sobre o México - país com crescente relevância geopolítica no cenário internacional nos programas brasileiros de Pós-Graduação já não é tão tímida. Por outro lado, existem poucos estudos cujo foco recaia sobre o papel e o significado do Subcomandante Marcos para o movimento e que sistematizem a trajetória histórica deste ator proeminente na política contemporânea latino-americana.

A reversão desse quadro se faz necessária tanto pela relevância acadêmica em estudar a região quanto pela sua inquestionável importância política - segundo ponto aqui destacado. A insurreição zapatista repercutiu em debates acadêmicos ao redor do mundo: correntes distintas do ponto de vista ideológico buscavam compreender o caráter do movimento, em meio a um contexto de "consenso global" quanto ao triunfo final do capitalismo e da democracia liberal, fundamentado pelas teses do "fim da história". ${ }^{11}$ A resposta contra-hegemônica zapatista acabou por questionar tanto os alicerces teóricos da intelectualidade crítica quanto por colocar em xeque o domínio da ortodoxia econômica no México. ${ }^{12}$ A prática política zapatista nega a política eleitoral e

\footnotetext{
${ }^{10}$ Conforme o raciocínio de Ortiz, "o zapatismo é um sintoma do que está ocorrendo no mundo, algo maior e mais geral, que em cada continente aparece de uma forma. Em cada lugar essa rebeldia apresenta formas e reivindicações próprias. Por isso dizemos que as rebeliões pelo mundo afora têm muito do zapatismo". (ORTIZ, Pedro H. F. "Ya Basta!". Atenção, 2(8), 1996).

${ }^{11}$ Ver, por exemplo, a célebre tese de Fukuyama (1992).

12 Ainda, o levante zapatista representou uma evidência da quebra do pacto nacional historicamente apregoado pelo Partido Revolucionário Institucional (MORRIS, 2001, p.135).
} 
se opõe radicalmente à tomada de poder e à conquista do Estado; sua dinâmica social é fruto da interação do mundo maia, dos padres progressistas ligados à Teologia da Libertação e dos jovens revolucionários de origem urbana e marxista. ${ }^{13}$ Diante desses novos ingredientes, pode-se dizer que as mesmo análises sobre as possibilidades da esquerda nos dias de hoje são, em certa medida, referenciadas pela experiência zapatista, dentro da qual o Subcomandante Marcos exerceu um papel inquestionável. Por isso, parece-nos extremamente importante compreender o processo que deu origem ao vínculo peculiar entre tal agente individual e a coletividade revolucionária. Conforme aponta Adolfo Gilly, essa conjunção de fatores deu ensejo à relevância do Subcomandante Marcos dentro do próprio movimento:

Nesta combinação singular de mitos antigos, comunidades mobilizadas, exército clandestino, golpes de cena, recursos literários e iniciativa política, a figura do chefe militar da rebelião, Subcomandante Marcos, é extremamente importante... O mérito mais importante de Marcos, se for necessário designar um, seria então que ele sabia o suficiente, primeiro para compreender e assimilar a substância e, então, para ser o mediador ou guia pelo qual sua imagem foi transmitida para a sociedade urbana. ${ }^{14}$

Além disso, torna-se válida a proposta de pesquisa também como tentativa de jogar luz sobre processos históricos que se desdobram até o tempo presente. O Ya basta! (Já chega!, em tradução para o português) da primeira declaração zapatista em 1994 foi fundamental no encerramento dos 71 anos no poder por parte do Partido Revolucionário Institucional, ${ }^{15}$ na reorganização da sociedade civil mexicana na segunda metade da década de 1990 e nos anos 2000, ${ }^{16}$ bem como na expressão, por exemplo, da já mencionada rearticulação em âmbito global da insatisfação com a estrutura capitalista existente, materializada nos movimentos altermundistas.

\footnotetext{
${ }^{13}$ Segundo Buenrostro y Arellano (2002), o sincretismo teórico efetivado transcende todos os paradigmas existentes, incluindo-se aí o pacifismo de Martin Luther King e Gandhi e o marxismo de Che Guevara, Mao Tse Tung e Lênin.

${ }^{14}$ GILLY, Adolfo. "Chiapas and the Rebellion of the Enchanted World". In: NUGENT, Daniel. Rural Revolt in Mexico. Durham: Duke University Press, 1998, p.312.

${ }^{15}$ Nas eleições presidenciais de 2000, venceu Vicente Fox, pelo Partido da Ação Nacional (PAN).

${ }^{16}$ Vale mencionar dois eventos históricos que são reflexos diretos da organização zapatista: 1) no ano de 2005, os zapatistas iniciariam a chamada "Outra Campanha" (a partir da qual o Subcomandante Marcos utilizou o codinome Delegado Zero), na qual buscam interagir e promover trocas de experiências com outras comunidades oprimidas mexicanas (operários, mulheres, homossexuais etc.) de forma a promover a interconexão horizontal entre focos de luta anticapitalista no mundo contemporâneo (Wallerstein, 2006); 2) Em 2006, o México viria o acontecimento de uma rebelião aos moldes chiapanescos no estado vizinho de Oaxaca.
} 
É possível notar a existência de uma vasta literatura estrangeira que busca compreender as origens do levante do EZLN na região. ${ }^{17} \mathrm{E}$, por isso, torna-se extremamente válido empreender uma pesquisa de mestrado sob a perspectiva da construção da figura do Subcomandante Marcos, na esteira do processo de formação do movimento zapatista, levantando fontes primárias e revisando a literatura secundária, a fim de examinar suas formulações em relação às questões básicas que norteiam nossa proposta de pesquisa. Tais estudos e a perspectiva utilizada serão brevemente expostos abaixo.

Tendo isso em vista, é necessário destacar, como forma de esquematização, que a bibliografia a ser apresentada divide-se em três grandes conjuntos: conteúdo de núcleo; conteúdo "instrumental”; e conteúdo de base (teórica e historiográfica).

Dentro do primeiro conjunto de trabalhos, deve-se apontar a literatura que observa fatores particulares da realidade chiapaneca sobre os quais almejamos nos debruçar: é preciso destacar estudos de literatura secundária que tratam especificamente da trajetória histórica do Subcomandante Marcos tais como seu passado como o estudante (e depois professor) Rafael Guillén, seu ingresso em Chiapas, seu papel na formulação dos princípios zapatistas, e seu significado político, intelectual e simbólico para o próprio movimento. Sob essa perspectiva, deve-se mencionar os trabalhos de Grange e Rico ${ }^{18}$, Montalbán ${ }^{19}$, Conant $^{20}$, Vargas $^{21}$, Figueiredo ${ }^{22}$, Fuser $^{23}$ e Henck. $^{24}$

O segundo conjunto diz respeito às fontes primárias de duas ordens, quais sejam, as de autoria de Marcos e as da cobertura da imprensa mexicana e internacional. Há

\footnotetext{
${ }^{17}$ Os estudos sobre o tema são elaborados e debatidos amplamente pela comunidade norte-americana e mexicana de especialistas. Como é sabido, a produção brasileira acerca de Chiapas ainda é relativamente limitada e mesmo a literatura traduzida para língua portuguesa é escassa e pouco acessível em bibliotecas.

${ }^{18}$ GRANGE, Bertrand de la; RICO, Maité. Marcos: La Genial Impostura. Madrid: Alfaguara, Santillana Ediciones Generales, 1998.

${ }^{19}$ MONTALBÁN, Manuel Vázquez. Marcos: el Señor de los Espejos. Madrid: Aguilar, 1999.

${ }^{20}$ CONANT, Jeff. A Poetics of Resistance: the Revolutionary Public Relations of the Zapatista Insurgency. Oakland, CA: AK Press, 2010.

21 VARGAS, Sebastião. Mística de Resistência: culturas, histórias e imaginários rebeldes nos movimentos sociais latino-americanos. Tese (Doutorado em História Social) - Faculdade de Filosofia, Letras e Ciências Humanas, Universidade de São Paulo, São Paulo, 2007.

${ }^{22}$ FIGUEIREDO, Guilherme Gitahy de. A Guerra é o Espetáculo: Origens e Transformações do Exército Zapatista de Libertação Nacional. São Carlos: RiMa, FAPESP, 2006.

${ }^{23}$ FUSER, Igor. México em Transe. São Paulo: Scritta, 1995.

${ }^{24}$ HENCK, Nick. Subcommander Marcos: The Man and the Mask. London: Duke University Press, 2007.
} 
uma quantidade razoável de declarações, discursos, entrevistas (audiovisuais e em mídia impressa) $)^{25}$ dadas pelo porta-voz do movimento zapatista, que tocam na temática de sua identidade, na relação peculiar travada entre sua individualidade "dissolvida" e as ideias do coletivo. Existem, também, alguns livros em que o Subcomandante Marcos é autor ou coautor, e que, de mesmo modo, nos deteremos na articulação dos eixos temáticos que propomos estudar. Além disso, há um rico acervo de notícias que desvelam o retrato construído por outrem acerca da imagem de Marcos, como pode se verificar em canais midiáticos como a BBC, The New York Times e Le Monde. Utilizamo-nos fartamente de duas fontes mexicanas, a saber, La Jornada e a revista Proceso - ambas cobriram de modo intenso e independente o levante zapatista e seus desdobramentos durante os anos de 1994 e 1995, trazendo uma série de entrevistas com o Subcomandante Marcos, analistas e intelectuais, habitantes chiapanecos, e, depois do desmascaramento, familiares e amigos de Guillén. Em resumo, cada documento examinado pode, de modo articulado, contribuir significativamente para nosso estudo, ao realizarmos um amplo e sistemático levantamento e revisão das fontes primárias sobre o Subcomandante Marcos, a partir dos quadros referenciais que objetivamos pesquisar. Praticamente todos os tipos de documentos foram encontrados disponíveis na internet, em geral em espanhol ou inglês. ${ }^{26}$

Por último, o terceiro conjunto diz respeito ao conteúdo que pode servir de base histórica e teórica para o trabalho, uma vez que oferecem subsídios para a compreensão do período e dos temas a serem estudados. As obras que fornecem base histórica são as que se relacionam mais amplamente com a história geral do México (e particularmente com a história de Chiapas) no período e estão todas listadas nas referências bibliográficas. Quanto às obras que fornecem base teórica, é preciso destacar, ainda que muito sucintamente, entre os trabalhos publicados indicados, a importante contribuição de Michael Löwy (obras diversas). Para o autor, o zapatismo aparece como portador de um reencantamento do mundo, por considerá-lo um movimento repleto de utopias (...) e

\footnotetext{
25 Pode-se, por exemplo, enunciar as entrevistas a Huerta e Higgins (1999); bem como a célebre entrevista a Garcia Marquez e Roberto Pombo (2001). Sem contar compilações de entrevistas diversas em livros, além da farta documentação audiovisual (acessível na Internet), que pode ser selecionada conforme nossos objetivos de pesquisa. Cabe lembrar que, para Castells (1999), os movimentos sociais devem ser entendidos em seus próprios termos, ou seja, eles são o que dizem ser. Suas práticas (sobretudo as práticas discursivas) são a sua autodefinição.
}

${ }^{26}$ Destacamos os sites: palabra.ezln.org.mx e www.autonomedia.org. 
romantismo. ${ }^{27} \mathrm{E}$, nesse sentido, pareceu pertinente nos ancorarmos na articulação entre o pensamento romântico, enquanto rejeição da autenticidade do mundo moderno, e o ideário zapatista, pela reconstrução de experiências coletivas como alternativa emancipatória. Aí parece residir o nexo crucial entre o recorte proposto e a hipótese, a partir da qual o objetivo desse trabalho se sedimenta, qual seja, a construção da figura do Subcomandante Marcos relacionada ao teor messiânico e à veia utópica do projeto político zapatista - enquanto aglutinador simbólico da tentativa de superação dessas tensões.

A análise das fontes primárias foi complementada por uma sistemática revisão da literatura secundária sobre a formação do movimento zapatista, sobretudo a partir da perspectiva dos estudantes marxistas, com foco nas obras que tratam da trajetória e das idéias do Subcomandante Marcos - tomadas como fontes indispensáveis para a execução do trabalho. A literatura secundária foi composta, predominantemente, por livros, artigos, ensaios e textos extraídos da internet. Assim, desempenhando uma análise cuidadosa dos materiais, a pesquisa pode se tornar algo consistente do ponto de vista acadêmico. $^{28}$

A partir da delimitação de nosso objeto de pesquisa, buscamos realizar uma leitura atenta de obras que identificassem os aspectos fundamentais acerca do papel e do significado do Subcomandante Marcos dentro do movimento zapatista, observando como se constituem as especificidades na relação entre ambos, com o objetivo principal de compreender como se constrói sua (anti-)liderança dentro do EZLN.

O eixo bibliográfico caracterizou-se pelo uso das obras que tratam mais especificamente da vida de Marcos - antes e depois de seu ingresso na Selva Lacandona, em Chiapas. Tais estudos de natureza mais biográfica apresentaram-se como fio condutor de nossa pesquisa, a partir dos quais pudemos extrair um grande número de questões pertinentes aos nossos objetivos. Evidentemente, nossa

\footnotetext{
27 LÖWY, 1997, p.199. O autor afirma, em outra obra (2010) que “o EZLN nasceu da fusão do guevarismo (que não deixa de ter uma dimensão milenarista) de um punhado de militantes urbanos com a revolta 'arcaica' de comunidades indígenas maias e com o messianismo cristão das comunidades de base (fundadas nos anos 70 pelo bispo de Chiapas, monsenhor Samuel Ruiz), sob a égide suprema da legenda milenarista de Emiliano Zapata. O resultado desse explosivo coquetel político-cultural e sócio-religioso foi uma das rebeliões camponesas mais originais dos anos 90 ”.

${ }^{28}$ Além das atividades específicas à pesquisa, o trabalho incluiu freqüência a disciplinas do mestrado, continuação dos estudos da língua espanhola, consulta freqüente ao professor orientador e diálogo com outros acadêmicos que contribuiram com o andamento da pesquisa.
} 
preocupação não foi empreender um estudo meramente biográfico, reduzindo-se a descrever os feitos individuais, visando esgotá-los cronologicamente.

Nosso intuito - como atesta nossa própria hipótese relativa à simbologia em torno da figura do Subcomandante - foi o de compreender fenômenos mais amplos a partir do caso emblemático do Subcomandante Marcos. Com efeito, tudo o que for dito sobre Marcos passa a ser sem sentido se o foco do interesse for individual e não coletivista, ${ }^{29}$ mesmo que ele passe a se caracterizar como ponto focal de uma pesquisa, como é nosso caso: Marcos se apresentaria, portanto, como um one-man movement. ${ }^{30}$

Nesse sentido, foi fundamental a utilização da obra de Henck $^{31}$, Grange e Rico ${ }^{32}$ e Montalbán ${ }^{33}$ - sem apontar, aqui, trabalhos diversos que abordam o papel de Marcos pontual ou transversalmente, e que, igualmente contribuíram para elucidação de questões biográficas em nossa pesquisa.

Foi significativa a contribuição de Nick Henck, primeira biografia em inglês sobre o principal protagonista do movimento. $\mathrm{O}$ autor apresenta uma visão alternativa de Marcos (e, em alguma medida, parece se propor a ser espécie de "biografia definitiva"), tentando desmitificar o personagem (sobretudo no período anterior à insurreição de 1994). Propõe-se, a partir do levantamento de fontes primárias e da revisão da literatura secundária (o livro é bastante rico nesse sentido, inclusive), a realizar um trabalho que não fosse deliberadamente laudatório ou difamatório quanto à figura do Subcomandante, como vinham sendo muitas das publicações veiculadas nos círculos midiáticos e, inclusive, acadêmicos. ${ }^{34}$

Antes de Henck, havia poucos trabalhos com foco no homem Marcos, em sua maioria em espanhol e francês, sendo importante destacar um deles: a polêmica obra de Bertrand de la Grange e Maité Rico, da qual também nos utilizamos. Os autores foram acusados de, durante o ano de 1994, levantar material para servir como propaganda antizapatista, subsidiando sobretudo o serviço de informação do presidente Ernesto

\footnotetext{
${ }^{29}$ MONSIVAÍS, Carlos. "From the Subsoil that the Mask Reveals: The Visible Indian". Proceso, Mar, 1995. In: HAYDEN, 2002, p.127.

${ }^{30}$ Ibidem, p. 128.

${ }^{31}$ HENCK, Op. cit., 2007.

${ }^{32}$ GRANGE; RICO, Op. cit., 1998.

${ }^{33}$ MONTALBÁN, Op. cit., 1999.

${ }^{34}$ Em boa medida, a estruturação temática do livro de Henck nos ajudou a definir a nossa própria estrutura da pesquisa, como será exposto mais adiante.
} 
Zedillo, na tentativa de desmascarar Marcos e os outros zapatistas. ${ }^{35}$ Os autores, entretanto, negam essa afirmação. Respondem argumentando que não pretendiam difamar o Subcomandante, mas sim dar maior complexidade ao personagem (autores alegam que alguns analistas só faltam canonizar Marcos). Grange, que era correspondente do jornal francês Le Monde no México (que o suspenderia em razão daquelas acusações), teve bastante contato com Marcos e passa a imagem de ser pessoalmente ressentido com o porta-voz do movimento. ${ }^{36}$

Tal fato não inviabiliza por completo a leitura da produção. Embora as acusações nos forcem a ler a obra com alguma suspeição, ela se mostrou referência obrigatória, tanto pela quantidade de dados levantados (há diversas entrevistas com personagens ligados de alguma forma ao movimento) quanto pela recorrência com que outros autores acabam travando um diálogo crítico com ela.

No caso de Montalbán, o autor lança mão do material adquirido a partir de uma extensa entrevista com o Subcomandante, onde explora várias das temáticas relativas à sua individualidade, no que tange particularmente aos nossos propósitos - e nessa mesma linha efetuamos a leitura de outras entrevistas, como a de Garcia Marquez e Roberto Pombo.

Outras produções que foram muito importantes para a execução deste trabalho são as de Guilherme Figueiredo, que narra analiticamente as situações das origens e transformações da estratégia do EZLN; de Sebastião Vargas, tese de doutorado que tem preocupação em compreender e analisar as novas formas de cultura política que emergem no campo latino-americano (comparando a mística do EZLN e a do MST brasileiro), ancorado nos estudos dos processos de resistência das populações rurais; de Jeff Conant, cujo objetivo é examinar narrativa dos zapatistas, desemaranhando sua poética de resistência, a partir da observação de Marcos enquanto "relações públicas revolucionário"; e de Igor Fuser, primeira obra em português a tratar do zapatismo, mostra-se referência obrigatória para entender o contexto no qual surge $o$ Subcomandante Marcos e o EZLN.

A exposição dos resultados obtidos obedecerá a estrutura que nos pareceu mais viável a ser construída e será, então, discutido em que medida confirmamos nossas

\footnotetext{
${ }^{35}$ O próprio Nick Henck faz essa ressalva quanto ao livro de Grange e Rico.

${ }^{36}$ VARGAS, 2007, p.94.
} 
hipóteses iniciais, nos aproximamos ou nos afastamos delas, articulando os elementos mais importantes a partir das diversas leituras que fizemos durante o tempo de pesquisa. Nosso trabalho se divide em três partes, cujos desenvolvimentos serão expostos adiante: 1) a vida de Marcos anterior à sua entrada em Chiapas; 2) o período da vivência de Marcos na selva Lacandona até o momento imediatamente anterior à insurreição de $1^{\circ}$ de janeiro de 1994 e; 3) o período compreendido entre a insurreição e o momento imediatamente posterior à descoberta da identidade de Marcos pelo governo mexicano, em 9 de fevereiro de 1995. Em entrevista a Saul Landau, o Subcomandante afirmaria a existência desses "três Marcos diferentes". 37

Na primeira parte de trabalho exporemos a leitura dos textos que remontam à vida de Marcos anterior ao seu ingresso em Chiapas, com a finalidade de observar, em particular, os antecedentes históricos que conformaram a trajetória do professor Rafael Guillén e o levaram a optar pela atuação política naquele Estado. De modo abrangente, examinamos também os eventos históricos que delinearam às perspectivas da militância de esquerda no México, categoria em que Rafael se encaixava.

Em seguida, adentraremos no período de aproximadamente dez anos (19841993) em que Marcos atua no EZLN em Chiapas, antes da insurreição zapatista. Buscamos verificar questões de fundo relevantes, tais como o histórico de exclusão social de Chiapas, um breve histórico de grupos revolucionários no México antes do EZLN, os governos do Partido Revolucionário Institucional (PRI) da década de 80, a formulação e os impactos do NAFTA. O foco, nessa etapa, foi verificar o processo de formação do EZLN, a partir da perspectiva dos militantes comunistas (e não dos padres progressistas ou até mesmo dos indígenas chiapanecos, ambos igualmente importantes para a consolidação da utopia zapatista), observando, especialmente, o papel político e intelectual do Subcomandante Marcos nesses anos.

$\mathrm{Na}$ terceira parte, faremos a sistematização das leituras do período compreendido entre $1^{\circ}$ de janeiro de 1994, data do levante zapatista, e 9 de fevereiro de 1995, data do desmascaramento de Marcos pela Procuradoria-Geral da República Mexicana. Privilegiamos abordar criticamente as fontes e análises que tratassem da questão do uso da máscara e dos aspectos de "teatralidade" do Subcomandante Marcos, verificando como impactam na construção dos significados de sua imagem, associando esse

\footnotetext{
${ }^{37}$ LANDAU, Saul. "In the Jungle with Marcos: an Interview”. Progressive, pp.25-30, 1996.
} 
conjunto de fatores ao novo tipo de liderança política que sua figura sugere. Ainda, discorreremos sobre questões relativa ao messianismo, a fim de fundamentar (do ponto de vista conceitual) a abordagem do caso em questão. E apresentaremos em que medida alguns aspectos da utopia zapatista relacionam-se com a própria figura de Marcos. Vale mencionar que articularemos a leitura relativamente factual - sustentada mormente pelas obras supracitadas de caráter mais biográfico e que serviram, a nosso ver, de modo bastante satisfatório ao proporcionar subsídios históricos imprescindíveis - às abordagens mais analíticas, de modo que pudéssemos verificar as distintas interpretações em relação a cada evento e a cada processo histórico. 


\section{A Vida e a Morte de Rafael Guillén}

“(...) Por eso cuando al mundo, triste contemplo, yo me afano y me impongo ruda tarea y sé que vale mucho mi pobre ejemplo, aunque pobre y humilde parezca y sea. ¡Hay que luchar por todos los que no luchan! ¡Hay que pedir por todos los que no imploran! ¡Hay que hacer que nos oigan los que no escuchan! ¡Hay que llorar por todos los que no lloran! Hay que ser cual abejas que en la colmena fabrican para todos dulces panales. Hay que ser como el agua que va serena brindando al mundo entero frescos raudales. Hay que imitar al viento, que siembra flores lo mismo en la montaña que en la llanura. Y hay que vivir la vida sembrando amores, con la vista y el alma siempre en la altura.

Dijo el loco, y con noble melancolía por las breñas del monte siguió trepando, y al perderse en las sombras, aún repetía: ¡Hay que vivir sembrando! ¡Siempre sembrando!...” (El Sembrador, Marcos Rafael Blanco Belmonte)

A fim de chegarmos a uma compreensão mais plena do processo de construção da figura do Subcomandante Marcos, nos pareceu imperativo levar em conta os acontecimentos antecedentes à sua ida a Chiapas, seja porque nos permitem, no plano individual, conhecer como se forma o homem Rafael Guillén (em termos de personalidade, formação intelectual e política), seja porque nos levam também, no plano coletivo, a compreender o contexto mais amplo dentro do qual se conformam as visões políticas de boa parte da esquerda marxista mexicana, em que pese o fato de as vias institucionais passarem a ser crescentemente obstruídas pelo regime do Partido 
Revolucionário Institucional, o PRI. A maioria das fontes que utilizamos para tratar deste período advém de entrevistas de familiares, amigos e professores de Rafael Guillén (em versões de revistas disponíveis em sites ou compiladas em livros) e do próprio Subcomandante Marcos. No conjunto, buscamos examinar toda a documentação que aborda a trajetória de Rafael Guillén, dando relevo, aqui, aos traços mais relevantes no âmbito de sua vida pessoal que apresentaram ter maior conexão com a figura do ícone político em que ele se transforma, nos termos do objetivo central desta pesquisa.

Rafael Sebastián Guillén Vicente nasceu em Tampico, no Estado de Tamaulipas, ${ }^{38}$ em 19 de junho de $1957,{ }^{39}$ no seio de uma família letrada de classe média-alta, descendentes de imigrantes zamoranos. Quarto de oito filhos, ${ }^{40}$ passou sua infância na Colonia Lauro Aguirre e depois na Colonia Petrolera, na Calle Ébano 205 local onde seus pais ainda moravam à época do desmascaramento do Subcomandante Marcos e que se transformaria em "espécie de santuário para peregrinações de dezenas de jornalistas e curiosos" após o 9 de fevereiro de $1995 .^{41}$

Seu pai, Alfonso Guillén, estimulou desde cedo aos oito filhos a leitura de notícias de jornal, romances e poesias; é ele quem apresentou a Rafael, como exemplo, os autores do chamado "boom latino-americano", cuja influência no Subcomandante Marcos sobressairia abertamente em seus escritos, entrevistas e comunicados. Rafael era considerado por seu pai uma criança precoce, em virtude de recitar, após ter decorado sem saber ler, o poema "El Sembrador" do escritor espanhol Marcos Rafael Blanco Belmonte (1871-1936).

A valorização do exercício intelectual desde casa propiciou que Rafael obtivesse uma educação prematura, mesmo antes de ingressar na escola. Segundo afirmou a Garcia Marquez e Pombo, ${ }^{42}$ sua família estimulava a leitura de noticiários para

\footnotetext{
${ }^{38}$ No Estado de Tamaulipas, famoso pelos ciclones, foi onde operou um pequeno mas influente grupo de maoístas próximos aos irmãos Salinas, Carlos (presidente do México entre 1988 e 1994) e Raúl.

39 A título de curiosidade: em 2010, no mesmo dia, morreria Carlos Monsiváis, declaradamente um dos maiores ídolos do Subcomandante Marcos.

${ }^{40}$ Dos oito filhos do casal Guillén Vicente, sete são homens. A única mulher é Mercedes del Carmen Guillén Vicente, conhecida como Paloma, atualmente subsecretária de Migración, Población y Asuntos Religiosos na Secretaría de Gobernación do Presidente Enrique Peña Nieto. Ela havia ocupado vários cargos na administração pública, sendo eleita deputada pelo PRI nas décadas de 1980 e 1990.

${ }^{41}$ ESPINOSA, Javier. "La verdadera historia del subcomandante Marcos", El Mundo, 26 de fevereiro de 1995.

${ }^{42}$ MARQUEZ, G; POMBO, R. "The Punch Card and the Hourglass: Interview with Marcos". New Left Review, May - June 2001, p.77
} 
alfabetização, a fim de que, idealmente, debates internos fossem suscitados em torno dos temas lidos. Contudo, os padres jesuítas, professores da escola Félix de Jesús Rougier, onde obteve sua educação primária entre 1963 e 1969, afirmaram em diversas entrevistas que Rafael não teria se mostrado a eles uma "criança-prodígio" (ao contrário de seu irmão Alfonso, ele não recebia costumeiramente fitas e medalhas de honra), manifestando seu talento e obtendo maior destaque intelectual ao longo dos anos ${ }^{43}$.

Foi justamente na década de sua infância, nos anos 60, que o regime do PRI começou a sofrer alguns abalos no México. Apesar de três décadas do chamado "Milagre Mexicano", que assegurou crescimento econômico sustentado entre os anos 1940 e 1970, ${ }^{44}$ a insatisfação popular tendia a crescer em razão da insuficiência de canais alternativos para participação política, que não fosse pelas entradas institucionalizadas garantidas pelo priísmo. ${ }^{45}$

A resposta governamental aos descontentamentos culminou no "Massacre de Tlatelolco"46: no dia 2 de outubro de 1968, dez dias antes da abertura dos Jogos Olímpicos da Cidade do México, centenas de estudantes que faziam demonstrações de protesto contra o governo na Plaza de Las Tres Culturas, foram ferozmente reprimidos pelas forças de segurança, em uma ação que acarretou em mortos e feridos e causou grande comoção internacional. Os vários tiros de snipers, disparados pelo Batallón Olimpia e pelo Exército Mexicano, resultaram em várias mortes: ao menos 30, segundo

\footnotetext{
43 O que se assemelharia, em certa medida, ao Subcomandante Marcos, que vai processualmente aprendendo a reformular suas ideias a partir do contato com os povos de Chiapas.

${ }^{44}$ Durante esses anos, a taxa de crescimento do PIB variava entre $3 \%$ e $4 \%$ por ano e a taxa de inflação não passava dos $3 \%$ por ano.

45 Segundo Figueiredo, “o PRI foi idealizado para congregar em um só partido todas as forças políticas que, na promoção de seus interesses, reivindicavam as causas da Revolução. Implantado a partir do Estado em 1928, passou a ter o papel de arena para a disputa dos vários setores segundo regras estáveis, ao mesmo tempo em que visava preservar o poder da facção dominante, 'fazendo que manifestações de posições conflitantes econtrassem canais institucionais para o acordo ou a imposição hierárquica de soluções' (GURZA, 2000, p.10). em relação à ideologia, todos os setores incorporados no PRI adaptavam os seus discursos em torno dos argumentos da 'paz social', dos benefícios para as camadas populares, do progresso material promovido pelo Estado e do nacionalismo. A principal 'linha divisória' da política não estava na dicotomia entre esquerda e direita, e, sim, na organização de interesses no interior ou exterior do Estado. As organizações que tentavam escapar à tutela das instituições oficiais eram sistematicamente reprimidas (GURZA, 2000, pp.10-11). Ou seja, havia canais para a representação de interesses econômicos e a promoção de objetivos pessoais, mas, grosso modo, não era permitido o questionamento da ordem política" (FIGUEIREDO, 2006, p.57).
}

${ }^{46}$ Cf. PONIATOWSKA, Elena, La noche de Tlatelolco. Testimonios de historia oral, de 1971, primeiro grande testemunho dos eventos ocorridos, torna-se uma referência obrigatória sobre o episódio. 
os dados oficiais, e próximo de 300, de acordo com os números não-oficiais. O episódio incitou uma atitude de oposição ainda mais crítica em setores da sociedade civil muitos analistas concordam em dizer que vários grupos revolucionarios mexicanos nasceram como decorrência direta do massacre ${ }^{47}-$, o que, por sua vez, deu ensejo ao início do período conhecido como "Guerra Suja", em que o governo do PRI deu encaminhamento a um conjunto de medidas para reprimir e dissolver os movimentos de contestação política e armada.

Se Rafael Guillén veio ao mundo em 1957, o futuro Subcomandante Marcos parece ser fruto justamente dos acontecimentos de $1968 .{ }^{48}$ Um líder estudantil à época, Eduardo Valle, havia vaticinado que o massacre promovido pelas tropas do governo central provocaria um efeito indiscutível nas crianças, alertando que "o governo deste país terá que ficar muito precavido com aqueles que tinham 10 ou 15 anos em $1968 .$. eles sempre se lembrarão dos ataques, dos assassinatos de seus irmãos". 49 A "profecia" de Valle parece, pois, ter valido para o caso do Subcomandante; exatamente trinta anos depois, em 2 de outubro de 1998, Marcos escreveria o comunicado "Trinta Anos Depois, A Luta Continua", em homenagem às vítimas de Tlatelolco, em que exalta a "geração de dignidade de 68" e explicita como o evento de havia impactado em sua formação crítica. Antes, em entrevista ao La Jornada de fevereiro de 1994, quando perguntado se é produto de 68, Marcos se coloca como “pós-68”, mas tributário de tudo que se seguiu a partir daqueles anos. ${ }^{50}$

Nesta época de sua vida, teve contato pela primeira vez com a obra literária que iria influenciar marcadamente toda a vida de Rafael Guillén, qual seja, Dom Quixote de la Mancha, do espanhol Miguel de Cervantes. Como pudemos perceber pela análise de várias fontes, o personagem principal da obra parece ocupar lugar central no imaginário do Subcomandante, fazendo-se referência obrigatória em diversos comunicados, entrevistas e declarações. Rafael, inclusive, chegou a levar o livro a Chiapas e afirmaria, em entrevista, estar ao seu lado (como espécie de Bíblia) sempre que possível,

\footnotetext{
${ }^{47}$ MENTINIS, Mihalis. Zapatistas: The Chiapas Revolt and What It Means for Radical Politics. London: Pluto Press, 2006, p.2.

48 STAVANS, Ilan. “Unmasking Marcos”. Transition, 1996. In: HAYDEN, Tom. The Zapatista Reader. New York: Nation Books, 2002, p.392.

${ }^{49}$ KRAUZE, Enrique. Mexico: Biography of Power. NY: Harper Collins, 1997.

${ }^{50}$ Rafael tinha apenas 11 anos em 1968.
} 
classificando-o como "o melhor livro de teoria política já escrito". 51 A própria criação ficcional dos escritos do Subcomandante Marcos - que se configura como espécie de alterego -, qual seja, Don Durito, o escaravelho a quem Marcos dá um pouco de tabaco em troca de ensinamentos (e de quem depois vira escudeiro), é uma clara referência ao mundo quixotesco.

Pudemos observar, ainda, seu percurso no ginásio e no colegial, atentando também para características que seriam observáveis nas performances do Subcomandante; depoimentos de professores do ginásio (que ele realizou entre 1970 e 1973) comentando sobre seu lado criativo e irreverente na execução de tarefas escolares, bem como relatos de professores do ensino médio insinuando um ímpeto pragmático do jovem Rafael, ao buscar envolvimento em trabalhos comunitários, como atividade extra-curricular.

Além disso, tivemos a oportunidade de descobrir que o teatro mostrou-se tema de grande interesse de Rafael Guillén desde aquela época (ele apreciava o dramaturgo e escritor irlandês Samuel Beckett desde então) - a teatralidade constituiu-se como elemento central nas atitudes do Subcomandante Marcos, ${ }^{52}$ o que será abordado mais adiante) -, participando de peças como protagonista, como no caso de "El Tuerto es Rey" da autoria de Carlos Fuentes, ou mesmo interpretando trechos de poemas nas aulas de literatura.

O desenvolvimento da retórica, aliás, obteve grande ênfase na formação pedagógica de Rafael, sendo estimulado no seio familiar e, de mesmo modo, pelo professores jesuítas do Instituto Cultural de Tampico, onde estudou entre 1974 e 1976. Observamos em vários relatos de professores e colegas da época de colégio que Rafael era considerado um grande orador e, por ocasião de debates (espontâneos ou provocados como atividade de classe pelos professores), sempre lançava mão dos melhores argumentos. É nessa esteira, inclusive, que reside o cerne das divergências sobre a personalidade de Rafael/Marcos, tanto para colegas de colégio, quanto para futuros companheiros da guerrilha: enquanto uns dizem que, ao debater, ele seria uma pessoa aberta e tolerante, outros afirmam que era fechado às suas ideias e "dono-darazão". Muito disso está em discussão para examinar seu papel na formulação do ideário

\footnotetext{
${ }^{51}$ GARCIA MARQUEZ e POMBO, 2001, p.79.

52 Sobre o aspecto teatral do Subcomandante, Cf. GOMEZ-PEÑA (1995) "Subcommander of Performance"e HASS (2001) "Marcos: Maestro de la Teatralidad".
} 
zapatista e na condução dos rumos do EZLN, na medida em que aparentou, de maneira geral, ter sido aberto a ouvir mais do que a impor; de outro lado, porém, alguns se contrapõem afirmando que, ao fim e ao cabo, eram suas vontades que prevaleciam.

Identificamos, também, que Rafael passou, a partir dessa época, a cultivar uma admiração crescente pela figura de Ernesto Che Guevara, pelo romantismo que a figura do heroi guerrilheiro transmitia. Em várias fases da juventude, Rafael parecia buscar emular Che, fazendo, por exemplo, uso de uma boina como adereço cotidiano, bem como iniciando um costume que iria caracterizar sua imagem como Subcomandante Marcos, qual seja, o ato de fumar cachimbo - ele teria visto Che fumando cachimbo (e não os famosos charutos) em fotografias. ${ }^{53}$ Sobre esse hábito, Elia Ester, ex-namorada de seu irmão Carlos, atenta, em entrevista para revista Proceso, de agosto de 1995, que no começo Rafael sequer os fumava, apenas andava com o cachimbo no bolso, o colocava na boca, de modo que acabava aparentando ser um traço de afetação.

Outra característica que se mostrou perceptível em diversas fontes foi a disposição de Rafael em fazer caridade, manifestando-se solidário com os sofrimentos alheios. O depoimento do monge Refúgio Marín, professor de Rafael, à revista Proceso em agosto de 1995, ilustra esse aspecto presente na postura de Rafael, dizendo que

ele sempre ajudou seus compañeros, ele sempre dividiu o que ele tinha, sempre, sempre, sempre. Ele guardava um dinheiro no bolso e se algum compañero não tivesse dinheiro, ele comprava um bolo ou algo pra beber. Ele era um bom compañero. Ele sempre ajudou os necessitados.

Na mesma entrevista, Marín, faz uma avaliação de como se sentia em ter contribuído para a formação do Subcomandante Marcos, com as seguintes palavras:

Estou contente com meu antigo pupilo, admiro seu valor heroico, seus objetivos são nobres e eu os respeito e admiro. É ótimo que ele se preocupe com os indígenas. Hoje em dia não há ninguém como ele no México. O governo não só é ruim para os indígenas, é ruim para todos os cidadãos, mas nós não temos a coragem que Rafael tem.

53 Cf. CASTAÑEDA, 1997, p.192. Che teria exaltado os benefícios de se fumar cachimbo aos revolucionários, sobretudo em suas missões no Congo e na Bolívia, das quais Marcos teria visto fotos do guerrilheiro fazendo uso do cachimbo. 
Só discordo de seus métodos, a guerra, mas talvez as circunstâncias ditem isso. Se eles têm falado e ninguém os escuta... só Deus pode julgá-lo (tradução nossa). ${ }^{54}$

Formado, então, a partir desse substrato (intelectual e político) crítico latinoamericano, Rafael disse a Rubén Núñez de Cáceres, seu professor de colégio: "agora estou indo fazer a revolução", 55 em referência ao fato de estar indo à capital nacional para iniciar um novo ciclo em sua vida, ao começar o curso de Filosofia na Universidade Nacional Autônoma do México, a UNAM. ${ }^{56}$

$*$
"Até agora os filósofos se limitaram a interpretar o mundo.
Cabe-lhes agora transformá-lo."
(Karl Marx, “Teses sobre Feuerbach")

Rafael Guillén mudou-se para a Cidade do México em 1977, e vai morar com seu irmão Carlos, que também estudava na UNAM. Segundo relato do próprio Carlos, Rafael terminou o curso de Filosofia, na Faculdade de Filosofia e Letras, em apenas seis meses e não nos dez estipulados. ${ }^{57}$ É interessante apontar que, no ano de 1994, desde os primeiros meses da aparição pública do Subcomandante Marcos, ele chegou a insinuar ser aluno egresso da instituição (em comunicado em que fez um relato detalhado do campus e da rotina na universidade) - embora em outros momentos negue tal fato, como parte de sua postura recorrente de dissimular seu próprio passado.

\footnotetext{
54 "I'm happy with my former pupil, I admire his heroic valor, his aims are noble and I respect and admire them. It is great that he cares about the indigenous. In Mexico today there is no one like him. The government is not only bad to the indigenous, it is bad to all the citizens, but we don't have the courage that Rafael has. The only thing I disagree with is his methods, the war, but perhaps the circumstances dictate this. If they have spoken and no one listens... only God is able to judge him".

${ }^{55}$ GRANGE e RICO, 1998, p.73.

${ }^{56}$ Antes, porém, de começar os estudos na UNAM, Rafael ajudou seu pai Alfonso na loja de móveis da família (fez entregas de produtos e explorou seu lado criativo criando slogans como "Mueblerías Guillén, las de crédito humanitario") e, ainda, teve a oportunidade de viajar a turismo com a família para a França e a Espanha.

${ }^{57}$ Ibidem, p.75.
} 
Pudemos observar, no período em que Rafael estudou na UNAM, um crescente envolvimento com a política estudantil, ${ }^{58}$ a partir do contato com estudantes de orientação trotskyista, embora ele mesmo nunca tivesse se sentido inteiramente membro desses grupos, segundo relatos de colegas de UNAM: participou de atividades de greve, confecção de pôsteres e cartazes ${ }^{59}$ e atividades de extensão universitária. Do ponto de vista acadêmico, aproximou-se da filosofia francesa do século XX, como Althusser (o althusserianismo era pensamento predominante na Faculdade de Filosofia e Letras da UNAM à época), Derrida e Foucault. Como afirma Pablo Ortellado, ${ }^{60}$ a heterodoxia da formação de Rafael pode ter contribuído substancialmente como raiz para que o programa zapatista contemplasse já em 1992 uma aplicação criativa e renovadora do marxismo. Alberto Híjar, seu professor, afirma, entretanto, que não há nada do Subcomandante Marcos no Guillén althusseriano, ${ }^{61}$ e que suas teses e convicções não apontavam para o líder revolucionário que surgiria.

Muito influenciado pelos autores mencionados, Rafael Guillén escreveu um trabalho de conclusão de curso entitulado "Filosofía y Educación: Práticas discursivas y práticas ideológicas. Sujeto y cambio históricos en libros de texto oficiales para la educación primaria en México", orientado por Cesáreo Morales, que viria a ser assessor do ministro e presidenciável assassinado Donaldo Colosio e deputado pelo PRI (19911994). No trabalho de 121 páginas, várias das metáforas e temas usados com frequência nos comunicados do Subcomandante Marcos (como formigas, sexo, entre outras) estão presentes. Em 1980, Rafael recebeu das mãos do Presidente José López Portillo o prêmio Gabino Barreda, nome em homenagem ao famoso positivista mexicano, que era concedido anualmente ao melhor estudante do país, o que certamente demonstrava sua distinção acadêmica. ${ }^{62} \mathrm{O}$ trabalho, que tinha como objetivo geral pensar a educação enquanto aparelho ideológico de Estado, seria discutido na revista Proceso, $\mathrm{n}^{\circ}$ 954, de 13 de fevereiro de 1995, logo após o desmascaramento do Subcomandante Marcos.

\footnotetext{
${ }^{58}$ Muito embora, como enfatiza Henck (2007), Rafael tivesse pouca influência na condução dos rumos da política do movimento estudantil na UNAM, uma vez que sua atuação se restingia a pequenos círculos políticos, não liderando, portanto, o conjunto dos estudantes.

${ }^{59}$ Com frases como “Muera el Mal Gobierno!", expressão tão típica do zapatismo, embora não inventada por ele.

${ }^{60}$ In: FIGUEIREDO, 2006, p.XIV.

${ }^{61}$ GRANGE e RICO, 1998, p.93.

${ }^{62} \mathrm{O}$ já referido professor Híjar, membro da banca avaliadora, qualifica seu trabalho como brilhante, assim como as respostas na arguição oral (CORRO, 1995, p.26).
} 
Guillén era considerado eloquente nas discussões políticas e até mesmo irreverente em relação aos outros estudantes de filosofia, ${ }^{63}$ os quais, por vezes, tendiam a forjar um comportamento mais ortodoxo, a fim de reforçar um ethos de seriedade que se manifestava, por exemplo, pelo distanciamento com o mundo da política - tipos a quem ele denominou, no próprio trabalho de conclusão de curso, de "marxistas de mesa de café". ${ }^{64}$ No período de estudos na UNAM, Guillén namorou Rocío Casariego (militante próxima a ele e que iria à Nicarágua, no início dos anos 80 , com o nome de Mercedes), a quem ele chegou a apresentar à família; em entrevista, ela também fala bem de sua oratória (mas afirmando que, afinal, não era nada excepcional) e destaca o fato de Guillén ser bastante machista, como a maioria dos outros mexicanos do norte. ${ }^{65}$ É na UNAM, também, que aprendeu outros idiomas, como francês, italiano e português - fato que chamaria a atenção dos turistas que estavam em Chiapas no fatídico $1^{\circ}$ de janeiro de 1994.

É fundamental destacar que foi neste período do fim dos anos 70 que Rafael encontrou a perspectiva revolucionária por meio da ação em guerrilhas. A partir da recomendação de um professor (várias fontes apontam que seja Alberto Híjar), ele passou a lecionar, por quatro anos, na Universidade Autônoma Metropolitana, a UAM, fundada em 1974 e famosa pela reputação de abrigar radicais de esquerda, local onde se vivia uma atmosfera de "efervescência permanente"66. Os grupos guerrilheiros das Forças de Libertação Nacional, as FLN, tinham muitos membros na UNAM e sobretudo na UAM, de modo que a historiografia não consegue afirmar peremptoriamente qual das duas universidades teria sido o canal definitivo para Rafael ingressar na corrente sulista das FLN, em Chiapas.

\footnotetext{
${ }^{63}$ OPPENHEIMER, Andres. Bordering in Chaos. Boston: Little Brown, 1996, p.250.

${ }^{64}$ Idem, pp.251-252.

${ }^{65}$ GRANGE e RICO, 1998, pp.87.88.

${ }^{66} \mathrm{O}$ expressão é de Velasco Ugalde, um dos líderes políticos na UAM à época. Para ele, a UAM foi: "uma experiência absolutamente inédita na história do sistema universitário mexicano, um reduto de ideias conflitantes, iniciativas de vanguarda, excessos entusiasmados e importantes inovações; um nó de contradições; a manifestação da esquizofrenia política mexicana que escapou de forma efêmera ao controle daqueles que a promoveram; uma tentativa formidável de redefinir a universidade, sua consciência, tanto sua própria quanto de sua relação com a sociedade. Era tudo isso e muito mais" (MERGIER, 1995, p.14, tradução nossa). No original, "an experience absolutely unheard of in the history of the mexican university system, a hotbed of conflicting ideas, vanguardist initiatives, enthusiastic excesses, and important innovations; a knot of contradictions; a manifestation of the mexican political schizophrenia that ephemerally escaped from the control of its promoters; a formidable attempt at redefining the university, its consciousness, both its own and in its relation to society.it was all this and much more".
} 
A carreira Guillén como professor na UAM começou em 16 de janeiro de 1979 e foi até o dia 3 de fevereiro de 1984. Lecionou no Departamento de Ciências e Artes para Design, no campus Xochimilco (os outros dois campi eram Azcapotzalco e Iztapalapa), onde os professores eram famosos por serem os mais heterodoxos e radicais. A filosofia pedagógica da instituição valorizava a interdisciplinariedade e o contato permanente com sociedade, dando grande relevo à dimensão prática, tomada como elemento indissociável da teoria.

O contexto das vitórias sandinistas na Nicarágua, em 1979, animava Rafael em seu primeiro ano como professor. Segundo os depoimentos de ex-alunos (a maioria documentados na revista Proceso e nas obras de Grange e Rico, e de Henck), o Professor Guillén recomendava leituras de Foucault, Althusser, Poulantzas, Matelard, Marcuse, Mao e Marx. Testemunhos de ex-alunos e assistentes da UAM caracterizam o professor Guillén como alguém de popularidade entre os alunos, tendo ganhado os apelidos de Guillomas e também de "Patas Verdes", por usar só um tênis de cor verde (o testemunho da ex-namorada Rocío Casariego aponta para a simplicidade e desapego de Rafael: diz que, nesta época, ele tinha um par de calças e três camisetas no armário). Para prender a atenção dos alunos e estimular o debate, fazia costumeiro uso da ironia e lançava mão de piadas - um showman, em resumo ${ }^{67}$-, características também observáveis nos futuros comunicados do Subcomandante Marcos. De todo modo, quando indagados sobre a relação entre o professor Guillén e o Subcomandante Marcos, os alunos da época da UAM não conseguem exatamente provar que fossem a mesma pessoa, embora pudessem apontar vários elementos de semelhança. ${ }^{68}$

Quanto ao seu ingresso em atividades de guerrilha, Rafael foi gradativamente construindo laços com as FLN. Tello Díaz sugere que o professor Híjar, por ter envolvimento com as FLN, teria colocado Rafael em contato direto com o movimento, indicando seu aluno para dar aulas na UAM, onde havia vários membros. Junto de tais forças revolucionárias, cuja célula original era proveniente da Universidade de Nuevo León (o grupo apresentava ativismo sobretudo em jovens universitários), Rafael - que, nesta época, atendia pelo codinome de Zacarías - visitou fronts das FLN na Sierra Tarahumara em Chihuahua, em Veracruz e na capital do país. Viajou, ainda, a Cuba

\footnotetext{
${ }^{67}$ HENCK, 2007, pp.46-48.

${ }^{68}$ Uma outra "pista" - que a jornalista Alma Guillermoprieto recorre - é o fato de o anfiteatro zapatista em Chiapas ser decorado com pinturas em mural com influências do realismo socialista e do surrealismo, tal como fizeram na UAM, à época em que Rafael lá trabalhava.
} 
(segundo afirmam Grange e Rico) e à Nicarágua, bem como fez algumas viagens à porção meridional do México, em Chiapas, local para onde, como sabemos, tomou a decisão de se estabelecer definitivamente a partir de $1984 .{ }^{69}$

Ao partir para Chiapas sem declarar à família, Rafael deixou para trás os poucos bens que tinha. Nas palavras dele: "Deixei para trás, na cidade, um bilhete de metrô, uma pilha de livros, um lápis quebrado, um caderno cheio de poemas... Não me lembro de ter deixado mais nada... Nem discos, nem fitas cassetes". ${ }^{70}$ Uma vez que partiu, regressava somente em datas especiais - épocas natalinas, segundo lembra o sobrinho António Méndez Guillén, alegando que trabalhava fora ${ }^{71}$ - e suas desaparições passaram a ser cada vez maiores. Sua mãe, Socorro Vicente, ${ }^{72}$ se queixava do fato de que Rafael "ia e voltava, uma ou outra vez. Nunca soubemos realmente onde estava" 73 E progressivamente deixaram de receber notícias dele:

As poucas cartas que escreveu triangulava, enviando-as primeiro a outra pessoa que, por sua vez, encaminhava aos senhores Guillén. Uma delas começava: "Querido pai/Quijote, às vezes também Sancho [...], querida mãe/Sancho, às vezes também Quijote", e continuava neste estilo. "Aproveitava qualquer situação para fazer literatura", disse seu pai "foi uma época muito estranha dele; às vezes não nos dizia nada para não nos comprometer". Dizia estar na França e ter uma filha, trabalhar como tradutor simultâneo na Bélgica e ter dado uma palestra na Nicarágua, referindo-se sem dúvida à que ministrou junto aos outros brigadistas quando foi professor de desenho gráfico na UAM. (...) Em março de 1992, na última vez que esteve em Tampico, entre muitos comentários irracionais, admitiu morar em Tuxtle Gutiérrez e lá ter uma miscelânea de nome Mi Abuela. ${ }^{74}$

\footnotetext{
${ }^{69}$ HENCK, 2007, p.50. De qualquer maneira, segundo Henck (2007) o período entre 1982 e 1984 é onde há maiores lacunas no conhecimento para compreensão do processo de como Rafael vai acabar se transformando em Marcos. Pouco se sabe se, de fato, teria recebido durante esse tempo algum tipo de treinamento militar na Nicarágua sandinista, por exemplo. Neste ponto, em específico, há muitas divergências entre as fontes e o próprio Marcos é evasivo em entrevista a Le Bot (1997) quando fala da ida ao país. Os residentes do povoado nicaraguense de San Juan de Río Coco, entretanto, afirmaram o reconhecer em fotos publicadas na revista Proceso, dizendo que era conhecido entre eles como "o mexicano" (ESPINOSA, 1995) - e apontaram um elemento característico dos hábitos de Rafael, qual seja, o fato de não beber álcool (HENCK, 2007).

70 "I left behind in the city, a metro ticket, a pile of books, a broken pencil, a notebook full of poems... I don't recall having left anything else... no music records nor tape cassettes". (DURÁN DE HUERTA, 1994, pp.14-15).

${ }^{71}$ ESPINOSA, 1995.

${ }^{72}$ Falecida no ano de 2009.

${ }^{73}$ Idem, 1995.

74 “Las pocas cartas que escribió las triangulaba, enviándolas primero a otra persona que a su vez las turnaba a los señores Guillén. Una de ellas comenzaba: "Querido padre/Quijote, a veces también Sancho
} 
Com o desmascaramento do Subcomandante Marcos, que será abordado mais adiante, a familia passou a ser massivamente procurada por jornalistas. Seu pai, Alfonso Guillén ${ }^{75}$, afirmaria que Rafael agora publicamente conhecido como o Subcomandante Marcos, "restaurou em mim a alegria de viver, minha segunda juventude". ${ }^{76}$

[...], querida madre/Sancho, a veces también Quijote", y seguía por el estilo. "Aprovechaba cualquier situación para hacer literatura", dice su padre, "fue una época muy rara de él; a lo mejor no nos decía nada para no comprometernos." Decía estar en Francia y tener una hija, trabajar como traductor simultáneo en Bélgica y haber dado una cátedra en Nicaragua refiriéndose sin duda a la que impartió junto a otros brigadistas cuando fue maestro de diseño gráfico en la UAM. (...) En marzo de $1992^{74}$, la última vez que estuvo en Tampico, entre muchos comentarios disparatados admitió residir en Tuxtla Gutiérrez y poseer allí una miscelánea de nombre Mi Abuela (SOLARIS, 1996).

${ }^{75}$ Falecido em 2005.

${ }^{76}$ GRANGE e RICO, 1998, p.68. 


\section{A Morte e a Vida de Marcos}

"O aventureiro é aquele que faz acontecerem as aventuras, mais do que aquele a quem as aventuras acontecem"

(Guy-Ernest Debord, Internacional Letrista, 1954).

Nesta parte do trabalho, pesquisamos o período histórico compreendido entre 1984 - ano em que Marcos ingressa no Exército Zapatista de Libertação Nacional, em Chiapas - e o final de 1993, no momento imediatamente anterior a eclosão da revolta zapatista. O estudo desse período é fundamental para o entendimento de como se forma o EZLN (ao indentificarmos como e porquê ocorrem transformações em seu projeto) a partir da perspectiva da militância de esquerda no Estado. ${ }^{77}$ Nesse sentido, busca-se compreender os desdobramentos de sua atuação, a fim de identificar os fatores que, conjugados, vão culminar justamente no abandono de certos princípios de um marxismo mais ortodoxo. E o foco residiu em investigar qual o papel de Marcos em todo esse processo, assentando alguns pressupostos para que pudéssemos compreender o significado que sua figura adquire depois da exposição pública do movimento.

Nessa esteira, mostrou-se relevante estudar o contexto sócio-econômico de Chiapas, para compreensão mais ampla do cenário em que o movimento se consolida. De mesmo modo, procuramos entender a abertura das políticas de neoliberalização no México, a partir do governo de Miguel de la Madrid, atentando, sobretudo, para os seus efeitos nas comunidades chiapanecas - e como isso se reflete nas percepções e estratégias dos membros do movimento zapatista. O coroamento desse processo vai se realizar na implementação do NAFTA, elaborado sob o governo de Carlos Salinas de Gortari, em um contexto mundial de proclamação do fim das utopias. Utopia que é tema central que o zapatismo vai resgatar; discutiremos, assim, como a utopia zapatista é gestada justamente dentro desse "período em que os acontecimentos mundiais e o zeitgeist atuam contra o espírito utópico". 78

\footnotetext{
${ }^{77}$ Embora examinar em conjunto as contribuições das ações pastorais dos padres progressistas (tributários da teologia da Libertação) e da própria cultura indígena na formação da política zapatista, daremos enfoque à atuação da militância guerrilheira, observando a questão a partir desse ângulo, naturalmente, considerando nossos objetivo central, dando destaque especial ao papel de Marcos nesse processo.

${ }^{78}$ JACOBY, Russel. O Fim da Utopia: política e cultura na era da apatia. Rio de Janeiro: Record, 2001, p.234.
} 
O Estado de Chiapas, que passou a fazer parte do México em 1824 (até então pertencia à Capitania Geral da Guatemala), é habitado contemporaneamente por cerca de 4 milhões e 800 mil pessoas e caracteriza-se como uma das regiões mais pobres do país, ao lado dos Estados de Oaxaca e Guerrero. ${ }^{79}$ Seu território encontra-se entre as planícies de Tabasco ao norte e o Oceano Pacifico ao sul; limitado pelos rios Usumacinta e Suchiate e pela cordilheira dos montes Cuchumatanes ao leste e pelos estados de Oaxaca e Veracruz a oeste. Aproximadamente um quarto da população local fala alguma língua indígena, o que faz com que o Estado se apresente como o que tem mais habitantes que não falam espanhol no país.

Segundo Emilio Zebadúa, ${ }^{80}$ a história de Chiapas é, em alguma medida, isolada do resto da história do México, ainda que não se desconsidere os processos mais amplos que modelaram a história da nação em seu conjunto. No plesbiscito de 1824, as elites chiapanecas decidiram pela integração ao México e separação da Capitania Geral da Guatemala sob o lema "más vale ser cola de león que cabeza de ratón" (na tradução ao português: "mais vale ser cauda de leão que cabeça de rato"), emblemático da percepção de que ao se transformarem em parte do conjunto da nação mexicana, partem de uma posição relativamente desfavorável. De fato, a região apresenta idiossincasias do ponto de vista da formação étnica, social e econômica, em um trama complexa de relações fundadas em desiguldades estruturais. Como nos lembra Sebastião Vargas,

O historiador mexicano Antonio García de León compara a história de Chiapas, com suas desiguais e descontínuas situações econômicas, à pele de um imenso jaguar: com manchas irregulares, onde se combinam partes claras, de uma maior penetração das relações capitalistas, com as partes escuras e profundas que vêm de um passado imemorial $^{81}$. Um dos traços mais notáveis dessa história regional é a resistência indígena e camponesa que caracterizou, por séculos, o tortuoso desenrolar dos acontecimentos deste estado que sempre foi considerado uma das regiões mais pobres

\footnotetext{
${ }^{79}$ A título de ilustração, Chiapas possui um Índice de Desenvolvimento Humano (IDH) de 0,646. Para comparar, é equivalente ao do Uzbequistão e ao da Síria; o índice do Distrito Federal, Estado mais rico do país, é de 0,922. O IDH de 2013 do México é de 0,775.

80 ZEBADÚA, Emilio. Breve Historia De Chiapas. Fondo de Cultura Economica USA, 1999. A formação acadêmica de Zebadúa como historiador é muito tributária a Womack Jr., referência também bastante utilizada nesta dissertação.
}

${ }^{81}$ GARCÍA DE LEON, 2003, p.11. 
do país. A exploração, a discriminação e os 'maus tratos' que sofreram os camponeses e indígenas sempre estiveram muito presentes no cotidiano da sociedade chiapaneca. Isto permitiu que desde o princípio suas demandas não se restringissem somente a recuperação de suas terras, estendendo-se para outros elementos da estrutura de poder: monopólio de mercados; questões religiosas e paroquiais; impostos e contribuições pessoais; racismo; pouca remuneração pelo trabalho; falta de representação governamental. ${ }^{82}$

Sobre os contrastes mesmo dentro de Chiapas, é ilustrativo caso da fazenda Fincanbar (em exemplo trazido pelo próprio García de León), a qual tinha em suas instalações uma pintura de Andy Wahrol ao mesmo tempo em que mantinha ali trabalho semi-escravo. No que se refere ao racismo contra indígenas, pode-se destacar que é um dos resquícios persistentes do sistema colonial ${ }^{83}$ : até a data do levante zapatista, era comum se ver indígenas saírem das calçadas ou levantarem de assentos em ônibus para brancos passarem ou sentarem. E, não raro, isso ocorria por iniciativa própria. ${ }^{84}$

Os índices do Estado de acordo com o XI Censo General de Población y Vivienda, de 1990, denunciam a situação precária em que se encontrava Chiapas às vésparas da insurreição do EZLN: todos os indicadores ficaram abaixo da média nacional. Nos anos 90, de um total de 111 municípios, 37 apresentaram um grau muito elevado de marginalização, sendo a maioria nas regiões de Los Altos e na Selva, locais onde se encontram as cidades que zapatistas vão ocupar. Chiapas, nesse censo, teve a mais alta taxa de mortalidade (devido principalmente a desnutrição, anemia, infecções intestinais e respiratórias, tuberculose e afecções perinatais, contando com apenas um médico para cada 1130 habitantes) e, ainda assim, a taxa de crescimento populacional anual superou a média do país - então com 3 milhões e 200 mil pessoas, a taxa aumentou, desde 1970, a 3,64\% em comparação a 2,64\% do resto do país. Os dados de anafalbetismo e evasão escolar mostraram-se igualmente altos. Segundo tal censo, 36,9\% da população economicamente ativa recebia mais de um salário mínimo, em comparação com 69\%2\% da média nacional. Em 1994, ano do levante zapatista, o Estado tinha apenas $20 \%$ de suas estradas pavimentadas, poucos serviços de telefonia e eletricidade. A maioria da população vivia em pequenas comunidades, sendo que

\footnotetext{
${ }^{82}$ VARGAS, 2007, p.188.

${ }^{83}$ MONTEMAYOR, Carlos. Chiapas, La Rebélion Indígena de México. Madrid: Espasa, 1998.

${ }^{84}$ FUSER, 1995, p.50.
} 
apenas um quarto dos habitantes vivia em comunidades com mais de 15.000 pessoas ${ }^{85}$. O PIB per capita de Chiapas na época era de US\$ 1.466 contra US\$ 8.129 no Distrito Federal.

Ainda segundo o censo, $58 \%$ da população ganhava a vida com trabalhos no campo, principalmente pelo cultivo de milho, feijão, banana, melão, manga e cana-deaçúcar, bem como pela criação de gado. No conjunto, as riquezas naturais do Estado sempre atraíram investimentos públicos e privados para exploração da floresta, das águas e do subsolo. É notável, nos anos 90, a exploração de madeira, por exemplo, que tem a maior participação industrial relativa dentro das existentes no estado. Outras riquezas que contribuem para a economia mexicana à época eram o petróleo (explorado pela empresa Petroleos Mexicanos), com 6,5\% do total nacional, gás natural, com 23\%, e geração de eletricidade (administrada pela Comissión Federal de Eletricidad nas centrais hidrelétricas de Malpaso, La Angostura, Chicoasén e Peñitas), com 8\% (e quase $50 \%$ da energia de matriz hidrelétrica). No marco do NAFTA, companhias transnacionais como Simpson, International Paper e Lousiana Pacific interessaram-se em investir na produção de papel proveniente da exploração de Chiapas. ${ }^{86}$

Vários autores enfatizam que a reforma agrária começou tarde em Chiapas, em relação ao resto do país, mas intensificou-se sobretudo entre as décadas de 1950 e 1970. Nesses anos, se comparado às décadas anteriores, o Estado se desenvolveu significativamente: o governo central ampliou o investimento em infraestrutura energética e buscou estimular o desenvolvimento em outras áreas de Chiapas. Nos anos 70, os governos de Luís Etcheverría Alvaréz e José Lopez Portillo fizeram alguns esforços para melhorar a condição dos índios em Chiapas. O governo federal criou o Programa de Desenvolvimento Socioeconômico dos Altos de Chiapas (PRODESCH) em 1972. Nesse contexto, o crescimento demográfico no Estado tornou inviável a manutenção de milhares de famílias campesinas e o governo duplica o número de ejidatários ${ }^{87}$ e passou a investir em programas sociais que buscavam diminuir a miséria fortemente presente na região, a fim de evitar, sobretudo, a eclosão de conflitos

\footnotetext{
85 Os municípios com maior população, segundo o censo, eram: a capital Tuxla Gutiérrez, Tapachula, Ocosingo, San Cristóbal de las Casas, Las Margaritas, Comitán, Villaflores, Tonalá, Chilón e Palenque algumas são tomadas com a insurreição zapatista no dia $1^{\circ}$ de janeiro de 1994.

${ }^{86}$ ZEBADÚA, 1999, p.165.

${ }^{87}$ Os ejidos são as propriedades comunais que, até 1992, não podiam ser vendidas ao capital privado, permitindo a reprodução dos costumes e tradições indígenas dentro deles.
} 
agrários. É a partir de então que começou o processo de emigração massiva da região de Los Altos à região de Las Cañadas na Selva Lacandona. De modo que, no ano de 1972, o governo outorgou metade das terras da Selva Lacandona a 66 famílias da etnia dos lacandones.

Muitos historiadores consideram o ano de 1974 como pivotal na história regional de Chiapas $^{88}$ : no mês de outubro daquele ano, foi organizado o Congresso Indígena, em comemoração aos 500 anos do nascimento do Frei Bartolomeu de las Casas. O congresso recebeu mais de dois mil delegados na cidade de San Cristóbal de las Casas e deu início a um forte processo de politização das populações locais a partir do contato com os párocos católicos influenciados pelo II Concílio Vaticano (1963-1968) e pela Teologia da Libertação, que cultivavam outro tipo de relação com os povos indígenas. Com isso, os líderes comunitários das etnias presentes em Chiapas tiveram a possibilidade de articular formas novas de resistência. ${ }^{89}$

A década de 1980 assistiu a tensões sociais diversas por conta da questão agrária, canalizadas, por vezes, em violência e ocupação de terras. Junto a isso, programas de assistência social foram desenvolvidos no Estado pelo governo federal. De todo modo, a crise econômica nacional daqueles anos afetaria as finanças públicas e o governo diminuiria programas de apoio ao campo, agora com menos créditos e subsídios (a título de ilustração, em 1989, o preço internacional do café caiu pela metade e afetou pequenos produtores drasticamente). Com efeito, a pobreza no país cresceu de 32,1 milhões ou 45\% da população em 1981 para 41,3 milhões ou $51 \%$ em 1987. ${ }^{90}$ Em resumo, seguindo Zebadúa, “algumas de suas características demográficas, econômicas e sociais colocam o Estado abaixo nos índices de desenvolvimento e têm contribuído para criar condições políticas e culturais de excepcionalidade". ${ }^{91}$

Contudo, o Subcomandante Daniel, um dos atores políticos do EZLN, observa que a escolha de Chiapas não teria sido pelo potencial revolucionário - proporcionado pela situação de pobreza e pela estrutura politíca estabelecida pelos padres -, mas sim pela geografia propícia: o local inacessível facilitaria treinamentos militares. Marcos em

\footnotetext{
${ }^{88}$ HIGGINS, Nicholas P. Understanding the Chiapas Rebellion: Modernist Visions and the Invisible Indian. Texas: University of Texas Press, 2004, p.145.

${ }^{89}$ As principais etnias são tzeltales, tzotziles, choles, tojolobales, mams e zoques.

${ }^{90}$ CASTAÑNDA, 1994, p. 257.

${ }^{91}$ Idem, p.13.
} 
entrevista a McCaughan ${ }^{92}$ reafirma que necessitavam de condições geográficas para isolamento e segurança, em lugares em que os guerrilheiros não pudessem ser detecetados facilmente. Ainda, do ponto de vista gerográfico, o Estado tem vários cursos de água navegáveis que serviriam como canais para facilitar a movimentacão e circulação de informações entre os guerrilheiros, a saber, os rios Negro, Lacanjah, Lacantún, Santo Domingo e Jataté. Além disso, a proximidade com a Guatemala também ajudava, na medida em que o Exército mexicano não poderia ir além de suas fronteiras em uma eventual busca dos guerrilheiros, configurando-se como fácil rota de escape.

Ainda, há um outro ponto importante a ser destacado: alguns analistas concordam em afirmar a ausência da Revolução Mexicana do começo do século XX em partes do sudeste do país. Mesmo o presidente Miguel de la Madrid (1982-1988) havia declarado, no ano de 1983, que o processo revolucionário não havia completado sua missão em Chiapas e que em alguns lugares do Estado havia passado desconhecida; ${ }^{93}$ o próprio Subcomandante Marcos diz, em dezembro de 1994, querer fazer chegar a revolução que nunca veio ao sudeste.

O governo de Miguel de la Madrid Hurtado marcou uma baliza na história do PRI, na medida em que abandonou abertamente o elemento revolucionário tão presente na retórica do partido; De la Madrid, eleito em 1982 para a presidência da República, havia sido Secretário de Planejamento e Orçamento (Secretaría de Programación y Presupuesto) do governo Portillo. Desde o fim da década de 1970, defendia a implementação de reformas macroeconômicas no sentido da liberalização da economia - o que ele coloca em prática logo quando assume, no contexto da crise da dívida mexicana. Seguindo o receituário adotado na ditadura de Augusto Pinochet no Chile, De la Madrid buscou reduzir o papel do Estado na economia, restringiu a política fiscal e monetária, desvalorizou o câmbio, privatizou indústrias estratégicas e começou a

\footnotetext{
92 McCAUGHAN, Michael. "King of the Jungle". Irish Times, August 5, 1999. In: HAYDEN, 2002, p.57.

93 BENJAMIN, Thomas. A Rich Land, a Poor People: Politics and Society in Modern Chiapas. Albuquerque: University of New Mexico Press. 1996.
} 
empreender reformas constitucionais para facilitar a abertura comercial do país, ${ }^{94}$ instrumentos para colocar em prática sua agenda neoliberal. Como aponta Barkin:

Quatro componentes têm guiado a política econômica mexicana: um alto grau de participação estatal na economia; uma estratégia de 'desenvolvimento estável' que tentou manter os preços, as taxas de juros e a taxa de câmbio sob controle; a proteção da indústria nacional por meio de altas barreiras tarifárias e não-tarifárias ao comércio e aos investimentos internacionais; e uma tentativa de promover um grau relativamente alto de seguridade social aos cidadãos mexicanos. Tendo início com as reformas do Presidente Miguel de la Madrid em 1983 - reformas estas ditadas em grande parte por agências de crédito internacionais que estavam 'ajudando' o país a emergir da moratória do pagamento de sua dívida internacional - a política econômica teve um giro de 180 graus. Tomando o caminho do "livre-mercado" desbravado pelos "Chicago boys' e empregado pela ditadura chilena, o México inverteu todas as quatro diretrizes e entrou em um período de reforma que privatizou e desregulamentou a economia, abriu-a ao investimento estrangeiro e ao comércio, e despiu a força de trabalho - em especial o campesinato - de seus tradicionais mecanismos de apoio e proteção (tradução nossa). ${ }^{95}$

Desde o inicio, De la Madrid sinalizou qual ia ser a direção que ia dar aos rumos da economia mexicana: já no discurso de posse, fez criticas ao "populismo financeiro" do antecessor Portillo, que havia criado "uma economia ficcional" e advertiu que a austeridade se faria obrigatória naqueles primeiros meses de governo. Advertiu que estatização - porque era irracional - não iria ser a tônica de seu governo, de modo que, De la Madrid reverteu progressivamente as politicas do antecessor, ao reabrir o sistema bancário para o capital privado e ao cortar drasticamente gastos públicos. ${ }^{96}$ Com efeito, De la Madrid aumentou o papel dos tecnocratas e de uma elite política com formação intelectual no exterior, na maioria em finanças e administração. ${ }^{97} \mathrm{Na}$ cúpula de seu

\footnotetext{
94 KELLY, Thomas J. "Neoliberal Reforms and Rural Poverty". Latin American Perspectives 28(3): 84103, 2001, p.85.

95 BARKIN, 1997, p.20. Four components had guided Mexican economic policy: a high degree of state participation in the economy; a strategy of 'stable development' which attempted to keep prices, interest rates and the exchange rate under control; the protection of domestic industry with high tariff and nontariff barriers to international trade and investment; and an attempt to provide a relatively high degree of social security to mexican citizens.Beginning with the reforms of President Miguel da la Madrid in 1983 - reforms dictated in large part by the international lending agencies which were 'helping' the country emerge from its moratorium on international debt payments - economic policy took a 180-degree turn. Embarking on the 'free-market' path pioneered by the 'Chicago boys' employed by the Chilean dictatorship, Mexico reversed all four directions and entered into a period of reform that privatized and deregulated the economy, opened it to international investment and trade, and cut loose the workforce especially the peasantry - from its traditional protections and supports.

${ }^{96}$ HIGGINS, 2004, p.139.

${ }^{97}$ Cf. CENTENO, 1994.
} 
gabinete constavam nomes de economistas formados nas melhores universidades dos EUA (Harvard, MIT, Stanford, Yale e, sobretudo, Chicago), leitores de Hayek, Friedman e Von Mises,e que acreditavam na racionalidade da economia. Apelidados de técnicos, começaram a desmantelar o estado mexicano, ${ }^{98}$ em um movimento diametralmente oposto ao que sustentava o priismo. ${ }^{99}$

Fazendo um balanço crítico dos seis anos de mandato de Miguel de la Madrid, o resultado foi

o colapso próximo de $40 \%$ no valor dos salários, cortes de mais de $40 \%$ nos gastos sociais, um aumento de $15 \%$ do desemprego (de $9 \%$ para $24 \%$ da população economicamente ativa) e um agressivo programa de privatização. $\mathrm{O}$ resultado geral foi uma dramática redistribuição da riqueza para as mãos dos ricos - com uma queda de $41 \%$ para $29 \%$ na parcela do PIB constituída pelo trabalho (tradução nossa). ${ }^{100}$

O ano de 1982, desastroso para a economia do México em geral, transformou-se, ao iniciar o processo de neoliberalização do México, em ponto de inflexão na história do país.

No que se refere especificamente a Chiapas, De la Madrid lançou, em maio de 1983, o chamado Plan Chiapas, que visava unificar ações no nível federal e estadual para melhorar condições sociais das populações chiapanecas. É importante destacar que, no Estado, a exclusão política era patente, de tal maneira que as elites monopolizavam o poder político e econômico da região, recebendo apoio do governo federal em troco de assegurarem as vitórias eleitorias do PRI, em uma lógica de interesses mútuos que bloqueava as alternativas democráticas. ${ }^{101}$

Considerando o período estudado, pode-se fazer dois recortes históricos: a) governo de Absalón Castellanos Domínguez (1982-1988), que coincide com o governo De la Madrid e; b) governo de Patrocínio González Garrido (1988-1992), que coincide

\footnotetext{
${ }^{98}$ Idem, p.136.

99 De la Madrid, assim como Salinas e Zedillo, que seriam os presidentes seguintes, têm formação na área de Economia ou Administração e nunca haviam disputado um cargo eletivo antes.

${ }^{100}$ GONZÁLEZ, 2002, p.436. A collapse in the value of wages close to $40 \%$, cuts in social spending of over $40 \%$, a rise in unemployment of $15 \%$ (from $9 \%$ to $24 \%$ of the economically active population) and a rampant program of privatization. The overall outcome was a dramatic redistribution of wealth toward the rich - with labor's share of GDP falling from $41 \%$ to $29 \%$.

${ }^{101}$ Nas eleições de 1991 para o congresso, o PRI saiu com 100\% dos votos na cidade de Oxchuc, dos 11.073 eleitores.
} 
com o governo Salinas, administrações sob as quais aumentaram as estatísticas de repressão em Chiapas (segundo relatório da Humans Right Watch de 1991). Ambos os governadores militarizam a região, devido às turbulências políticas nos países vizinhos na América Central, tal como a Guatemala; de modo que as forças policiais passaram, assim, a estar sob o comando do exército.

Castellanos e Gonzálvez eram considerados membros da "linha-dura" do partido. O governo Castellanos perpetrou o assassinato de 102 camponeses; desparecimento de 327; aprisionamento de 590; sequestro e tortura de 427; expulsão de 407 famílias de suas casas. ${ }^{102}$ Decretou um código penal severo a "crimes contra segurança interna", para fatos que no resto do mundo democrático seriam vistos como manifestações políticas legítimas e pacíficas. Como pondera Oppenheimer,

O Artigo 225 do Código Penal de Chiapas estabelecia penas de até quatro anos de prisão para aqueles que ocupassem terras, prédios e praças públicas, 'ou obstruíssem artérias de comunicação', o que significava que maias sofriam o risco de longa estada na prisão meramente por levar seus protestos à rua (tradução nossa). ${ }^{103}$

Com o sucessor González Garrido as coisas se deterioraram. Primo do presidente Salinas, em um mês no poder, dois dos principais líderes políticos de oposição no Estado são assassinados, segundo Burbach. ${ }^{104}$ Conhecido também como “dinossauro", estimulou a formação do grupo paramilitar das Guardias Blancas. Sob seu governo, aumentou o número de protestos por parte de uniões de camponeses e o Estado tornou maior o número de presos em uma política que priorizava a construção de presídios e uso de violência. Com a reforma do código penal, em 1990, Garrido colocou 2290 indígenas na cadeia, segundo o Instituto Nacional Indigenista (INI).

\footnotetext{
${ }^{102}$ HAYDEN, 2002, p.10.

103 OPPENHEIMER, p.50. Article 225 of Chiapas' Criminal Code called for sentences of up to four years in prison for those seizing land, buildings, public squares, 'or obstructing communication arteries', which meant that Mayans risked long term in jail just for taking their protests to the street.

${ }^{104}$ BURBACH, Roger. Globalization and Postmodern Politics. London: Pluto Press, 2001.
} 
"Toda morte matada,

toda morte morrida,

se for vida doada,

não é morte, é vida"

(Dom Pedro Casaldáliga)

Considerando o objetivo de verificar o processo de formação do EZLN a partir da perspectiva dos militantes comunistas (e não dos padres progressistas ou até mesmo dos indígenas chiapanescos, ambos igualmente importantes para a formação da utopia zapatista) - em que se pese o foco central de avaliar, especialmente, o papel político e intelectual do Subcomandante Marcos nesse processo -, nos pareceu necessário resgatar brevemente a história dos grupos de esquerda que atuavam no México e, em particular, em Chiapas antes do levante zapatista.

Desde que rebeldes armados atacaram uma guarnição militar em Ciudad Madera, no Estado de Chihuahua, no dia 23 de setembro de 1965, que o governo central mexicano passou a estar consciente da existência de guerrilheiros que poderiam colocar em prática seu descontentamento com o regime por meios armados. ${ }^{105}$ Carlos Montemayor, estudioso dos grupos de guerrilha mexicanos, identifica esse ataque como sendo o ponto de partida para um status de "guerra não-oficial" que perduraria por décadas no país. E continua afirmando que "a partir de 1965, dezenas de grupos armados formaram-se inspirados no êxito da revolução cubana e na tradição agrarista mexicana, com suas filas engrossadas pela repressão ao movimento estudantil e cuja luta alcançou a sua fase mais intensa talvez entre 71 e $77^{\prime \prime}{ }^{106}$ Formaram-se, então, grupos fragmentados, com pouca interação entre si e que acreditavam em sua própria doutrina; não conseguiram enraizar-se na população de modo maciço, e, em alguma medida, fracassaram no intento de uma contraposição mais efetiva ao governo. ${ }^{107}$

\footnotetext{
${ }^{105}$ HIGGINS, 2004, p.127.

${ }^{106}$ MONTEMAYOR, 1997, pp.67-70. In: FIGUEIREDO, 2006, p.82.

${ }^{107}$ Para se ter uma ideia do número de grupos armados em atividade no México nas décadas de 60 e 70 , Higgins lista alguns dos principais: Movimiento Revolucionario del Pueblo, Partido de los Pobres, Asociación Cívica Nacional Revolucionária, Comando Urbano Lacandones "Patria Nueva", Frente Urbano Zapatista, Partido Revolucionario Obrero Clandestino Unión del Pueblo, Unión Campesina Independiente, Movimiento 23 de Septiembre, Liga Comunista Espartaco e Frente Revolucionario del Pueblo. Para aprofundamento, Cf. PEREYRA, 1994.
} 
Desde os anos 60, algumas correntes de esquerda já estavam trabalhando junto às dioceses na região meridional do México. Um grupo de importância que marcou presença em Chiapas, com inspirações maoístas, era a Linea Proletaria, conhecida também como LP. Formada no inicio dos anos 70, entre universitarios e professores na capital, a LP ajudou na mobilização de comunidades rurais e mesmo nas áreas urbanas pobres nos estados meridionais a demandar terra, moradia e assistência social. ${ }^{108} \mathrm{O}$ bispo da diocese de San Cristóbal de las Casas, Samuel Ruiz, indivíduo cujo ativismo em Chiapas ocupou por muitos anos lugar de destaque, entrou em contato com quadros dessas organizações em 1976, quando foi ao norte do país negociar libertação de padre acusado de trabalhar para eles. Os membros da LP trabalharam juntos com as comunidades de Chiapas naqueles anos e receberam apoio de padres maristas e dominicanos - muito embora a relação entre os grupos não tenha sido sempre de aliança, com atritos ocasionados sobretudo por questões religiosas e pela briga por espaço político. Segundo Womack, ${ }^{109}$ os jovens maoístas que trabalharam em Chiapas ajudam a formar, no final da década de 70, uniões de ejidos, que culminou, anos depois, na Unión de Uniones Ejidales y Grupos Campesinos Solidarios de Chiapas, instituição de grande importância política na realidade chiapaneca (negociavam com governo, demandavam programas de crédito, mobilizavam afiliados e organizaram atividades de greve na capital do Estado, Tuxla Gutierrez) e não visavam construir atividades clandestinas de guerrilha. ${ }^{110}$

Ao longo da década de 80, ocorreu uma série de rachas e disputas entre os grupos de oposição ao governo em Chiapas, sobre os quais não cabe discorrer aqui, dado o escopo de nosso trabalho. Vale apontar, contudo, que muitas vezes a tentativa de dividir o movimento camponês advinha da ingerência do próprio governo do PRI, com o governador Absallon Castellanos, que financiava organizações chapa-branca, oferecendo concessões aos filiados - paralelamente a intensa repressão aos líderes. ${ }^{111}$ São muitos os nomes das organizações - clandestinas ou não - que operaram em

\footnotetext{
${ }^{108}$ WOMACK, 1999, p.33.

${ }^{109}$ Idem, p.34.

${ }^{110}$ O Subcomandante Marcos, embora reconheça o trabalho de mobilização dos maoístas, tem uma visão crítica à sua postura enquanto militantes, quando afirma que "eles chegavam, despejavam sobre os indígenas um montão de ideologia e, depois que todos estavam bem proletarizados, diziam, bem, agora vocês façam tudo do jeito que estávamos dizendo, que nós vamos voltar à cidade para tomar um banho" (FUSER, 1995, p.115).

${ }^{111}$ FUSER, 1995, p.116.
} 
Chiapas mas vale fazer menção a duas organizações importantes naquele contexto, quais sejam, a Quiptic Ta Lecubtesel e a Slop. A Quiptic, formada em 1975, emergiu do congresso indígena de 74, organizado pelo bispo Ruiz. E a Slop, fundada em meados dos anos 80 pelo próprio bispo a fim de recuperar a influência que julgava ter perdido. ${ }^{112}$

Em meio a tudo isso, formou-se no início dos anos 80 o Exército Zapatista de Libertação Nacional. Para o entendimento da origem do EZLN a partir da perspectiva dos jovens urbanos de matriz marxista - categoria em que Rafael Guillén se encaixava é fundamental discorrer, ainda que brevemente, sobre as Forças de Libertação Nacional, as FLN. As FLN foram fundadas em 6 de agosto de 1969, por jovens egressos da Universidade Nuevo León (grupo de Monterrey, capital do estado, um dos principais centros industriais do México), agrupados em torno do Instituto Cultural MexicanoCubano Frei Servando Teresa de Mier-José Martí. ${ }^{113}$ Os líderes do grupo eram os irmãos Yañez, de família de tradição de esquerda (seu pai era filiado ao Partido Comunista Mexicano, apenas para mencionar), César e Fernando. Ambos faziam costumeiras viagens a Havana, em Cuba, ao final da década de 60 e Cesar Germán Yañez participou do Ejército Insurgente Mexicano, o EIM, formado em resposta ao massacre de Tlatelolco pelo jornalista Mario Menéndez, de Iucatán. ${ }^{114}$ No começo da década de 70, no ano de 1972, as FLN chegaram à Selva Lacandona, em razão de suas pré-condições revolucionárias: instalaram o Núcleo Guerrilheiro Emiliano Zapata, que não duraria muito tempo, entretanto. César Germán Yañez foi morto em 1974 por forças de segurança e seu irmão Fernando passou a usar o codinome Germán em sua homenagem.

As FLN tinham celulas em Nuevo León, Veracruz, Puebla, Tabasco, Estado do México e Chiapas. No estado de Chihuahua estava a Frente Villista de Libertacion Nacional, com Rodolfo e índios tarahumaras; na capital estava a Escola de Quadros, dirigida por Rosa, sendo que melhores recrutas iam para lá. ${ }^{115}$ Animados pelas vitórias

\footnotetext{
${ }^{112}$ Marcos minimiza o papel da igreja na conscientização dos povos de Chiapas e alega que o projeto do bispo era divergente ao projeto do EZLN, sendo o primeiro uma "opção pela vida" e o último um "projeto de morte"; mas depois, em entrevista, Marcos disse que, para os zapatistas "morte é vida, em uma lógica tão absurda de uma morte cotidiana que se fez normal” (VARGAS, 2007, p.299);

113 TELLO DÍAZ, 1996, pp.61-65 e pp.96-100; FIGUEIREDO, 2006, p.83.

${ }^{114}$ FIGUEIREDO, 2006, p.83.

${ }^{115}$ Ibidem, p.84.
} 
sandinistas na Nicarágua em 1979, as FLN voltaram a focar sua atuação na região meridional do país. Mas somente no começo da década de 80 decidiram por formar um exército propriamente dito, desenvolvendo atividades de treinamento clandestino de guerrilha em 1983. Germán era o comandante das FLN e liderou os treinamentos da guerrilha em formação.

Como vimos, muito do arcabouço político encontrado por Marcos em Chiapas já havia sido construído antes, desde os anos 70 pelos padres da Igreja Católica e pelos grupos maoístas que se organizavam no Estado. O que não havia de modo sistemático no início dos anos 80 era um trabalho que visasse mais a instrução militar dos campesinos, de modo que esse foi um dos papeis desempenhados por Marcos e pelos outros guerrilheiros nos primeiros anos na formação do Exército Zapatista de Libertação Nacional. Segundo Guillermoprieto, ${ }^{116}$ os guerrilheiros usurparam a rede de trabalho dos padres para promover suas brigadas de auto-defesa, mas acabaram ganhando legitimidade ao oferecer serviços de saúde à população indígena. Nas palavras do próprio Marcos, em entrevista, admite que o aspecto militar era preponderante nas motivações para a formação da corrente sulista das FLN. Ele afirma que

Quando chegamos aqui pela primeira vez, falamos sobre a questão da luta armada. E os povos indígenas disseram 'sim, nós temos que pegar em armas e nos defender'; então começamos a treinar para a autodefesa, e não para como atacar. Foi assim que o EZLN nasceu, como uma força de autodefesa. E foi assim que crescemos (tradução nossa). ${ }^{117}$

Ao estudarmos os eventos cronologicamente (balizados ano a ano) no interior da guerrilha, alguns pontos nos pareceram importantes para maiores aprofundamentos. Realizamos uma leitura atentando para como se desenvolveram as atividades do grupo

\footnotetext{
${ }^{116}$ GUILLERMOPRIETO, Alma. "The Unmasking”. The New Yorker, March 13, 1995. In: HAYDEN, 2002, p.37.

${ }^{117}$ BENJAMIN, 1995, pp.64-65. When we first came here we talked about the issue of armed struggle. And the indigenous people said, 'yes, we have to take up arms and defend ourselves'; so we began to train for self-defense, not for how to attack. That's how the EZLN was born, as a self-defense force. And that's how we grew.
} 
nos anos iniciais, que se resumiam às atividades militares, treinamentos e ajudas às comunidades; observamos, além disso, depoimentos que retratam da vida difícil na selva, sobretudo para um jovem urbano como Marcos.

Desde o início da década de 80, as FLN passaram a adotar a estratégia maoísta de "guerra popular prolongada", ou seja, visavam realizar ações urbanas e rurais, com mobilizações em massa da sociedade civil para desgastar o governo. ${ }^{118} \mathrm{E}$ o EZLN nasceu a partir de referências políticas e militares das guerrilhas latinas dos anos $60 \mathrm{e}$ 70, com o intuito de derrubar o regime instituído e tomar o poder pelo povo. Quanto às atividades de guerrilha em geral, Montemayor faz a seguinte ponderação:

Os politicos e intelectuais têm conseguido convencer muitos mexicanos de que o guerilheiro é produto de uma ideologia e não de uma realidade social repressiva e que, portanto, apenas apareceu no nosso século a partir de uma leitura oportuna ou atrasada (segundo o analista que o impugne ou elogie) de livros que o radicalizaram ou por manipulações de países estrangeiros". E segue “(...) o guerrilheiro tem sido tradicionalmente camponês, que faz parte ou responde a insurreições indígenas ou camponesas, e que não é proveninete de uma influência ideológica determinada, mas que canaliza, através de uma ideologia dominante no momento, a consciência profunda de insurreição, de liberdade, de dignidade, de que a sua comarca padece ou vive". 119

O dia 17 de novembro de 1983 marcou a data de fundação do EZLN, quando os primeiros seis guerrilheiros fundaram o primeiro campo zapatista, próximo ao lago Miramar, no coração da Selva Lacandona, lugar que passa a ser chamado de La Pesadilla (O Pesadelo, na tradução para o português). Os seis eram: Germán, Elisa e Rodolfo, vindos de fora, e os indígenas Javier, Jorge e Frank. Tinham contruído relação de confiança com líderes locais, como Paco, indígena da etnia tzotzil, quem gradativamente foi ajudando na tarefa de mobilizar e trazer novos membros para o grupo, que viriam principalmente da região de Sabanilla.

No mês de maio de 1984, Germán deixou Chiapas para comandar as FLN diretamente da Cidade do México e deixou a corrente sulista a cargo de Elisa. Ela passou a ser responsável pelo treinamento dos novos recrutas, entre eles Rafael Guillén, que chegaria alguns meses depois. Depoimentos de colegas de guerrilha, em Grange e

\footnotetext{
${ }^{118}$ OPPENHEIMER, 1996, pp.58-59.

${ }^{119}$ MONTEMAYOR, 1998, pp.72-74.
} 
Rico, ${ }^{120}$ mencionam que Elisa não apresentava a força política que Germán detinha perante os companheiros, de modo que ficaria aberto um vácuo de poder a ser preenchido - e não demoraria muito para que justamente Marcos ocupasse esse lugar. ${ }^{121}$

Quando Marcos chegou, já eram nove pessoas no grupo, sendo que, neste momento, dois deles iam e voltavam à cidade para buscar suprimentos e fazer correspondências. É importante registrar que Marcos teria chegado a Chiapas em maio de 1984, segundo historiadores como Tello Díaz e Grange e Rico; entretanto, o próprio Marcos, no entanto, contesta essa afirmação, apontando que os autores não apresentam nenhuma fonte que comprove a veracidade da declaração. Ele sustenta que veio em agosto de 1984, precisamente no dia 6. Marcos tocou e explorou o assunto no comunicado "Abrirle una rendija a la historia", de setembro de 1999, em que fala dos quinze anos de sua estada em Chiapas. É possível, contudo, que o registro do dia 6 seja apenas uma escolha simbólica: 6 de agosto é a data de fundação das FLN, no ano de 1969 - o que sugere, no fundo, a identificação entre a pessoa e a causa, aspectos que se confundem constantemente na figura do Subcomandante - e que, afinal, são as preocupações de nosso trabalho -, manifestação do senso de ocasião de Marcos.

Marcos chegou com mais dois companheiros para se juntar ao grupo em La Pesadilla. Há vários relatos em que descreve suas dificuldades no contato inicial com a floresta, contando os dramas de suas primeiras experiências, expondo seus medos e sua vontade de voltar atrás. Muitos desses relatos encontram-se em um diário que Marcos escreveu à época de sua chegada, conforme aponta Tello Díaz. ${ }^{122}$ Em julho de 1994, Marcos enviou algumas páginas de seu diário ao editor da revista Proceso e trechos apareceram publicados na edição de 8 de agosto. Ele deu o relato de sua percepção quanto aos primeiros momentos de seu ingresso à Selva Lacandona, naquele Estado, no documentário canadense "A Place Called Chiapas”, de 1998:

Imagine uma pessoa que vem de uma cultura urbana. Uma das maiores cidades do mundo, com uma educação universitária, acostumada à vida na cidade. É como aterrissar em outro planeta. A língua, os arredores são novos. Você é visto como um alienígena vindo do espaço. Tudo lhe diz: 'Vá embora. Isso é um erro. Você não

\footnotetext{
${ }^{120}$ GRANGE e RICO, 1998, p.83 e p.175.

${ }^{121}$ HENCK, 2007, p.68.

122 TELLO DÍAZ, 1995, p.292.
} 
pertence a este lugar.' E isso é dito em uma língua estrangeira. Mas eles fazem com que você saiba, o povo, a maneira como agem; o tempo, quando chove; a luz do sol; o solo, o modo como se transforma em lama; as doenças; os insetos; a saudade de casa. Estão lhe dizendo 'Você não pertence a este lugar'. Se isso não é um pesadelo, o que é? (tradução nossa). ${ }^{123}$

No início, companheiros achavam que Marcos não resistiria às dificuldades, por apresentar-se "aburguesado", mas acaba os surpreendendo. Sobreviveu ao isolamento e às interpéries do tempo. Em suas palavras, a montanha os desafiava constantemente: "a montanha estava nos rejeitando. A montanha nos deixou com fome, doentes, lançou sobre nós a chuva e o frio. A agressão dos animais, insetos, tudo isso nos dizendo 'vão, saiam daqui, este lugar não é para vocês" (tradução nossa). ${ }^{124}$

Quando Guillén chegou a Chiapas, levou consigo uma dúzia de livros, que, um a um, foram sendo deixados para trás em virtude do cansaço provocado pelas primeiras caminhadas na selva. ${ }^{125}$ É interessante observar esse episódio como metáfora do processo de abertura de Marcos aos modos de pensar e de viver das comunidades, à medida em que vai se libertando de suas convicções e se dispondo a interagir com o novo. Em seu relato:

Dos 12 livros que carreguei comigo para a selva, um era "Canto General", de Pablo Neruda; outro foi uma seleção de poemas de Miguel Hernández; também levei poemas de Léon Felipe; "História de Cronopios y Famas", de Cortázar; as Memórias de Francisco Villa; Don Quixote... Eu não planejei nem refleti muito sobre isso antes de levá-los. Eles me disseram 'ok, você vai embora agora, junte suas coisas', e eu peguei os livros que estavam à mão, aqueles que lia com mais frequência ou que mais consultava. Eu tinha muitos mais, mas eles foram deixados para trás. Aqueles que trouxe, simplesmente joguei na mochila (tradução nossa). ${ }^{126}$

\footnotetext{
${ }^{123}$ Imagine a person who comes from an urban culture. One of the worlds biggest cities, with a university education, accustomed to city life. Its like landing on another planet. The language, the surroundings are new. Youre seen as an alien from outer space. Everything tells you: "Leave. This is a mistake. You dont belong in this place." Andits said in a foreign tongue. But they let you know, the people, the way they act; the weather, the way it rains; the sunshine; the earth, the way it turns to mud; the diseases; the insects; homesickness. Yourebeing told. "You dont belong here." If thats not a nightmare, what is?
}

${ }^{124}$ LANDAU, 2002, p.148. The mountain was rejecting us. The mountain made us hungry, sick, it pushed rain and cold on us. The aggression of animals, insects, all of this was saying: "go, get out of here, you have no business here"

125 Cf. McCAUGHAN, 1999.

${ }^{126}$ HUERTA, 1994, p.21. Of the 12 books that I carried with me to the jungle, one was Pablo Neruda's Canto General; another was a selection of poems by Miguel Hernández; also poems by Léon Felipe; Cortázar'sHistória de Cronopios y Famas; the Memoirs of Francisco Villa; Don Quixote... I did not plan this or reflect on it too much before taking them. They said to me 'ok, you're going to leave now, get your 
E continua em entrevista publicada na revista Proceso, de 21 de fevereiro de 1994:

Eu costumava carregar livros pelas montanhas, e fui repreendido por isso: por que estava carregando-os por aí? Realmente, era suicídio. Quando você chega pela primeira vez, você quer levar sua biblioteca inteira, certo? Mas o peso da munição, comida e tudo o mais é dividido igualmente, e além disso você está carregando livros. Você acaba se livrando deles, porque ninguém vai lhe dizer: 'bem, já que você está carregando tantos livros, vou the dar menos munição'. Não, você carrega a mesma quantidade... e eu me livrei deles gradualmente em diferentes acampamentos. (tradução nossa). ${ }^{127}$

É durante essa fase que praticamente todo o escalão do EZLN adotou novos nome de guerra. ${ }^{128}$ A escolha de Guillén pelo nome Marcos se deu em homenagem a Adelaido Villafranco, militante que usava esse codinome, que ele conheceu pessoalmente e tinha sido morto numa revista em um posto de controle da fronteira do exército em Puebla, em maio de 1983. ${ }^{129}$ Segundo ele, "Marcos é o nome de um colega que morreu, e sempre usamos os nomes daqueles que morreram nesta idéia de que um não morre se a luta continuar."130

Em entrevistas a Avillés e Minà e a Le Bot, Marcos afirmou que quando da sua chegada a Chiapas, a concepção de guerrilha "foquista-guevarista" ainda era muito presente entre os membros do EZLN, ${ }^{131}$ de modo que se pensava na organização em

stuff together', and I grabbed those books which came to hand, the ones I read most often or consulted most. I had many more, but they were left behind. The ones I brought I just chucked into my rucksack.

${ }^{127}$ Ele afirma que estava carregando uns 10 quilos em livros e que "there is a logic among guerrillas that states: one kilo weighs two after an hour. After two hours, it weighs four and you just want to dump the whole fucking lot". No original: "I used to carry books around in the mountains, and was scolded for it: why was I carrying them around? It was really suicide. When you first come, you want to bring your whole library, right? But the load of ammunition, food and everything else is divided equally, and on top of that you're carrying books. You end up getting rid of them, because no one is about to say: 'well, since you're carrying so many books, I'll give you less ammunition'. No, you carry the same amount... and I got rid of them gradually in the different camps". (publicado em Proceso, 21, fevereiro de 1994).

${ }^{128}$ Cf. WOMACK, 1999, p.191.

${ }^{129}$ Grange e Rico dão outra versão, depois contestada por Tello Díaz, de que teria tirado o nome em homenagem a Alfredo Zárate, segundo em comando das FLN, que também usava o nome de Marcos e havia sido morto em Neplanta em 1974.

${ }^{130}$ Haveria uma tradição entre os guerrilheiros da FSLN da Nicarágua, por onde Marcos passou, de adotar os nomes de companheiros mortos em ação (ZIMMERMANN, 2000, p.113; In: HENCK, 2007). Por isso, nosso título "A Morte e a Vida de Marcos", em alusão à morte do companheiro e ao "nascimento" do Subcomandante.

${ }^{131}$ AVILLÉS e MINÀ, 1998, p.115; LE BOT, 1997, p.109. 
termos tradicionais. E, na avaliação de Henck, ${ }^{132}$ o papel de Marcos mostrou-se imprescindível para a ampliação do movimento:

Como poderia o EZLN ser qualquer outra coisa quando a organização era liderada por Yáñez (codinome Gemán), que tinha cerca de quarenta anos e era um veterano dos movimentos guerrilheiros dos anos 1960 e 1970? Contudo, desde o princípio Marcos manteve uma abordagem um tanto mais flexível do que as de seus predecessores mais dogmáticos; e essa flexibilidade, embasada no pragmatismo e no realismo, foi o que permitiu ao EZLN adaptar-se e crescer (tradução nossa). ${ }^{133}$

No estágio dos primeiros anos, o EZLN evitou expandir seus contatos com habitantes locais, seja porque havia a necessidade de se pensar prioritariamente em sua própria sobrevivência, seja porque o momento exigia que se voltassem mais para preparação interna em termos militares. O trabalho de fortalecimento do grupo visava, ainda, dar aos guerrilheiros alguma legitimidade perante os líderes indígenas, mostrando ter experiência prática e serviços a oferecer. Marcos afirmou, em entrevistas, que os indígenas do grupo teriam ensinado tudo a ele e chega a se queixar aos jornalistas pelo desinteresse que mostravam por esse período de isolamento em que viviam.

Embora Sílvia Fernández, conhecida como Gabriela, fosse responsável pelo contato com o mundo urbano à época, a falta de informação era uma questão para os guerrilheiros no meio da floresta; adquiriam informação sobre a política mexicana apenas de poucas fontes, noticiadas pelas rádios, como a Rádio Havana de Cuba, Voice of America dos EUA, Rádio Exterior da Espanha e Rádio França Internacional. ${ }^{134}$

Em novembro de 1984, os nove combatentes que faziam parte do grupo comemoraram o aniversário de um ano do EZLN no campo "Margaret Thatcher" (colocaram esse nome em razão de terem caçado um porco que teria alguma semelhança coma “dama-de-ferro" britânica). Nessa época, Marcos já se mostrava adaptado às cirscunstâncias da vida na selva e foi subindo rapidamente na hierarquia militar do EZLN. Passou de subtentente a tenente e depois a segundo capitão em poucos meses.

\footnotetext{
${ }^{132}$ HENCK, 2007, p.67.

${ }^{133}$ Ibidem, p.67. How could the EZLN be anything else when the organization was headed by Yáñez (alias Gemán), in his forties and a veteran of the guerrilla movements of the 1960s and 1970s? However, from the outset Marcos maintained a somewhat more flexible approach than had some of his more dogmatic predecessors; and this flexibility, borne of pragmatism and realism, would be what allowed EZLN to adapt and grow.

${ }^{134}$ Já na segunda metade da década, Marcos viveu no acampamento "Cama de Nubes", onde conseguiram uma TV, o que teria melhorado o acesso a informações.
} 
Em menos de um ano, já havia adquirido a patente de subcomandante. No fim de 1984, adquiriu a função de treinar novos recrutas que ingressariam na selva, como Ana María (por vezes também chamada de Yolanda) e Mário. É importante mencionar que é nesta época que conheceu o Velho Antonio - há quem diga que seria uma construção da literatura do Subcomandante Marcos, mas o próprio Subcomandante Daniel confirma sua existência. O Velho Antonio estaria fugindo e Marcos o conhece casualmente; as conversas e ensinamentos do Velho Antonio mudariam a visão de Marcos, por falar sempre da perspectiva dos maias. ${ }^{135}$

O ano de 1985 - período em que há uma grande repressão por parte do governo do Estado - foi marcado pelos primeiros contatos mais efetivos com as comunidades locais. Nesse momento, os guerrilheiros julgaram haver necessidade política de contato, a fim de organizar as comunidades, levar a consciência aos povos para colocar em prática sua luta, nos termos da vanguarda revolucionária. Construíram um relacionamento especial com a etnia chol da região de Sabanilla e Francisco Lopez, líder chol que pertencia a Unión de Uniones, deu apoio ao EZLN. Assim, a primeira comunidade indígena aliada foi Tierra y Libertad. Quanto a esse contexto, Marcos diz a Le Bot que se teve início um processo muito secreto na formação da guerrilha, em que as famílias começavam a mandar seus filhos para os campos de treinamento zapatistas.

Os indígenas aceitaram fazer parte da estrutura militar por um interesse imediato, qual seja, proteger-se da repressão do governo do Estado e do grupo paramilitar das Guardias Blancas, de modo que os interesses de curto-prazo do EZLN e das comunidades acabavam por convergir. A obra de Gloria Muñoz Ramirez (lançada vinte anos depois da fundação do EZLN e baseada em testemunhos de pessoas que ajudaram o movimento entre 1983 e 1994) ${ }^{136}$ traz uma série de depoimentos sobre o processo de formação da guerrilha nessa fase, seu relacionamento com Marcos, entre outros temas concernentes à história clandestina do EZLN. Na obra, o Comandante Abraham relembra que muitos dos indígenas já haviam participado de lutas pacíficas, protestos contra o governo de Chiapas, mas salienta que "insurgentes falaram em entrar para luta revolucionária e eles aceitaram de primeira". O companheiro Raúl faz um relato de como era feito esses primeiros contatos para recrutamento, destacando que os

\footnotetext{
${ }^{135}$ MIGNOLO, 2010 p.13-14.

${ }^{136}$ RAMÍREZ, Gloria M. The Fire and the Word: A History of the Zapatista Movement. California: City Lights Publishers, 2003.
} 
guerrilheiros só iam até as vilas quando todos já estavam envolvidos em alguma medida com a causa. Raúl, ainda, lembra de quando conheceu Marcos, no acampamento "Malefício", em 1985, dizendo que "ele era muito jovem e muito magro, de tanto caminhar e subir as montanhas". O companheiro Geraldo fala que a primeira tarefa nas primeiras vilas zapatistas dizia respeito as medidas de segurança e lembra que a noite era "amiga dos zapatistas", uma vez que podiam se mover à vontade, sem tanto medo de serem vistos (hábito que foi cultivado pelo Subcomandante Marcos - seus hábitos noturnos mantidos, inclusive, ao receber jornalistas em Chiapas no meio da madrugada, fazendo-os esperar por sua chegada por horas). Nessa esteira, o EZLN começou a prover serviços para as populações locais, como campanhas de saúde, e começaram a construir em conjunto clínicas médicas em cada região conforme foram se estabelecendo. $^{137}$

Marcos julga que a estratégia de aproximação das comunidades pela via indireta, ou seja, pela intermediação de seus respectivos líderes passou a se mostrar bastante efetiva e os maiores êxitos na aproximação acabam se dando com as comunidades mais prósperas. Nas palavras de Marcos:

Começamos primeiro a fazer contato com essas comunidades indígenas, com esses chefes indígenas, e se conseguiu uma espécie de acordo tácito de ajuda mútua, um pacto de convivência entre o grupo armado e as comunidades ou esses chefes de comunidades. (...) Uma espécie de intercâmbio: 'nos ensinem a brigar e nós os ajudaremos a obter abastecimento' - que era nossa dificuldade - 'e a transportar suas coisas'. (...) Se dá uma espécie de relação de intercâmbio político e cultural. O choque, para nós, é que tínhamos que falar a língua. Os indígenas desses grupo intermediário conversam com as suas famílias, também indígenas, tzeltales, tzotziles, choles, tojolabales, e essas famílias decidem enviar seus filhos mais jovens à montanha para se tornarem guerrilheiros. ${ }^{138}$

Na obra de Ramirez, o Major Moisés fala sobre o recrutamento e sobre adaptação da organizacao para se fazer crescer entre indios. Ele era o comissário politico, tinha que explicar sua luta às famílias indigenas em cada vila. Explicava que a luta era por saúde e educação, que o governo nao ligava para indígenas e que a luta deveria ser de longo-prazo; aproveitavam para falar sobre Villa, Zapata e Hidalgo e de

\footnotetext{
${ }^{137}$ A já referida Ana María/Yolanda é uma das que trabalham como enfermeiras nas campanhas de saúde promovidas pelo EZLN.

${ }^{138}$ In: FIGUEIREDO, p.96.
} 
suas vitórias e que o pouco que tinham era graças a esses movimentos, mas que precisavam de mais para uma vida digna. ${ }^{139}$ Ganhar confiança das vilas era um grande salto para os insurgentes. E as vilas ajudavam a manter o EZLN: se antes a comida vinha da cidade, agora com os avanços politicos, a comunidade ajudava no sustento dos insurgentes ao mesmo tempo que incorporavam gradativamente os moradores da comunidade na estrutura. ${ }^{140}$

Um outro aspecto a se destacar nesse movimento de contato diz respeito à relação estabelecida com os párocos de Chiapas. Como aponta Figueiredo, ${ }^{141}$ as relações do EZLN com os catequistas passaram a ser mais respeitosas do que as que haviam entre os últimos e os maoístas - os quais, por rejeitarem as visões religiosas dos párocos, tendiam a ser mais radicais e acabavam por se distanciar das próprias comunidades - e começaram a trabalhar em conjunto. Cabe mencionar, também, que 1985 foi o ano da chegada de Salvador Morales, conhecido como Daniel, assistente na UAM, conhecido de Marcos. Daniel ficou apenas alguns meses na selva e voltou a militar nas FLN a partir da capital do país.

Foi a partir do ano de 1986 que Marcos desempenhou sua liderança de modo mais vigoroso, diminuindo progressivamente o jargão esquerdista que trazia consigo. No início daquele ano, Marcos e Lázaro Hernández, conhecido como Jesús, tomaram a iniciativa de organizar um encontro a fim de articular os camponeses com os trabalhadores urbanos do norte do país, que ficaria conhecido como "Primeiro Encontro Trabalhadores e Camponeses". Segundo Marcos, à época, o moral do grupo estava extremamente elevado, "achavam-se invencíveis" ${ }^{142}$ e aceleraram os recrutamentos. ${ }^{143}$

O Subcomandante atestou a incompatibilidade de linguagens entre guerrilheiros e indígenas e abandonou deliberadamente parte do léxico tradicional marxista, com uma preocupação mais ampla que visasse compreender os pontos de referência culturais dos povos de Chiapas - muito embora a inflexão mais drástica com relação às posturas tradicionais tenha ocorrido somente no início dos anos 90. Contudo, ao perceberem o

\footnotetext{
${ }^{139}$ RAMÍREZ, 2003, pp.74-75.

${ }^{140}$ Idem, p.75.

${ }^{141}$ FIGUEIREDO, p.92.

${ }^{142}$ HENCK, 2007, p.90.

143 Comandante Tacho lembra que ganharam a confiança das mulheres e destaca a importância do matriarcado nas comunidades locais.
} 
problema da linguagem, "não abandonam sua retórica marxista prontamente, sua conversão de falantes para ouvintes foi um processo lento". ${ }^{144}$

Marcos reconhece que "eles têm um substrato diferente, uma complexa préhistória de insurreições, então modificamos nossa abordagem de forma interativa" ${ }^{145}$ e "Marcos precisou parar de simplesmente reproduzir um dogma [marxista] estrangeiro em um idioma estrangeiro [castelhano] e começar a aprender as línguas indígenas, bem como seus pontos de referência culturais". ${ }^{146}$ O Subcomandante se propôs a aprender com os indígenas e progressivamente adquiriu grande legitimidade ao viver no dia-a-dia como eles viviam. Quanto a esse ponto, Grange e Rico trazem depoimentos de companheiros de guerrilha:

Dois outros Zapatistas indígenas, Subtenente Avelino e Tenente Nicodermo, explicam: 'Marcos não é pobre, mas ele vê e percebe os problemas dos indígenas. Ele tem a consciência limpa, andando durante dias na chuva, comendo como comemos, e se não há comida, ele também não come. Ele sofre como nós sofremos'. O relato é repetido por uma apoiadora zapatista em La Realidad, que comenta: 'o que os pobres comem, ele come. Quando ele está aqui, ele vai comer uma comida melhor? O que nós comemos, ele come. Se comermos legumes, ele também come. Não acreditamos que ele seja da cidade' (tradução nossa). ${ }^{147}$

Neste momento, a direção nacional das FLN era composta por Germán, Rodrigo, Elisa, Gabriela, Lúcia e Marcos, e o último, atuando diretamente em Chiapas, adquiriu cada vez mais protagonismo. Germán era considerado duro, de temperamento fechado representaria a ortodoxia, a "velha esquerda". Marcos, por sua vez, tinha outro temperamento, apresentava-se como alguém mais acessível, fazendo piadas o tempo todo, segundo relatos de companheiros. Segundo o raciocínio de Henck:

\footnotetext{
${ }^{144}$ HENCK, 2007, p.95.

${ }^{145}$ MONTALBÁN, 2002, p.139.

${ }^{146}$ HENCK, 2007, pp.94-95.

${ }^{147}$ GRANGE e RICO, 1998, p.175. Two other indigenous Zapatistas, Subtenente Avelino e Tenente Nicodermo, agree, explaining: 'Marcos is not poor, but he sees and realizes the problems of the indigenous. He has a clear conscience, walking for days in the rain, eating the same as us, and if there is no food, he doesn't eat either. He suffers like us'. This is echoed by a female Zapatista supporter in La Realidad, who comments: 'whatever the poor eat, he eats. When he is here, is he going to eat better food? What we eat, he eats. If we eat vegetables, he does too. We don't believe he is from the city'.
} 
a recém descoberta independência em relação a Elisa e a outros dirigentes do FLN da qual Marcos agora usufruía com seu novo comando e com a liderança de seu próprio acampamento era muito significativa para que Rafael se transformasse no Marcos que conhecemos hoje. Agora ele podia gozar de alguma autonomia e dar plena expressão a sua personalidade. Marcos era muito diferente dos demais (tradução nossa). ${ }^{148}$

Em 1987, ocorreu um evento que teve importância para Marcos do ponto de vista individual, mas que acaba tendo efeitos que transbordam para a coletividade das comunidades zapatistas. O Subcomandante casou-se com Ana María, em cerimônia próxima ao ejido de Pichucalco, a alguns quilômetros de Sabanilla, cidade de onde ela vinha. Ela tinha experiências no trabalho como auxiliar de enfermagem no hospital Las Hermanas de San Vicente em San Andrés Larráinzar, uma das cidades mais pobres do Estado. Outros casamentos ocorreram no mesmo dia, denominados "casamentos revolucionários", que não seriam nem católicos, nem indígenas, sendo os noivos declarados "marido e mulher em nome da revolução", depois de passarem por debaixo de dois fuzis entrecruzados.

Os padres não viram o evento de modo positivo. Além de subverter uma prerrogativa da Igreja, eles estavam estimulando uma revolução sexual nas comunidades, disseminando métodos contraceptivos e, de algum modo, reestruturando relações de gênero instituídas. Ainda, os casamentos revolucionários contrariavam, além dos padres, algumas famílias uma vez que as moças acabavam se casando sem pedir permisão aos pais. Os “casamentos revolucionários” impactaram nas relações entre o Subcomandante Marcos e o Bispo Samuel Ruiz nos anos seguintes.

"The fact that the revolution is impossible does not make it morally less necessary, nor the reasons for revolt less urgent, even without an alternative. The PRI are still scum, and the country they propose is still a mixture of economic misery for many, social misery for the majority and moral misery for all."

(Paco IgnacioTaibo II, 1990)

\footnotetext{
${ }^{148}$ HENCK, 2007, p.97.The newfound independence from Elisa and other more senior FLN cadres that Marcos now enjoyed through his new command and through being in charge of his own camp was highly significant for his development from Rafael to the Marcos we know today. Now he could enjoy some autonomy and give full expression to his personality. Marcos was of a very different from the others.
} 
No cenário mais amplo, a insatisfação das camadas populares com as reformas se fez sentir nas eleições de 1988. Carlos Salinas de Gortari, o candidato "natural" pelo PRI para ocupar a presidência mexicana, havia sido, assim como De la Madrid, o Secretário de Finanças e Planejamento do governo, e tinha se formado em Economia por Harvard nos Estados Unidos. Porém, Cuauhtémoc Cárdenas (filho do ex-presidente Lázaro Cárdenas) e governador do Estado de Michoacán se apresentou como candidato alternativo depois de romper com o PRI e formar uma coalizão oposicionista, a Frente Democrática Nacional (composta por muitos priístas, de correntes mais nacionalistas, descontentes com intervenções do FMI durante os anos De la Madrid), para concorrer às eleições.

Apesar do grande apoio popular à candidatura de Cárdenas, Salinas apareceu como vencedor do pleito ainda que com a menor votação obtida por um candidato priista em toda a sua história, 50,4 por cento. ${ }^{149}$ Boa parte da população e a oposição em geral não concordou com o resultado, considerando-o fraudulento. No meio da apuração, enquanto Cárdenas estava na frente de Salinas (a pesquisa de boca-de-urna já apontava a derrota do governo), ocorreu uma pane nos computadores que divulgavam os resultados parciais; quando o sistema voltou, Salinas já apareceu na frente na apuração. Foram alguns meses de manifestações intensas contra o pleito. Salinas, ainda assim, foi empossado. Contudo, em algumas prefeituras, pela primeira vez na história moderna mexicana, venceriam candidatos que não do PRI, especialmente os do Partido da Ação Nacional. ${ }^{150}$

Carlos Salinas de Gortari, o tecnocrata promissor aos olhos de De la Madrid, que não havia sido eleito a nada até então e considerado fascinante pelo mundo dos negócios no exterior, foi "o presidente que prometeu levar o México aos umbrais do Primeiro Mundo desenvolvido, democrático e civilizado, chegou ao poder através da fraude mais escandalosa da história política do Ocidente". ${ }^{151}$

Ao longo de seu mandato, Salinas viajou oito vezes para os EUA (George H. Bush foi uma vez ao México no mesmo período), privatizou mais que Thatcher,

\footnotetext{
${ }^{149}$ Contra 30,9\% de Cárdenas e 16,7\% de Manuel Clouthier, do PAN.

150 O Partido da Ação Nacional, formado em 1939, é uma agremiação política de base pró-empresarial e favorável às reformas pró-mercado, sendo colocado no campo da direita (no espectro político) por diversos analistas.

${ }^{151}$ FUSER, 1995, p.25.
} 
reestabeleceu relações com o Vaticano e conseguiu apoio da hierarquia conservadora para desestabilizar o clero progressista e afastar o bispo Samuel Ruiz da cena nacional. ${ }^{152}$ Colocou em prática a chamada "salinastroika": os gastos com educação caem $21 \%$, os com saúde vão de $4,7 \%$ do PIB para $2,7 \%$. O PIB cresceu $0,4 \%$ nos seis anos de seu mandato e a concentração de renda explodiu: os $10 \%$ mais ricos do país detinham $60 \%$ do PIB (cinco anos antes tinham 38\%). Suas políticas de privatização e desregulação criaram uma geração de bilionários mexicanos (Carlos Slim é o caso mais famoso): 24 nomes apareceram na lista da revista Forbes em 1993.

Salinas, embora seja certamente o mais neoliberal dos presidentes do México, foi também o primeiro a incorporar um aspecto social dentro do neoliberalismo mexicano, ao lançar o Programa Nacional de Solidariedade, conhecido como PRONASOL, em 1988. Apesar da faceta social, a ênfase era na responsabilidade pessoal de quem recebia os benefícios e na identificação com o Estado priísta. ${ }^{153} \mathrm{O}$ PRONASOL se mostraria uma cartada magistral de sua gestão, ${ }^{154}$ uma vez que ele inverteu a relação com o PRI: focado centralmente no programa, manteve os correligionários do partido afastados da cena política nacional durante os seis anos de mandato e acabou por dar vazão a uma estrutura paralela de relações que girava em torno do eixo do PRONASOL (cogitou-se, inclusive em lançar o Partido da Solidariedade, dissovendo o PRI). ${ }^{155}$ De qualquer maneira, o programa era controlado pelos "caciques" do PRI em nível local, sem nenhum contato com movimentos que não estivessem vinculados ao partido - foi justamente o que ocorreu no Estado de Chiapas, maior beneficiado pelo programa. Fuser classifica o PRONASOL como uma "gigantesca operaço de troca de verbas e serviços públicos por votos e apoio político". ${ }^{156}$ O Subcomandante Marcos manifestou sua opinião sobre o programa em entrevista:

Pronasol tem a mentalidade de um filho da puta que vê os povos indígenas como crianças, como crianças mal-educadas. Em vez de dar as palmadas que seus filhos

\footnotetext{
${ }^{152}$ Ibidem, p.35-36.

${ }^{153}$ HIGGINS, 2004, p.140.

${ }^{154}$ FUSER, 1995, p.42.

${ }^{155}$ Ibidem, p.42.

${ }^{156}$ FUSER, 1995, p.47.
} 
merecem, o pai - que é tão compreensivo e generoso - lhes dará doces depois que prometerem que não vão se comportar mal novamente (tradução nossa). ${ }^{157}$

O México, que havia entrado no GATT (Acordo Geral sobre Tarifas e Comércio) em 1986, ainda no governo de Miguel de la Madrid, começou a negociar o North American Free-Trade Agreement, o NAFTA. O projeto começou a ser gestado ainda em 1987, quando Salinas, então ministro das finanças e George H. Bush, então vice-presidente dos EUA cogitam a ideia em encontros nos EUA e o primeiro encontro já como presidentes se dá em Houston, no ano de 1989 (após a consecução de acordos bilaterais entre EUA e Canadá). Como afirma Higgins, ${ }^{158}$ o processo foi conduzido apenas no nivel das elites mexicanas dirigentes e o debate sobre as implicações e benefícios da entrada no bloco nunca foi seriamente desenvolvido, da tal maneira que a sociedade mexicana nunca foi consultada. Do lado mexicano, as negociações foram conduzidas por José Córdoba Montoya, homem forte de Salinas; e do lado estadunidense, a negociadora oficial era Carla Hills, quem afirmou, em 1990, que o México deveria reformar sua constituição, em especial no que tangia ao artigo 27, para que os estrangeiros tivesse clareza sobre as regras para a segurança de seus investimentos. ${ }^{159}$ Com efeito, as políticas regionais ficaram subordinadas aos interesses de Salinas em termos macroeconômicos, ${ }^{160}$ o que inevitavelmente impactou na sociedade chiapaneca, em especial para os campesinos e indígenas.

Com a fraude das eleições de 6 de julho de 1988, os camponeses ficaram mais desiludidos com a via eleitoral e a adesão ao EZLN tornou-se maior neste ano. E, de modo geral, com a implementação das politícas de orientação neoliberal, entre 1988 e 1992, o EZLN agregou milhares de combatentes; ao fim de 1992 já estavam próximos dos 5 mil e Grange e Rico afirmam que esse ano foi o ápice do movimento em termos numéricos. Segundo Marcos, em entrevista para Le Bot, o período

\footnotetext{
${ }^{157}$ McCAUGHAN, 1995, p.37. Pronasol has the mentality of a son-of-a-bitch that sees the indigenous people like children, as ill-bred children. Instead of giving his kids a spanking like they deserve, the father - who is so understanding and generous - is going to give them candy after getting them to promise not to misbehave again.

${ }^{158}$ HIGGINS, pp.42-43.

${ }^{159}$ Idem, p.122.

${ }^{160}$ Idem, p.148.
} 
Foi um boom do zapatismo, uma expansão fenomenal, fora de toda proporção, que prontamente começou a preencher esses organograma que havia sido um sonho ou pesadelo em 83-84: companhias, batalhões, divisões (...). Então começamos a organizar tal como pensávamos que tinha que ser um exército popular. Ou seja, um exército para lutar e produzir, que não só se preparava para o combate, mas que fazia trabalhos de serviço nas comunidades. Nosso exército trabalhava milpas [terra onde se cultiva milho e, às vezes outras plantas] coletivas, fazia o que agora fazemos nos Aguascalientes: clínicas, centros de reunião, campos esportivos onde se juntava a unidade militar e se colocava a trabalhar e fazia um parque infantil, coisas para o serviço da comunidade. ${ }^{161}$

E no que se referia ao primeiro ano de governo de Salinas, Marcos destaca o crescimento do movimento:

nós zapatistas passamos de dezenas para milhares em pouco tempo; estou falando de um único ano, 1988-1989. Passamos de oitenta combatentes para 1.300 em menos de um ano (...) dentre os vários ingredientes que explicam o crescimento massivo do EZLN... um foi a fraude contra Cardenas, que significou o cancelamento da possibilidade de transição pacífica para um determinado setor de indígenas, os mais politizados, acima de todos aqueles da Unión de Uniones (tradução nossa). ${ }^{162}$

Foi nesse contexto que Salvador Morales, conhecido como Daniel, retornou a Chiapas da capital do país e voltou com a patente de subcomandante. Tal fato provocou alguns questionamentos por parte de Marcos, que não o via com credenciais para assumir o posto, em razão de não ter vivido tudo o que ele próprio havia passado na selva e mesmo assim, agora, teria o mesmo nível na hierarquia militar. ${ }^{163}$ De outro lado, Daniel parecia cultivar algum ressentimento com relação a Marcos, pelo modo como ele se colocava frente ao grupo. Marcos cuidava livremente das finanças do EZLN, tarefa a qual passava agora para os cuidados de Daniel. Sem contar que Elisa tinha ido embora da Selva Lacandona por estar grávida e Marcos passado a estar formalmente em comando pela Frente de Combate Sur-Oriental, ${ }^{164}$ uma vez que já comandava de fato. Com todos esses ingredientes somados, a rivalidade entre os dois estava posta.

\footnotetext{
${ }^{161}$ In: FIGUEIREDO, p.101.

${ }^{162}$ HENCK, 2007, p.114. We zapatistas passed from tens to thousands in a short time; I am speaking of a single year, 1988-89. We passed from being eighty combatants to 1.300 in less than a year (...) of the various ingredients that explain the massive growth of the EZLN... one was the fraud against Cardenas, which signified the cancellation of a possibility of a peaceful transition for a certain sector of the indigenous, the most politicized, above all those from the Unión de Uniones.

${ }^{163}$ HENCK, 2007, p.115.

${ }^{164}$ TELLO DÍAZ, 1995, pp.113-115.
} 
Um outro aspecto a ser destacado foi o desgaste, em 1988, entre o EZLN e a Igreja Católica de Chiapas. Ruiz afirmava que o EZLN tinha usufruído de toda a rede contruída pelos padres, comparando-os a uma planta parasita; em outras palavras, o bispo disse ainda que o EZLN veio "montar cavalo domado". E, conforme dissemos, os “casamentos revolucionários" passaram a desagradar cada vez mais a Ruiz, algo que era visto por ele como sacrilégio. Então, Ruiz buscou canalizar sua luta política pela revitalização da Slop e conseguiu, no fim das contas, demarcar um espaço de atuação que não batesse de frente com os zapatistas. Conforme os meses foram passando, a relação do bispo com o Subcomandante Marcos melhorou, apesar de algumas brigas e disputas cotidianas.

A grande aproximação do EZLN com as comunidades ocorreu em 1989: as populações locais iam até os acampamentos zapatistas, faziam festas e celebrações e interagiam cada vez mais. A organização havia crescido bastante e precisava de avanços nas comunicações internas - aí desenvolveram o sistema de comunicação via rádio; além disso, organizaram encontros regionais para se reconhecerem, dar senso de coesão e tomarem conhecimento da dimensão que estavam tomando.

De um lado, nesses anos, ocorreram vários eventos que significariam o desmoronamento da alternativa comunista, que arrefecia os ânimos das esquerdas pelo mundo, pela desmoralização de seus projetos históricos, em um contexto mais amplo do suposto triunfo final do capitalismo. ${ }^{165}$ De outro lado, o sucesso no não-esmorecimento da luta zapatista, para Henck, reside justamente nas habilidades pessoais de Marcos, sobretudo no que se refere a não resgatar doutrinas fossilizadas, nem renunciar a toda a herança e crenças que carregavam. ${ }^{166}$ Ele foi recriando práticas de participação política, mas do que uma mera reprodução das tradições.

Quanto mais as comunidades e o EZLN interagiam, mais tinham que se adaptar uns aos outros. Marcos assegura que este foi o momento-chave para a passagem da concepção de vanguarda revolucionária para o movimento de resistência indígena que transformaria o EZLN, ainda que o processo não fosse completamente livre de obstáculos para ambas as partes. O início da década de 90 instituiu novos padrões de deliberação dentro do movimento, agora não mais verticais, impositivas, vindas "de

\footnotetext{
${ }^{165}$ O clima de "fim da história" já havia sido anunciado pela primeira-ministra do Reino Unido, Margaret Thatcher, com o famoso slogan "There is no Alternative!".

${ }^{166}$ HENCK, 2007, p.130.
} 
cima a baixo", mas sim horizontais e coletivamente construídas. ${ }^{167} \mathrm{O}$ poder político do movimento foi descentralizado, garantindo autonomia às comunidades dentro da organização. Essa rede de comunidades zapatistas que foi se fortalecendo por meio de comandos interregionais, o que fortificou o EZLN do ponto de vista político e culminou na criação do Comitê Clandestino Revolucionário Indígena (CCRI), em 1993. Do ponto de vista militar, cada um dos três subcomandantes (Marcos, Daniel e Pedro) dirigiria um regimento de aproximadamente 1.500 combatentes, a saber, El Machete, La Hacha e El Martillo. Nas palavras do próprio Subcomandante Marcos na entrevista a Le Bot:

A virtude dessa organização militar está em reconhecer que não tinha resposta e que tinha que aprender. Essa é a primeira derrota do EZLN e que o marcará daí em diante. (...) E aí começa a se dar o processo de transformação do EZLN, de um exército de vanguarda revolucionária a um exército das comunidades indígenas, um exército que é parte de um movimento indígena de resistência, dentro de outras formas de luta. Nós não o percebíamos assim; para nós a luta armada era a coluna vertebral, o escalão mais alto etc. (...) Mas logo o EZLN, quando se imbrica com as comunidades, passa a ser um elemento a mais dentro de toda essa resistência, se contamina e é subordinado às comunidades. (...) Eu penso que o que permitiu ao EZLN sobreviver e crescer foi aceitar essa derrota. Se o EZLN não a tivesse aceitado, teria se ilhado, teria ficado pequeno, teria desaparecido, nunca teria nascido o EZLN que aparece no $1^{\circ}$ de janeiro de $1994 .^{168}$

Dois eventos do ano de 1992 contribuiram para uma vigorosa expansão do EZLN. O primeiro evento foi a celebração internacional do "ano do indígena", que aumentou o orgulho das populações de raízes indígenas. ${ }^{169}$ Logo em janeiro, o governo revisou o artigo 4 da Constituição Mexicana para reconhecer direitos dos indígenas; ainda, o governo mexicano ratificou as convenções 107 e 169 da OIT, sobre direitos coletivos e de minorias (foi o segundo país a ratificar, depois apenas da Noruega). Rigoberta Menchú, ativista guatemalteca ganhou o prêmio Nobel da Paz daquele ano, o que também elevou a auto-estima das populações indígenas.

O segundo evento diz respeito à aprovação do congresso, como parte de uma exigência explícita dos Estados Unidos ${ }^{170}$ de uma mudança constitucional que afetava diretamente os camponeses e indígenas, e que poderia implicar em ainda mais prejuízo a esses grupos: a revogação do artigo 27 da Constituição Mexicana de 1917. Os ejidos,

\footnotetext{
${ }^{167}$ HENCK, 2007, p.134.

${ }^{168}$ In: FIGUEIREDO, pp.104-105.

${ }^{169}$ Em 1993, a ONU publicaria a Declaração dos Direitos Indígenas.

${ }^{170}$ BUENROSTRO y ARELLANO, 2002, p.50.
} 
garantidos pela carta magna pelo referido artigo, deixariam de ser propriedades comunais, podendo então ser confiscados e comercializados pelos bancos, e o tamanho das propriedades rurais deixou de ser limitado, ${ }^{171}$ isto é, os latifúndios, formato de propriedade agrícola ideal para o agronegócio e para a competição internacional em grande escala seriam então legalizados. Segundo Mattiace (p.144), a terra para esses grupos tinha uma dimensão não só material; além disso, ela tinha laços e significados espirituais e simbólicos para a vida das comunidades. Com efeito, Marcos reclamou a perda da própria história com a perda da terra e ele afirmou que a reforma do artigo 27 radicalizava as posições dos companheiros do EZLN, de maneira que filiações massivas foram feitas ao movimento.

Em março de 1992, Marcos foi à Cidade do México com Ana María para se tratar de uma gastrite que o fazia vomitar em toda refeição e aproveitou e visitou a família em Tampico. No mesmo mês, aproximadamente 400 chiapanecos marcharam de Palenque até a Cidade do México, num trajeto de $1.106 \mathrm{~km}$. A marcha ficou conhecida como Xi'Nich (marcha das formigas em chol) e recebeu grande atenção da midia nacional. Liderada pelo padre jesuíta Jerónimo Hernandez, os chiapanecos demandaram a libertação de presos por ordem do governador; de modo genérico, o governo central prometeu melhorar a situação dos indígenas.

Neste momento, o Subcomandante Marcos havia se tornado um líder indispensável e não tinha mais como dar meia-volta. ${ }^{172}$ Ele, que se mostraria consciente de seu papel como líder romântico irresistível após o levante, ${ }^{173}$ já conseguia agregar cada vez mais militantes chiapanescos, o que fornecia enraizamento popular ao EZLN pela sua habilidade de radicalizar o que descontentava por si só os camponeses, a saber, a questão do artigo 27. Como vimos, ao longo de toda a década de 80, o EZLN desempenhou um profundo e paciente trabalho entre as comunidades, mas somente com a guinada completa em relação ao discurso que as FLN mantinham desde o final da década de 60 que passou a obter maiores êxitos na tarefa de mobilização, uma vez que o esquema tradicional não se encaixava dentro das expectativas e visões de mundo dos

\footnotetext{
${ }^{171}$ Ibidem, p.50.

${ }^{172}$ HENCK, 2007, p.157.

${ }^{173}$ KLEIN, 2001, p.117.
} 
índios. ${ }^{174} \mathrm{O}$ outro fator essencial para o sucesso se deu justamente com a contraposição ao projeto neoliberal, pela denúncia de que seus efeitos locais seriam nefastos.

Por ocasião das vindouras comemorações de 500 anos da chegada de Colombo, Marcos decidiu colocar em consulta às bases se era hora de entrar em guerra, alegando, afinal, ser a razão primeira da existência do EZLN. ${ }^{175}$ A opção pela ida à guerra em 1992 venceu, mas cálculos políticos os fizeram recuar. Detratores atribuem a Marcos manipulação das vontades dos indígenas, como é o caso dos depoimentos que o Subcomandante Daniel fez posteriormente (falou de manobras de Marcos, alegou ter forjado as atas das assembleias, entre outras acusações). Houve também, no processo, tensões entre as visões de Marcos e do Comandante Rodrigo que fez críticas ao modo como Marcos operaria, classificando-o de centralizador. Marcos, por sua vez, alegou que tinha medo de procastinar a guerra e acabou tolhendo o entusiasmo dos indígenas e arrefecendo sua mobilização no EZLN. De todo modo, no dia 12 de outubro de 1992, data que marca a chegada de Colombo, houve demonstrações de resistência em San Cristóbal de las Casas, onde 10.000 foram presentes. O ato mais simbólico foi a derrubada da estátua do conquistador Diego de Mazarriegos (Marcos participou da manifestação como cinegrafista amador).

No mês de janeiro de 1993, entre os dias 23 e 25, ocorreu um encontro da cúpula das FLN, na vila de Prado em Ocosingo, a fim de discutir os rumos da organização. Elaboraram um documento em que, segundo Grande e Rico, a ortodoxia dos estatutos de 1980 ainda permaneceu presente, em que se pesou o fato de ter sido escrito pelo veterano Rodrigo. No encontro, os membros debateram e ratificaram as chamadas leyes revolucionarias, esboçadas poucos meses antes. E, ainda, o encontro criou o Comitê Clandestino Revolucionário Indígena (CCRI), instância máxima de deliberação da frente sul, o EZLN. Chegou-se também a cogitar a formação de um partido, o que evidencia o modo mais ortodoxo do qual as lideranças tradicionais pensavam.

Neste ano, voltou-se a debater sobre a eventualidade de levar a cabo uma guerra contra o governo central. O Subcomandante Marcos deu uma série de justificativas em favor da ida à guerra, novamente argumentando que era raison d'être do EZLN, e trazia para a discussão a impaciência de alguns indígenas, que haviam vendido pertences para comprar armas; conforme apontavam, os militantes estavam cansados de ouvir falar em

\footnotetext{
${ }^{174}$ VARGAS, 2007, p.108.

${ }^{175}$ O modelo de consulta passa, a partir dessa época, a ser modelo regular na organização zapatista.
} 
insurreição que nunca chegava. Segundo Marcos, alguns líderes comunitários haviam dado ultimato a ele: se em um ano não se fosse decidido ir à guerra e construído os arranjos logísticos para tanto, iriam mesmo sem Marcos e sem o alto-escalão zapatista. Ao reproduzir essa demanda, Marcos apresentava (sobretudo ao Rodrigo) a visão de que a guerra era inevitável.Marcos acreditava que Las Cañadas estava suficientemente madura para insurreição, devendo servir como faísca revolucionária para todo o México.

Desta maneira, a votação ocorreu com a vitória da posição favorável à guerra e o ano de 1993 foi, no conjunto, todo dedicado a pensar como a colocar em prática do ponto de vista logístico. Nessa esteira, ocorreram mudanças na hierarquia do EZLN: Marcos foi nomeado chefe-militar e Germán ficou como chefe-geral; Rodrigo foi colocado de canto e acabou decidindo sair da organização junto com Gabriela. Num primeiro momento, o bispo Ruiz fez campanha contra a ida à guerra, que ele denominava "suicida", mas disputas eclesiásticas acabaram desviando atenção do clero e Ruiz não conseguiu despender esforços reais para prevenir a guerra. ${ }^{176}$

Em maio de 1993, os zapatistas fizeram a compra de balaclavas, que virariam símbolo do movimento, e de parte dos uniformes e de outras roupas em um mercado de San Cristóbal de las Casas e Ocosingo. No mesmo mês, o acampamento zapatista de Las Cabazas foi descoberto por forças do governo. ${ }^{177} \mathrm{O}$ presidente Salinas, no entanto, preferiu "fazer vistas grossas" ao evento, priorizando a implementação do NAFTA. O ministro do interior, Patrocínio Gonzalez, que havia sido governador do Estado de Chiapas, advertiu que o rumor da presença de guerrilhas poderia frear os investimentos que adviriam com a formação do bloco econômico. Segundo seus cálculos, uma eventual repressão poderia ser melhor pensada depois que o Tratado de Livre-Comércio estivesse em vigor. Com isso, González foi à mídia enfatizar que não havia hipóteses de existir guerrilhas em Chiapas. A repercussão do evento acabou não sendo tão grande como poderia se esperar, embora alguns veículos de informação, como a revista Proceso e o La Jornada tivessem publicado reportagens sobre o tema entre os meses de junho e agosto de 1993. Nas palavras de García de León: “já era impossível ocultar os fatos. Mas os governantes mexicanos calcularam mal e preferiram guardar silêncio para

\footnotetext{
${ }^{176}$ WOMACK, 1999, p.182.

${ }^{177}$ Antes haviam sido descobertos outros dois acampamentos, mas com repercussão muito menor: em 1988, em Avallanal; e em 1991, em Sabanilla. A descoberta de 1993, no entanto, foi a única em que o governo realmente passou a se preocupar, ainda que com a decisão de não tomar providências imediatas.
} 
não assustar seus superiores, o governo dos EUA, e não colocar em perigo o NAFTA". Outros fatores também pesaram para a decisão de não intervir militarmente em Chiapas: 1) a sucessão de Salinas, nas eleições do ano seguinte, poderia se complicar; 2) 1993 marcava o aniversário de 25 anos do "massacre de Tlatelolco" e certamente provocaria protestos. Salinas, então, mandou Donaldo Colosio, ministro responsável pelo PRONASOL e presidenciável pelo PRI, anunciar compromissos de 50 milhões de pesos em programas para a região. Em setembro do mesmo ano, o presidente inaugurou um hospital com fundos federais.

Dispostos a guerrear, os membros do CCRI, contudo, não podiam autorizar qualquer operação militar que se desenrolasse antes da época de colheita do milho, que aconteceria em novembro. ${ }^{178}$ No dia 17 , já no fïm desse mês, em comemoração aos dez anos da fundação do EZLN, o ânimo tomou conta dos guerrilheiros, que passaram a falar em começar a guerra em semanas. No mesmo dia, o congresso dos EUA aprovou o NAFTA para entrar em vigor no dia $1^{\circ}$ de janeiro de 1994. Começaram, então, a deliberar o dia exato do levante ${ }^{179}$ : a ideia inicial era atacar no dia 12 de outubro, dia de Nossa Senhora de Guadalupe, aproveitando-se da vulnerabilidade de todos estarem participando das festividades. Chegaram a cogitar o dia do Natal e o "dia dos inocentes" (28 de dezembro, algo próximo ao "dia da mentira" brasileiro, mas desistiram da ideia justamente porque, aos cidadãos chamaram a polícia e espalharem a notícia dos ataques, poderia ser encarado como brincadeira, o que demoraria até que se comprovasse veracidade e repercutisse nacionalmente). Por fim, escolheram a virada do dia 31 de dezembro de 1993 para o dia $1^{\circ}$ de janeiro de 1994, que além de ser o marco do início do NAFTA, continha um notório elemento surpresa, uma vez que as comemorações de ano novo iriam ocupar lugar central nos afazeres da população.

O Major Moisés fez um balanço do que foram esses primeiros dez anos na clandestinidade para preparação da insurreição zapatista dizendo que "adquirimos muitas habilidades, experiências, ideias e modos de nos organizar". ${ }^{180}$ Como pudemos observar, o período foi de grandes transformações e aprendizados também para Marcos, em um processo de amadurecimento político, intelectual e de liderança em um contexto

\footnotetext{
${ }^{178}$ WOMACK, 1999, p.42.

${ }^{179}$ Womack (1999, p.43) alega que, nas últimas semanas antes da insurreição, houve algumas migrações forçadas de pessoas contra a guerra pelo EZLN.

${ }^{180}$ RAMIREZ, 2003 , p.76.
} 
de fragilidade dos projetos políticos de esquerda. O EZLN se mostraria para o mundo no dia $1^{\circ}$ de janeiro de 1994 denunciando a marginalização, a pobreza e a opressão a que estariam submetidos ao longo da história. Conforme destaca García de León:

eles [zapatistas] não se deixaram embalar, como todos nós, pelo triunfalismo salinista. Souberam retomar criativamente a demanda democrática nacional, que vinha desde a macrofraude de 1988, apostando na relativa debilidade do sistema. Perceberam que existia uma faixa de debilidade e que era ali que se devia golpear, criando um efeito multiplicador que a oposição pacífica já não era capaz de obter e enviando, ao mesmo tempo, uma espécie de míssil terra-ar que acertou em cheio uma janela do Palácio de Los Pinos. ${ }^{181}$

${ }^{181}$ In: FUSER, 1995, p.131. 


\section{O Rei está Nu!: A Construção do Mito Subcomandante Marcos}

"Everything can change on a New Year's Day" Rage Against the Machine, "War Within a Breath", 1999

Acreditamos que as leituras a respeito dos temas atinentes a essa terceira parte de nossa pesquisa acabaram nos aproximando de nossas hipóteses iniciais. Desenvolveremos, abaixo, os argumentos e interpretações da historiografia em que nos ancoramos para afirmar o caráter em que o messianismo - enquanto manifestação romântica - despertado pela figura do Subcomandante Marcos se concilia justamente com o conteúdo da proposta utópica zapatista.

A revisão da literatura (primária e secundária) nos colocou defronte elementos fundamentais para compreensão do caso, como o significado da máscara (do desmascaramento, inclusive), a teatralidade do Subcomandante e suas múltiplas representações imagéticas (assumidas por si e pelos seus interlocutores). É difícil de observar de modo desarticulado cada um dos termos, já que se imiscuem e se confundem constantemente em uma trama dinâmica e complexa de inter-relações.

De modo geral, o $1^{\circ}$ de janeiro de 1994 no México configurou-se como a primeira denúncia da nova ordem, do ponto de vista de suas vítimas, ao perguntarem quem está realmente mascarado: os que lutaram por sua identidade ou os que se esconderam nos círculos do poder? ${ }^{182}$ Assim, a data irrompeu simbolicamente o terceiro milênio no país, ${ }^{183}$ ao desvelar a verdadeira cara do México: injusto, violento, atrasado. $^{184}$

Enquanto o presidente Carlos Salinas comemorava o ano novo no Palácio de Los Pinos, por volta da meia noite e meia, aproximadamente 900 rebeldes zapatistas tomaram a cidade de San Cristóbal de las Casas, ocuparam o prédio da prefeitura e da Polícia Federal, queimando os documentos oficiais nos arquivos, e invadiram a cadeia pública, libertando todos os presos. ${ }^{185}$ Ao longo da madrugada, outras cidades foram

\footnotetext{
${ }^{182}$ HAYDEN, 2002, p.4.

${ }^{183}$ CECEÑA, 2001, p.92.

${ }^{184}$ FUSER, 1995, p.43.

${ }^{185}$ Entre o primeiro e o segundo dia de levante, libertaram 240 presos em quatro cidades.
} 
dominadas pelo Exército Zapatista de Libertação Nacional. Conforme nos apresenta Tello Díaz, estima-se que entre 2500 e 2900 combatentes tenham participado da ação: aproximadamente 900 em San Cristóbal de las Casas; 600 em Ocosingo; 600 em Las Margaritas; 400 em Altamirano; 300 em Oxchuc e 100 em Chanal. ${ }^{186}$

O EZLN declarou "guerra ao governo supremo" e evocou o artigo 39 da Constituição Mexicana parta justificar sua luta, o qual concedia ao povo "o direito inalienável de alterar ou modificar a forma de seu governo". ${ }^{187}$ Além disso, apresentou um programa político contendo onze demandas, ${ }^{188}$ depois publicado em um jornal chamado El Despertador Mexicano, que entraria para a história como a "Primeira Declaração de Selva Lacandona".

Segundo Nick Henck, o companheiro Felipe estava designado para fazer as relações públicas do movimento e o Subcomandante Marcos chegou à praça de San Cristóbal de las Casas quando aquele havia acabado de ler a declaração aos presentes; no entanto, não demorou para que Marcos assumisse tal função. No mesmo dia, apareceu na varanda da prefeitura e chamou para si os olhares da multidão. Quando da segunda entrevista coletiva concedida pelo EZLN, Felipe já estava eclipsado pelo Subcomandante Marcos. ${ }^{189}$

Marcos insistiu nas várias entrevistas que deu nos primeiros dias que era um subordinado - um subcomandante - às ordens dos indígenas, como era o caso do próprio Felipe. O Subcomandante respondeu de modo cortês, com simpatia, bom-humor e ironia as perguntas dos turistas e jornalistas, em espanhol, inglês e francês, o que surpreendeu e acabou por criar logo de início a percepção de que não eram selvagens. ${ }^{190}$ Carregando uma metradalhora Ingram, mais alto e com pele mais clara que os demais, sua figura despertou a curiosidade das pessoas que estavam em Chiapas por não parecer pertencer às comunidades locais. Ele fez questão de descer até um grupo de aproximadamente 400 turistas (San Cristóbal de las Casas é famosa pelo turismo às

\footnotetext{
186 TELLO DÍAZ, 1996, pp.13-22.

${ }^{187}$ No texto constitucional: "A soberania nacional reside essencial e originalmente no povo. Todo poder público emana do povo e se institui em benefício dele. O povo tem, todo o tempo, o inalienável direito de alterar ou modificar a forma de seu governo".

${ }^{188}$ Quais sejam, trabalho, terra, teto, alimentação, saúde, educação, independência, liberdade, democracia, justiça e paz.

${ }^{189}$ Felipe morreria horas depois num combate em Rancho Nuevo.

${ }^{190}$ FUSER, 1995, p.51.
} 
ruinas de Palenque e Bonampak) e esclarecer questões do levante. Ao dono do Hotel Santa Clara, afirmou que no dia seguinte seriam concedidos salvo-condutos a todos que desejassem sair da cidade. ${ }^{191}$ Com a cidade tomada, um guia turístico advertiu sobre a necessidade que tinha de levar turistas até Palenque, e ouviu a resposta que viria a ficar célebre: "Disculpen las molestias, esto es una revolución". Quando indagado pela Reuters sobre o levante e o EZLN, o turista britânico Peter Morris declarou que "os rebeldes são legais, mas acho melhor sair daqui antes que os soldados cheguem". ${ }^{192}$

A cada dia que passava, Chiapas recebia mais correspondentes estrangeiros. $\mathrm{O}$ tratamento da mídia mexicana no primeiro dia foi de minimizar o ocorrido, escondendo a declaração de guerra (que, inclusive, deixava clara a intenção de fazer o EZLN chegar até a capital do país) e a troca de tiros, afirmando ser um grupo pequeno e com reivindicações restritas. A estratégia era a de retratar o levante como algo menor e de fácil resolução. A primeira declaração do governo central mexicano foi feita pelo subministro do interior Ricardo García Villalobos, em que reconhecia a validade das demandas dos rebeldes, ainda que ressaltasse que a administração Salinas tinha empreendido grandes esforços para melhorar a situação de Chiapas. Igualmente, o governo tentou restringir o conflito a uma dimensão local.

De qualquer maneira, nos primeiros dias

são enviados a Chiapas vinte mil soldados, mais de cem tanques, quarenta aviões, dezenas de helicópteros. (...) guerrilheiros mobilizados na ofensiva eram 2,2 mil, aproximadamente, dos quais apenas duas centenas empunhavam fuzis. Outros mil tinham espingardas de vários tipos. Calcula-se que quatro mil zapatistas permaneceram na mata, para ações de retaguarda. ${ }^{193}$

No segundo dia, as forças zapatistas começaram a retirada e, para tanto, atacaram uma base militar em Rancho Nuevo, sede da $31^{\mathrm{a}}$ zona militar, no intuito de dar cobertura aos rebeldes. As piores batalhas travaram-se na cidade de Ocosingo, onde as tropas militares chegaram a mais de três mil homens. O governo bloqueou as estradas e chegou a San Cristóbal de las Casas na tarde do dia 2 de janeiro, quando descobriram que o EZLN havia sequestrado o ex-governador Absalón Castellanos. Entre o quarto e o

\footnotetext{
${ }^{191}$ FUSER, 1995, pp.55-56.

${ }^{192}$ HENCK, 2007, p. 205.

${ }^{193}$ FUSER, 1995, p.51.
} 
quinto dia de conflito, mais de 3000 soldados do $75^{\circ}$ batalhão de infantaria tomaram conta de San Cristóbal de las Casas; paralelamente, o subministro do interior Ricardo García Villalobos leu uma declaração áspera, que repercutiu mal entre a opinião pública. É importante lembrar um dia antes, os soldados haviam lutado com zapatistas no mercado de Ocosingo: repórteres de todo o mundo atestaram a quantidade de mortos, alguns civis, incluindo cinco zapatistas fuzilados de mãos amarradas. ${ }^{194}$ O governo falava sobre interesses estrangeiros na formação do EZLN, alegando ligações com grupos guerrilheiros da América Central.

Do ponto de vista militar, a contraofensiva do governo foi bem sucedida, mas, do ponto de vista político, mostrou-se desastrosa; ${ }^{195}$ a mídia internacional cobriu o levante, de modo geral, com um tom desfavorável às autoridades governamentais, destacando a situação social de vulnerabilidade do Estado de Chiapas. No dia 6 de janeiro, contudo, o EZLN lançou um comunicado fazendo um balanço dos cinco dias de enfrentamento, exaltando as vitórias obtidas no campo militar. O governo central, por sua vez, substituiu Patrocinio González, ministro do interior e ex-governador de Chiapas, por Jorge Carpizo, ao mesmo tempo em que bombardeou a Selva Lacandona o que gerou uma moção de condenação da Anistia Internacional em Londres - e tentou vincular o EZLN às velhas guerrilhas latino-americanas, plano que não conseguiu durar muitos dias. Formou-se a Compaz, uma associação de organizações civis com a finalidade de pôr fim aos conflitos. nessa esteira, o EZLN colocou as condições para a negociação nos seus próprios termos. No mesmo dia, o presidente Salinas fez o primeiro comunicado a respeito do movimento e chamou Marcos de "usurpador y vendepatrias".

Além do conflito militar, o Subcomandante Marcos e o presidente Carlos Salinas de Gortari deram ensejo a uma disputa no imaginário social mexicano: o primeiro, desde a primeira entrevista concedida, reivindicava para si e para os rebeldes a imagem e a retórica de Emiliano Zapata. De mesmo modo, historicamente Salinas tentava vincular o líder da Revolução Mexicana à sua figura, batizando, por exemplo, o avião presidencial de Emiliano Zapata. ${ }^{196}$ Com efeito, Marcos e os indígenas mascarados conseguiram mais facilmente vencer a batalha simbólica pela herança revolucionária.

\footnotetext{
${ }^{194}$ RAMIREZ, 2003, p.108.

${ }^{195}$ FUSER, 1995, p.56.

${ }^{196}$ Ironicamente, Salinas anunciou a reforma do artigo 27 à frente de um quadro de Zapata. Ainda, a título de curiosidade, o presidente deu o nome para seu filho de Carlos Emiliano.
} 
Como lembra Oppenheimer, ${ }^{197}$ em um país em que até o presidente Salinas louvava Emiliano Zapata, não seria difícil para os auto-intitulados zapatistas ganharem um golpe no terreno das relações públicas.

E, paralelamente a isso, começaram as especulações de quem seriam os líderes do EZLN. Já no dia $1^{\circ}$ de janeiro, a rede Televisa afirmou que Marcos seria o Padre Pablo Romo, líder do Centro de Direitos Humanos Frei Bartolomeu de las Casas. Uma semana depois sustentou que seria o Padre Gerónimo Hernandez Lopez, jesuíta que havia trabalhado em Chiapas até 1992. Nas semanas subsequentes, a rede de televisão continuava o denunciando como sendo parte da Igreja Católica. As conjecturas, segundo Henck, ${ }^{198}$ tinham como principio atacar a guerrilha e dar descrédito à Igreja (mais especialmente ao bispo Samuel Ruiz), pois esta última havia sido explicitamente contraria as reformas do governo central em Chiapas. Ainda no mês de janeiro, Marcos foi declarado morto; depois da retificação, foi capturado como sendo o agitador forasteiro Marcos Rojas, revolucionário mexicano que tinha lutado na Nicarágua com os sandinistas; todas essas histórias faziam o mito acerca de sua figura crescer cada vez mais. O Subcomandante Marcos, desde o início, aproveitou seu carisma para sustentar o interesse da mídia em Chiapas e nos zapatistas - o que se transformava rapidamente no culto a Marcos. ${ }^{199}$

Nos 10 primeiros dias, Marcos escreveu 9 comunicados; no dia 10, publicou no La Jornada um comunicado com vistas a esclarecer ponto-a-ponto questões que vinham sendo disseminadas pela mídia. No dia 11, o EZLN publicou uma explicação de seus princípios políticos, explicitando seu caráter não-partidário e a busca geral por justiça, liberdade e democracia. A opinião pública nacional já nos primeiros dias os percebeu como pobres indígenas e não como guerrilheiros comunistas ${ }^{200}$ : em pesquisa do dia 7 de janeiro, $61 \%$ dos residentes da Cidade do México apoiavam os objetivos zapatistas. Em meados de fevereiro, o número subiria para 75\%. Uma série de manifestações contra os conflitos ocorrem dentro e fora do México. De modo drástico, a União Europeia pressionava pelo fim dos conflitos, sob a ameaça de suspender tratado recém-negociado com o país. Considerando todos esses elementos, Salinas ordenou um cessar-fogo

\footnotetext{
${ }^{197}$ OPPENHEIMER, 1996, p.29.

${ }^{198}$ HENCK, 2007, p.214.

${ }^{199}$ Ibidem, p.216.

${ }^{200}$ Ibidem, p.219.
} 
unilateral no dia 12 de janeiro de 1994 - fechando um período em que a cobertura da imprensa, segundo Grange e Rico, ${ }^{201}$ foi mais intensa do que a de 30 anos de conflitos na Colômbia ou na Guatemala.

Como parte do movimento de recuo do governo central, o presidente Salinas ordenou a destituição do governador de Chiapas, Elmar Setzer, e nomeou Manuel Camacho Solis, ex-prefeito da Cidade do México, para as negociações de paz enquanto representante do governo federal. O EZLN aceitou a proposta de diálogo e propôs a mediação do bispo Samuel Ruiz, o que foi aceito.

A transição do EZLN da arena militar para a politica foi bastante rapida, perfazendo-se em torno de três semanas. A mudança do papel do Subcomandante Marcos foi igualmente patente:

\begin{abstract}
Assim, em menos de 3 semanas freneticamente ocupadas, Marcos abandonou seus próprios sonhos de se tornar um heroi guerrilheiro revolucionário e, reagindo à resposta geral do público à revolta, começou a explorar um papel alternativo, tanto para si mesmo como para o movimento. Ele e o EZLN prepararam-se durante uma década para seguirem um papel predominantemente militar. Agora, de última hora, eles optaram por um papel predominantemente político. Poucos políticos e militares abandonaram tão rapidamente uma ação já em curso, perseguido com tanta intensidade, por tanto tempo, com um custo pessoal tão alto para se adaptar, rever e rejeitar suas estratégias quando confrontados com a realidade de que eles eram obsoletos (tradução nossa). ${ }^{202}$
\end{abstract}

Conforme Igor Fuser, ${ }^{203}$ o período de trégua deu frutos, de tal modo que uma das consequências foi a libertação do ex-governador Castellanos, solto 45 dias depois e entregue a Samuel Ruiz, em uma cerimônia que virou propaganda política do EZLN:

\footnotetext{
${ }^{201}$ GRANGE e RICO, 1998, p.382.

${ }^{202}$ Henck, 2007, p.224. Thus, in less than 3 frenetically busy weeks, Marcos abandoned his own personal dreams of becoming a revolutionary guerrilla hero and, reacting to the general public's response to the uprising, began to explore an alternative role both for himself and for the movement. He and the EZLN had been gearing themselves for a decade toward a predominantly military role. Now, almost overnight, they opted instead for a predominantly political one. Few politicians and military men have abandoned so rapidly a course of action pursued so intensely, for so long, at such a high personal cost to adapt, revise, and reject their strategies when faced with the dawning realization that they were obsolete.
}

${ }^{203}$ FUSER, 1995, pp.62-63 
Castellanos tinha sido condenado a prisão perpétua, num julgamento revolucionário, por ter cometido 'crimes contra o povo'. Ao libertá-lo, o EZLN anuncia que decidiu 'comutar' a sentença, para condenar o réu 'a viver até o último de seus dias com a vergonha de ter recebido o perdão e a bondade daqueles a que por tanto tempo humilhou sequestrou e roubou'. Dom Samuel desenha, com cinzas, uma cruz na testa do homem que prometeu matá-lo.

As negociações de paz tiveram início no dia 21 de fevereiro de 1994, na catedral de San Cristóbal de las Casas. Havia uma incerteza sobre a participação pessoal de Marcos no processo, o que gerou expectativas na sociedade civil. O Subcomandante havia pedido às ONGs ligadas ao tema dos Direitos Humanos para que construíssem um "cinturão de segurança" ao redor do local onde as negociações fossem ser travadas; além de ser uma medida com efeitos concretos, o pedido trazia consigo um elemento de espetáculo para o evento. ${ }^{204}$ Um dia antes - dia 20 de fevereiro -, chegaram ao encontro na catedral 19 delegados do CCRI (7 do comando militar e 12 líderes políticos), com a presença de Marcos confirmada entre eles; 4 da comissão de intermediação e 3 delegados governamentais. ${ }^{205}$

O EZLN apresentou um documento contendo 34 demandas e o clima inicial foi de otimismo, umas vez que Camacho Solís foi respondendo de modo positivo a algumas delas - muito embora o próprio Subcomandante Marcos alertasse que o mero sinal dado nas respostas não garantiria o cumprimento das demandas. ${ }^{206} \mathrm{O}$ negociador do governo central tinha como interesse, de todo modo, restringir a pauta do EZLN, visando atender as demandas regionais sobre os problemas sócio-econômicos de Chiapas, mas tentando obstruir as pautas nacionais, como a deposição de Carlos Salinas, por exemplo.

Muitos autores ressaltam o aspecto profundamente teatral das atividades de negociação na catedral: a mídia registrou a presença de indígenas mascarados, com vestes típicas, bem como o Subcomandante Marcos armado tal como um guerrilheiro, com cartucheiras no peito, fumando cachimbo e desfraldando a bandeira do México ao fim de cada dia de negociação. As rodadas de negociação permitiram, ainda, à imprensa conhecer outros líderes do movimento zapatista, como é o caso de Ana María, esposa de Marcos, e Ramona, que se mostrou também muito carismática.

\footnotetext{
${ }^{204}$ HENCK, 2007, p. 248.

${ }^{205}$ CONDEARENA, 1997, pp.94-96.

${ }^{206}$ FUSER, 1995, pp.163-164
} 
Aproximadamente um mês depois do início das conversas, no dia 23 de março, ocorreu um fato novo, que impactou de modo abrupto nas negociações: o ministro e presidenciável pelo PRI, Donaldo Colosio, foi assassinado. Segundo Castañeda, ${ }^{207}$ a morte de Colosio inaugurou crise política mais grave desde os anos 20 . O ministro vinha dando ênfase a discursos sobre reformas democráticas, de modo que ocorreram conspirações de que setores mais conservadores teriam articulado sua morte. ${ }^{208}$ Segundo Womack, ${ }^{209}$ o assassinato de Colosio pôs por terra o projeto de Salinas - que o havia escolhido via "dedaço", ou seja, pela indicação pessoal do presidente - de reformar o regime priísta por dentro, o que teria desagradado a linha-dura do partido. Ernesto Zedillo Ponce de León, que viria a ser o candidato, no entanto, apresentava-se aos olhos de muitos como alguém despreparado.

O EZLN suspendeu imediatamente as negociações: o CCRI interpretou o ocorrido justamente como resposta dos conservadores a tais pretensões de democratização de Colosio, e acreditavam que o momento se construía como um prelúdio de ofensiva do governo, em comunicado expedido nos dias seguintes à morte. ${ }^{210} \mathrm{O}$ evento gerou questionamentos em Marcos, relatados por ele a Le Bot: se o mando de assassinato poderia ter partido de dentro do próprio PRI, por que aceitariam acordo de paz com rebeldes zapatistas? O Subcomandante Marcos desacreditava das intenções do governo central e afirmou que "a menos que haja mudanças profundas, a oferta do governo será inútil". ${ }^{211}$ Ocorreram pressões da sociedade civil para que os zapatistas voltassem às mesas de diálogo, em um contexto, de repúdio às manifestações de violência. De qualquer maneira, na esteira dos acontecimentos, o EZLN voltou a negociar, ainda que resistissem em largar as armas, uma vez que, segundo o próprio Marcos os "brancos só ouvem indígenas que têm armas na mão". ${ }^{212}$

Paralelamente às negociações, Marcos e o EZLN continuaram tentando se aproximar da sociedade civil, lançando mão de mais comunicados, alguns deles poéticos, reflexões bem-humoradas e até mesmo construções ficcionais. No mês de abril

\footnotetext{
${ }^{207}$ In: FIGUEIREDO, 2006, pp.175-176.

${ }^{208}$ Ibidem, pp.175-176.

${ }^{209}$ WOMACK, 1999, p.45.

${ }^{210}$ Ibidem, p. 176.

${ }^{211}$ OPPENHEIMER, 1996, pp.75-76

${ }^{212}$ LAWRENCE, 1999, p.113.
} 
de 1994, apareceram pela primeira vez no discurso zapatista Votán-Zapata e Durito, o escaravelho. O primeiro é trazido por Marcos em comunicado do dia 10 de abril, data de aniversário de morte de Emiliano Zapata, em que foi apresentado como o deus que estaria por trás do EZLN, a partir do sincretismo maia com a tradição revolucionária. $\mathrm{O}$ segundo - já mencionado na primeira parte deste trabalho como clara referência ao universo quixotesco - apareceu em comunicado do dia 30 de abril, dia das crianças no México, e o personagem simpático serviu, de algum modo, para desconstruir a imagem de caudilho que Marcos poderia trazer consigo. ${ }^{213}$

No que se refere ao andamento das negociações, depois de um amplo processo de consultar as comunidades chiapanecas ligadas ao EZLN, o período de consultas foi declarado encerrado no dia 28 de maio. No dia 10 de junho, o CCRI tornou público o resultado das votações: $2,11 \%$ favoráveis a aceitar as propostas do governo, 97,88\% contrários; desses, 3,26\% votaram que a saída era a volta às hostilidades e 96,74\% defendiam a resistência pacífica. A rejeição aos temos do acordo teve como efeito imediato arrefecer os ânimos de Camacho e mesmo de Ruiz; o primeiro acabou por renunciar ao cargo no governo, alegando divergências com o novo candidato do RPI, Ernesto Zedillo, e o segundo declarou encerrados seus trabalhos de intermediação. ${ }^{214}$

No mesmo dia da divulgação dos resultados, o EZLN lançou a Segunda Declaração de Selva Lacandona, que colocou o intento de buscar maior interlocução com a sociedade civil. A declaração mudou parte dos termos em relação à primeira declaração: falou de sua resistência, explicitou a ideia de "mandar obedecendo" e convocou a todos para a Convenção Nacional Democrática, que seria realizada no mês de agosto de 1994, com o objetivo fundamental de "organizar a expressão civil e a defesa da vontade popular".

De tal maneira que, entre 6 e 10 de agosto de 1994 (datas comemorativas das FLN), ocorreu em Aguascalientes (mesmo nome da cidade em que, reunindo-se no Teatro Morelos, teve início a Soberana Convenção Revolucionária em 1914), na selva Lacandona de Chiapas, a referida convenção, primeiro encontro entre a sociedade civil e o EZLN. Esse realizou uma parada militar e tentou mostrar a realidade dura dos habitantes do Estado. O evento acabou servindo no conjunto, segundo Henck, para

\footnotetext{
${ }^{213}$ FIGUEIREDO, 2006, pp.177-178.

${ }^{214}$ Ibidem, pp.181-182.
} 
cristalizar o culto a Marcos, em que se pese todo o simbolismo daquele local e dos discursos proferidos, tal como o de abertura:

Aguascalientes, Chiapas, um quartel, um bunker, uma fábrica de armas, um centro de treinamento militar, um armazém de explosivos. Aguascalientes, Chiapas, a Arca de Noé, a Torre de Babel, o barco selvático de Fitzcarraldo, o delírio do neozapatismo, o

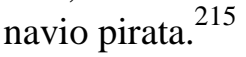

Algumas semanas depois, os mexicanos iriam às urnas para escolher o sucessor de Carlos Salinas. O cálculo de Marcos era de que o resultado seria favorável aos zapatistas, ponderando que se fossem eleições livres e justas, o PRI perderia; se fossem eleições manipuladas, haveria grande reação popular. ${ }^{216}$ O PRI entra na disputa com o já mencionado Ernesto Zedillo, o PRD com Cuauhtémoca Cárdenas e o PAN com Diego Fernandez de Cevallos. A campanha de Zedillo se apoiava na retórica do medo, oferecendo o candidato como o único capaz de garantir a paz social e política no México. $^{217}$ Passou a imagem de credibilidade junto aos Estados Unidos e aos investidores estrangeiros, ao mesmo tempo em que vinculava Cárdenas ao caos e à guerra civil, alegando que sua vitória desestabilizaria o país, vinculando-o, inclusive, ao EZLN. Conforme argumenta Castañeda, ${ }^{218}$ a própria Televisa acompanhava a estratégia de marketing priísta, repercutindo de modo bombástico a temática do medo, pelo noticiário intenso dos conflitos na Bósnia e Ruanda, por exemplo. Cárdenas havia se encontrado com o Subcomandante Marcos em maio de 1994 e a fotografia que registrou a ocasião foi amplamente utilizada por partidários do PRD. Por outro ângulo, quando Cárdenas fazia referência ao Estado de Chiapas em comícios, era costumeiro ouvir gritos de "Marcos, Marcos, Marcos!" entre a militância. ${ }^{219}$ Se por um lado o líder da oposição levava sua campanha mais para a esquerda, garantindo apoio das parcelas prózapatistas, por outro lado, intensificava o medo em uma classe-média mais conservadora - mesmo alguns simpatizantes da causa indígena acabaram por optar por um voto mais cauteloso. O resultado do pleito de 21 de agosto decretou a vitória de

\footnotetext{
${ }^{215}$ HENCK, 2007, p.270.

${ }^{216}$ Ibidem, p.263.

${ }^{217}$ Seus dois slogans foram nessa direção: "bem-estar para sua família" e "um voto para a paz".

${ }^{218}$ CASTAÑEDA, 1995, p.113.

${ }^{219}$ HENCK, 2007, p.264.
} 
Zedillo, com 48,7\%; Diego Fernández de Cevallos termina com 25,9\% e Cárdenas com $16,6 \% .^{220}$

No caso das eleições para governador de Chiapas, o PRI lançou a candidatura de Eduardo Robledo, que disputou com Amado Avendaño Figueroa, pelo PRD. Avendaño praticamente adotou a Segunda Declaração de Selva Lacandona como plataforma eleitoral, colocando-se abertamente como pró-zapatista. Ele chegou a sofrer um atentado durante o período eleitoral. O resultado final deu a vitória a Robledo, com $51,1 \%$ e Avendaño ficou com $34,1 \%$, em mais uma apuração com suspeitas de fraude. De tal maneira que o Subcomandante Marcos exigiu que Avendaño fosse reconhecido governante para que negociações fossem retomadas e imediatamente confrontou Robledo, em artigo no La Jornada, em que deu o recado: "de transgressor para transgressor: você superou seu predecessor nessas eleições".

O período pós-eleitoral era marcado pela ambiguidade da luta pacífica e crescente ameaça da violência. No dia 10 de outubro, o EZLN anunciou a ruptura de diálogo com o governo e dois dias seguintes, no dia que marca a chegada de Colombo, ocorreram manifestações pró-Avendaño em Chiapas, contando com mais de 25 mil indígenas em San Cristóbal de las Casas. No mesmo dia, o EZLN declarou zonas autônomas na Selva Lacandona, anunciou Avendaño governador e se negou a pagar impostos a um governo eleito ilegitimamente - daqui pra frente, a questão da autonomia passou a ficar no centro na arena política chiapaneca. ${ }^{221}$ Com efeito, o movimento endureceu e Marcos tornou o discurso mais agressivo, fazendo ameaças de entrar em guerra se Robeldo continuasse no cargo.

A atmosfera de tensões levou o Subcomandante Marcos a convocar o segundo encontro em Aguascalientes, na primeira semana de novembro, evento que, segundo Ross, Collier e Quaratiello, não conseguiu ter a mesma repercussão do primeiro. Ainda no mês de novembro, ocorreram as comemorações da fundação do EZLN, momento que serviu também para que os líderes fizessem um balanço do que vinha sendo aqueles últimos meses de aparição pública pós-levante. Os discursos - que podem ser

\footnotetext{
${ }^{220}$ Em maio, os candidatos se enfrentam em um debate e o candidato do PAN, Diego Fernandez, foi considerado o vencedor. Logo após o evento, ele saltou do terceiro para o primeiro lugar nas pesquisas. $\mathrm{O}$ Nas semanas seguintes, ele desmobilizou sua campanha, o que gerou desconfianças se houve algum acordo com o PRI (FUSER, 1995, p.194).

${ }^{221}$ HENCK, 2007, p.269.
} 
encontrados na compilação "Documentos e Comunicados" - destacaram os avanços e recuos do movimento zapatista; o próprio Marcos fez vários mea culpa, assumindo que, por vezes, havia gerado mais confusão que unidade. ${ }^{222}$ Ao que parece, Marcos vivia um momento de introspeção: sentindo o impacto dos acontecimentos, como a morte de pessoas próximas a ele em combates (como Hugo e Pedro) e o falecimento do Velho Antonio naquele ano. Em uma cerimônia que os maias chamam de "cerimonia de los siete fuegos", Marcos recebeu do Comandante Tacho sete bastões e ouviu as seguintes palavras: "Recibe, pues, el bastón de mando de las siete fuerzas. Llévalo con honor y que no anclen en él las palabras que no hablan los hombres y mujeres verdaderos. Ya no eres tú, ahora y desde siempre eres nosotros" ${ }^{223}$. A cerimônia foi uma das mais marcantes da história do neozapatismo. ${ }^{224}$

O dia $1^{\text {o }}$ de dezembro de 1994 marcou a posse de Ernesto Zedillo e o Subcomandante Marcos respondeu imediatamente ao discurso feito na ocasião, apontando, por exemplo, que o ministério formado era idêntico ao de Salinas. Publicou o comunicado "Bem-vindo ao Pesadelo", cheio de expressões fortes e retórica bem construída, do qual esse trecho é ilustrativo:

vocês devem desaparecer, não só por representarem uma aberração histórica, uma negação humana e uma crueldade cínica; devem desaparecer também porque representam um insulto à inteligência. Vocês nos fizeram possíveis, nos fizeram crescer. Somos seu outro, seu gêmeo siamês. Para desaparecermos, devem desaparecer vocês. ${ }^{225}$

E, nessa esteira, o EZLN declarou 30 municípios autônomos "em rebeldia", cada qual com suas próprias autoridades. No dia 8 de dezembro, se daria a posse dos governadores estaduais, mas Avendaño ainda se recusou a reconhecer a derrota em Chiapas. A situação de radicalidade fez com que Marcos reconsiderasse a necessidade de voltar à luta armada, ainda que soubesse que situação militar do EZLN seria

\footnotetext{
${ }^{222}$ HENCK, 2007, p.271.

${ }^{223}$ Antes, Tacho explicou: "Siete fuerzas: tzotzil, tzeltal, tojolabal, chol, mame, zoque y mestizo. Que siete veces siete crezca la lucha. Siete palabras y siete caminos: vida, verdad, hombre, paz, democracia, libertad y justicia. Siete caminos que dan fuerza al bastón de mando de jefe de los hombres y mujeres verdaderos".

${ }^{224}$ VARGAS, 2006, p.303.

${ }^{225}$ In: FIGUEIREDO, 2006, p.202.
} 
desfavorável, a partir da constatação de que enfrentavam um impasse e resultados obtidos eram esparsos. Nesse contexto, o bispo Samuel Ruiz anunciou greve de fome, no dia 19 de dezembro, tentando impedir risco de guerra (e outros seguiram seu exemplo, tal como a atriz Ofelia Medina). No dia 23, o presidente destacou a subministra do interior, Beatriz Paredes, para ir a Chiapas negociar. No dia 26, Zedillo reconheceu a Comissão Nacional de Intermediação (CONAI) e destacou a importância de Ruiz para paz, de modo que a greve de fome do bispo terminou no dia 4 de janeiro de 1995.

O presidente Zedillo anunciou a desvalorização do peso no dia 20 de dezembro e associou, contudo, os problemas econômicos aos zapatistas, dando início a uma campanha para deslegitimar sua luta. O ministro da economia, Jaime Serra, foi forçado a renunciar no dia 29 e já no dia 3 de janeiro de 1995 o FMI mandou uma delegação ao México, fazendo recomendações macroeconômicas, a partir do ponto de vista neoliberal, para conter a crise financeira que se iniciava.

As comemorações de ano novo de 1995 foram marcadas por paradas militares e festas com mais de 300 zapatistas mascarados em Chiapas. O comando do EZLN anunciou um cessar-fogo unilateral de 6 dias, que seria estendido até dia 12 e depois declarado indeterminado após dia 16. O dia $^{\circ}$ de janeiro de 1995 também foi a data de lançamento da Terceira Declaração de Selva Lacandona, em que o EZLN trouxe um balanço do primeiro ano após o levante e anunciou um novo plano estratégico, a partir do qual sinalizava simbolicamente a possibilidade de pegar em armas. ${ }^{226} \mathrm{O}$ discurso tornava-se mais radical, mas visava ampliar os contatos com a sociedade civil.

No dia 12 de janeiro de 1995, o EZLN encontrou-se com o ministro do interior Esteban Moctezuma, representando o governo nas negociações. Os zapatistas reconheceram em comunicado o esforço dos representantes governamentais para encontrar caminhos ao diálogo e declararam uma trégua por tempo indeterminado. Dois dias depois, Zedillo presidiu um acordo político nacional com partidos de oposição pra resolver conflitos pós-eleitorais, que ficaria conhecido como Pacto de Los Pinos. O movimento do Presidente para amenizar crise política contemplava a questão eleitoral de Chiapas (bem como de Tabasco, Estado no qual a eleição do governador, Roberto Madrazo, também era contestada, em favor de Lopez Obrador, do PRD - quem anos

\footnotetext{
${ }^{226}$ FIGUEIREDO, 2006, p. 204.
} 
depois disputaria a presidência da República): propôs a renúncia dos priístas, mas os líderes regionais não aceitaram e protestaram contra Zedillo. No conjunto, o mês de janeiro era de clima de otimismo para situação política do país.

Em contrapartida, o mês de fevereiro viu uma reviravolta nos movimentos do governo central. No dia 5, na comemoração dos 78 anos da Constituição Mexicana, Zedillo foi a TV e enfatizou relação com o EZLN pela via política. No entanto, quatro dias depois, colocou em prática o que seria chamado pelos zapatistas de "a traição de fevereiro". 227 Naquela semana de comemorações, o EZLN havia chamado a terceira convenção, a ser realizada em Querétero, recheada de aspectos simbólicos pensados por Marcos, com a ideia de relegar Zedillo a segundo plano e retirar do presidente e do PRI a reivindicação revolucionária proporcionada pela comemoração da data. ${ }^{228}$ Seus planos, contudo, não sairam como o desejado e Marcos não conseguiu unir as forças de oposição, ideologicamente díspares, fazendo do evento desmobilizado, de tal modo que, segundo Henck, o carisma de Marcos mostrou ter limites. ${ }^{229}$

Na quarta-feira, dia 8 de fevereiro, o mercado de ações mexicano atingiu o nível mais baixo em dezoito meses. Com o pano de fundo da economia, tal data marcou a volteface na estratégia de Zedillo referente à relação com Marcos e o EZLN. Seu plano tinha como objetivo prender líderes do movimento, debilitando as posições militares zapatistas com o intuito de enfraquecer seu poder de barganha ${ }^{230}$ - tudo isso somado aos interesses que uma invasão militar em Chiapas despertava nos banqueiros de Wall Street. ${ }^{231}$ Essa ofensiva militar ficaria conhecida como "Operação Arco-Íris". ${ }^{232}$

A estratégia de Zedillo continha um elemento fundamental, qual seja, os contatos feitos com Salvador Morales Garibay, o já mencionado Subcomandante Daniel. A versão mais corrente é a que sustenta que Daniel teria procurado o governo mexicano para delatar seus antigos colegas de guerrilha; Daniel, no entanto, negou esse fato, dizendo que o serviço de inteligência que teria chegado até ele.

\footnotetext{
${ }^{227}$ FIGUEIREDO, 2006, p.208.

${ }^{228}$ HENCK, 2007, p.280.

${ }^{229}$ Ibidem, p.280.

${ }^{230}$ FIGUEIREDO, 2006, p.211.

${ }^{231}$ OPPENHEIMER, p.281.

232 Segundo Reyes e Zebadúa (1995), além de tudo, a operação tinha como objetivo promover espetáculo que recuperasse imagem do governo, satisfazendo o exército e desviando alguns assuntos de foco incluindo a flagrante crise econômica.
} 
A versão de Oppenheimer defende que o serviço de inteligência mexicano (CISEN) vinha recebendo, ao longo de 1994, cartas com remetente "Javier", que alegava poder ajudar com informações privilegiadas sobre o EZLN, Marcos e os zapatistas. $^{233}$ De início, “Javier" não recebeu resposta, mas, conforme foi soltando algumas informações ainda nas cartas, que coincidiam com o que o CISEN tinha levantado, o governo passou a se interessar. Ao final do ano, com as informações de "Javier", o serviço de inteligência chegou até o Subcomandante Daniel. Localizando-o em Los Angeles, na Califórnia, agentes da Segunda Seção do Exército Mexicano prometeram clemência a ele em troca de maiores informações.

Morales, proveniente de uma família de classe média de Michoacán, trabalhava na UAM no final dos anos 70 e foi a Chiapas, conforme dissemos, em 1985, convidado por um companheiro editor da Consciencia Planetaria para curso de primeiros socorros (que, segundo afirmou depois, era, na verdade, o curso de treinamento de guerrilha das FLN). O curso era conduzido justamente pelo Subcomandante Marcos, a quem ele já conhecia da época da UAM. Conforme mencionamos, a relação dos dois nunca tinha sido tranquila, mas foi agravada com o descoberta do acampamento em Las Calabazas, quando Marcos culpou nominalmente Daniel pelo ocorrido. Após o levante, Daniel foi para Los Angeles, mas, ainda segundo Oppenheimer deixou parte de seus pertences (incluindo documentos do EZLN) na casa de um amigo na Cidade do México. ${ }^{234}$ Oppenheimer levanta a hipótese de que esse amigo seja justamente "Javier", mas não deixa claro se o contato com o CISEN foi a pedido de Morales. Isto poderia dar sentido ao seu argumento de que não havia procurado o serviço governamental - mas que, por outro lado, denotaria alguma ingenuidade ou mesmo falta de inteligência ao deixar os materiais na casa do amigo. Outra hipótese é que Daniel teria "terceirizado" a delação pelo amigo, calculando que provavelmente chegariam até ele.

Pudemos verificar a versão do próprio Morales, em entrevista a Grange e Rico, publicada em Letras Libres em 1999. Os autores afirmam que tentaram contar com o Subcomandante Daniel como fonte para seu livro Marcos: La Genial Impostura, mas não obtiveram resposta. Daniel afirmava que temia represálias. Na entrevista, Morales que se refere ao Subcomandante Marcos quase sempre como "Guillén Vicente" reafirmou que o governo que entrou em contato com ele no fim de 1994 porque, como

\footnotetext{
${ }^{233}$ OPPENHEIMER, pp.235-244.

${ }^{234}$ Ibidem, p.241.
} 
era de se esperar, ele também estava na lista dos procurados pelas autoridades. Disse que simpatizantes de Marcos subestimaram o serviço de inteligência. Nessa entrevista, falou sobre anos anos 80 e alegou que havia sido doutrinado pelas FLN. Sobre Marcos, Daniel afirmou que era um homem dos bastidores da política, que tinha jeito sutil de impor e que, desde aquela época, “já se considerava secretário de Deus”. Relatou, ainda, que Marcos tinha como lema que o EZLN deveria usar o bispo Samuel Ruiz sempre que podiam, manipulando ou ocultando informações. Quando o bispo obstaculizava seus projetos, Marcos pedia que Rodrigo intercedesse, uma vez que tinha proximidade com o clero, pedindo que o Ruiz entendesse o trabalho político da organização.

O plano de Zedillo era o seguinte: na manhã do dia 8 de fevereiro Salvador Morales contaria aos magistrados o que havia contado ao serviço de inteligência; no dia seguinte, o exército avançaria nos campos zapatistas em Chiapas e, simultaneamente, o Presidente da República iria à TV divulgar a identidade do Subcomandante Marcos para depois, esperadamente, anunciar sua captura. Conforme apresenta Oppenheimer, Morales, de fato, declarou aos magistrados mexicanos o que sabia sobre Marcos e sobre o EZLN, no dia 8 de fevereiro, por volta das oito da noite; na manhã do dia seguinte, a ofensiva tem início. Invadiram os campos do EZLN e encontraram o casebre onde vivia Marcos - acharam um passa-montanhas, um cachimbo e pacotes de tabaco, um computador e manuais do Windows, duas obras de Julio Cortázar, livros de John le Carré, Fidel Castro e Che Guevara, e o I Ching, dentre outros livros. ${ }^{235}$ O exército, contudo, não chegou até o próprio Subcomandante Marcos, que havia se movido um dia antes para o interior da selva, segundo Oppenheimer, porque deveria ter sido informado por zapatistas da captura de companheiros das FLN em Veracruz e na capital do país (onde o governo mexicano havia descoberto esconderijo de armas). ${ }^{236}$ A ofensiva destruiu imagem do EZLN enquanto grupo militar, já que Marcos e outros tomaram a atitide de fugir da luta contra o governo. Porém, embora a Operação Arco-Íris tenha capturado outros líderes do movimento como Elisa na capital e Vicente em Chiapas, ela é considerada um fracasso justamente por não ter conseguido pegar Marcos. ${ }^{237}$

\footnotetext{
${ }^{235}$ FUSER, 1995, p.185; HENCK, 2007, p.286.

${ }^{236}$ Vale lembrar que o sistema de comunicação via rádio fazia parte do dia-a-dia do EZLN. Mesmo em muitas aparições públicas, o Subcomandante Marcos é visto com o fone de ouvido e o microfone.

${ }^{237}$ Germán também havia conseguido escapar e ficou foragido até 21 de outubro de 1995, quando foi preso. Seis dias depois, ele foi solto sob a argumentação de que viviam sob anistia.
} 
Ainda que Zedillo não tinha conseguido aprisionar e mostrar para todos Marcos - tal como conseguiu, no Peru, Alberto Fujimori com o senderista Abimael Guzmán, colocado literalmente numa jaula em $1992^{238}$-, o presidente foi à TV ainda no dia 9 de fevereiro, às seis horas da tarde, anunciar a descoberta dos esconderijos com armas em Veracruz e na Cidade do México (enfatizando o caráter violento do movimento) e mostrar para todo o país a identidade do Subcomandante Marcos: Rafael Sebastián Guillén Vicente, 37 anos, professor universitário, oriundo de Tampico. A Procuradoria Geral da República apresentou uma transparência com foto de Guillén e colocou embaixo de sua foto mascarado, para mostrar que partes visíveis, como os olhos, correspondiam. $^{239}$

O Subcomandante Marcos, em entrevista para Le Bot, lembrou que foi depois da chamada "traição de fevereiro" que o movimento zapatista decolou. ${ }^{240}$ A ofensiva militar por parte do governo provocou uma grande mobilização da sociedade civil, que a via como desnecessária. No dia 11 de fevereiro, ocorreram uma série de protestos em todo o mundo, uma demonstração de prestígio internacional que assustou Zedillo. ${ }^{241}$ Manifestações em Barcelona, Berlim, Madri, Paris e em várias cidades italianas e estadunidenses se avolumaram; na Cidade do México, mais de 100 mil pessoas foram a Praça do Zócalo, entoando "Zapata vive, a luta segue!” e “Todos somos Marcos!”. A ofensiva governamental deu munição para o Subcomandante continuar sua guerra de palavras.

Em carta assinada no fatídico dia 9 de fevereiro - e publicada no dia 13 do mesmo mês - respondendo a ligação que o governo faz com FLN, Marcos mandou as autoridades vincularem sua luta, antes de tudo, a diversos outros líderes rebeldes latinoamericano, de tal maneira que estabelecia uma relação memória-política, ${ }^{242}$ incorporando novamente o tom poético aos discursos. Além disso, os destinatários da carta foram sempre os mesmos, qual sejam, os zapatistas, a quem ele foi definindo pela exclusão. Ao final, conforme Guilherme Figueiredo, ${ }^{243}$ Marcos brincou com sua própria

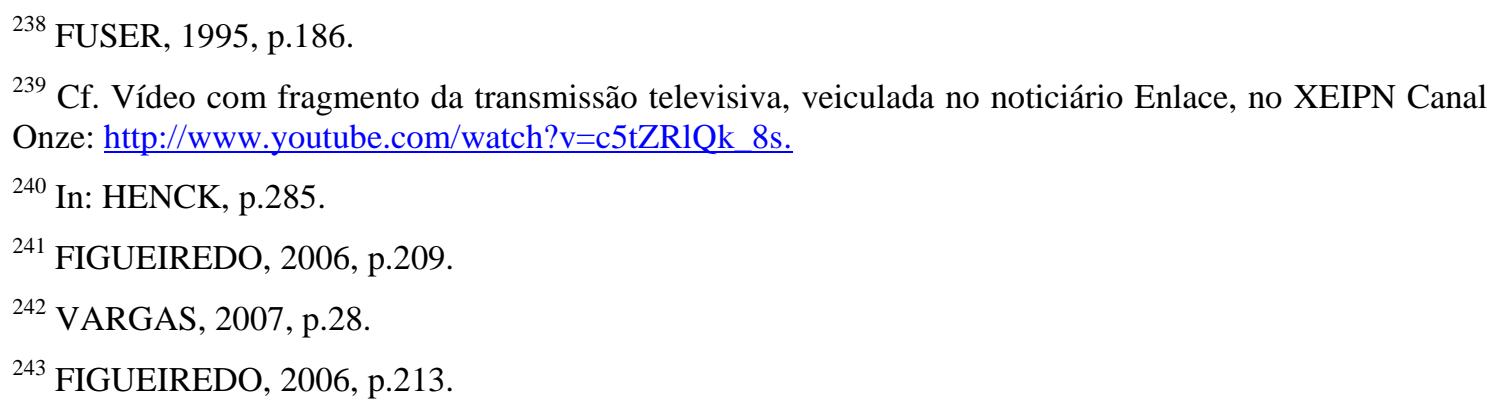


identidade e "traça perfil de si próprio que lembra os heróis do faroeste americanoe o romantismo dos mártires que dão a vida por uma causa". Marcos emitiu um comunicado irônico, com comentários perspicazes sobre sexualidade (perguntando, por exemplo, se o tal Rafael Guillén era bonito, pois não gostaria de arruinar sua reputação com as mulheres). O comunicado irreverente repercutiu a seu favor e ele acabou reestabelecendo suas credenciais de herói fora-da-lei. ${ }^{244}$

Em meio às respostas de Marcos e da sociedade civil internacional, no dia 14 de fevereiro, Zedillo mandou parar a operação, suspendeu a ordem de prisão de Marcos e Germán e pediu para o governador de Chiapas se licenciar do cargo. Ainda, ofereceu mandar um projeto de anistia para o congresso mexicano, que seria aprovado no dia 11 de março. De qualquer maneira, o desmascaramento em si, afinal, pareceu ter sid oalgo eficiente (considerando-se a relação entre custos e benefícios políticos por parte do governo em tomar tal atitude ${ }^{245}$ ). Com a revelação, Marcos acabou saindo dos holofotes da mídia mainstream. ${ }^{246}$

Pudemos verificar que a aparição do Subcomandante Marcos em $1^{\circ}$ de janeiro de 1994 se dá como espécie de epifania: questões ligadas a messianismo, termos como "Deus está dentro dele" (como diz Poniatowska), redenção, revelação e revolução delineiam o aspecto romântico de sua aparição. ${ }^{247}$ Marcos viria trazer a esperança no mundo do "fim da história", ao pregar o sermão de que a utopia não morreu e o México - e toda a América Latina - podem ser as terras da liberdade. Em síntese, Marcos teria vindo pregar a Boa Nova. ${ }^{248}$ Chiapas seria, então, o lugar de encontro da revolução, do

\footnotetext{
${ }^{244}$ GUILLERMOPRIETO, 1995, p.37. Cf. Comunicado assinado no dia 9 de fevereiro: http://palabra.ezln.org.mx/comunicados/1995/1995 02_09 b.htm

${ }^{245} \mathrm{Na}$ mesma linha do caso do plano que a CIA tinha, na década de 60, de fazer cair a barba de Fidel Castro, presidente de Cuba. O efeito de deixá-lo "nu" poderia ser mais eficiente que outra medida mais radical, que poderia gerar desgastes maiores. (Em 1967, Richard Helms, diretor da organização, determinou o abandono desse tipo de operação e ordenou uma investigação sobre o caso, tornada pública em um relatório de 1994).
}

\footnotetext{
${ }^{246}$ STAVANS, 1999, p.391.

${ }^{247}$ COLINA, 1999, p.365.

${ }^{248}$ MEYER, 1999, pp.369-370.
} 
milenarismo e da utopia e o Subcomandante Marcos seria encarado como a mitologia histórica em ação. ${ }^{249}$

$\mathrm{Na}$ verdade, a resistência camponesa e indígena mostrava-se um fenômeno frequente na história regional de Chiapas; em especial, revoltas com características messiânicas ou milenaristas revelavam-se comuns segundo a clássica obra de Antonio Porro, a qual identifica mais de 20 movimentos, surtos ou insurreições com esses traços em terras maias no período colonial. ${ }^{250}$ Conforme lembra o historiador Sebastião Vargas, o messianismo sempre foi meio aglutinador destes camponeses que reagiram coletivamente contra situações de opressão, de tal maneira que "Jesus Cristos e messias, reis e Virgens e constituíram os temas principais dos movimentos de revitalização indígenas entre os maias". ${ }^{251}$ Resgantando essas tradições e incorporando a elas novos elementos, o movimento zapatista reconstruía uma proposta de salvação aos povos indígenas, subjugados "na longa noite de 500 anos". O sociólogo Michael Löwy considera que o EZLN carregava consigo uma dimensão messiânica em seus protestos, com componentes milenaristas, fundamentalmente moderno por seu programa, reivindicações, práticas e formas de organização:

O EZLN nasceu da fusão do guevarismo (que não deixa de ter uma dimensão milenarista) de um punhado de militantes urbanos com a revolta "arcaica" de comunidades indígenas maias e com o messianismo cristão das comunidades de base (fundadas nos anos 70 pelo bispo de Chiapas, monsenhor Samuel Ruiz), sob a égide suprema da legenda milenarista de Emiliano Zapata. O resultado desse explosivo coquetel político-cultural e sócio-religioso foi uma das rebeliões camponesas mais originais dos anos $90 .^{252}$

Na visão de Sebastião Vargas, a religiosidade profunda do povo maia somada à formação de comunidades católicas nas regiões da Selva Lacandona que articularam o discurso da Teologia da Libertação - e onde seria possível fazer germinar a rebelião zapatista - configurava-se como "espaço privilegiado para o aparecimento do "homem

\footnotetext{
${ }^{249}$ MEYER, 1999, pp.370-372.

${ }^{250}$ VARGAS, 2006, p. 187.

${ }^{251}$ Idem, p. 197.

${ }^{252}$ LÖWY, 2010.
} 
novo', de uma 'vida nova', sobre uma 'terra liberta' e do 'reinado de Deus sobre a terra", 253

É importante destacar que a tese de doutorado do historiador Sebastião Vargas contribuiu substancialmente para este trabalho no que se refere, sobretudo, à questão do messianismo, vinculada a movimentos camponeses e/ou milenaristas (o historiador compara o EZLN e o MST brasileiro sob diversos prismas em seu trabalho), apresentando um panorama da literatura que explora o tema. ${ }^{254}$ Segundo Maria Isaura Pereira de Queiroz, em clássico estudo, a concepção popular de messias - e de messianismo - é proveniente do Velho Testamento bíblico, derivação do livro do profeta Isaías, no capítulo 9:

O povo que andava em trevas viu grande luz; os que moravam em terra de sombras da morte, a luz resplandeceu sobre eles. Porque um menino nos nasceu, nos foi dado um filho; traz o governo em seus ombros. Seu nome será Conselheiro admirável, herói de Deus, Padre Eterno, Príncipe da Paz, nascido para restabelecê-la e afirmá-la através do direito e da justiça, desde agora e para sempre. ${ }^{255}$

A questão da justiça mostra-se parte essencial da retórica messiânica, incorporada como fator indispensável à possibilidade de redenção.

No seio da tradição da religião judaica, o messias é o personagem concebido como um guia divino que deve levar o povo ao fim glorioso da humilhação e dos sofrimentos, estabelecendo um reino terreno comparável ao Paraíso na Terra. Se ampliarmos a definição para outras tradições, veremos que o messias é alguém enviado ou "possuído" por uma divindade para trazer a vitória do Bem sobre o Mal, ou para corrigir as imperfeições do mundo, permitindo a inauguração de uma era de maior bem-estar e justiça. Ele é, portanto, um líder religioso e um reformador social.

Subverter a ordem está na essência de suas ações, sendo que alguns se consideram enviados divinos ou mesmo são considerados reencarnações de personagens históricos ou míticos. ${ }^{256}$ No caso do Subcomandante Marcos, parte do processo de culto à sua figura derivava da apreciação de que ele marcaria o renascimento de Che Guevara;

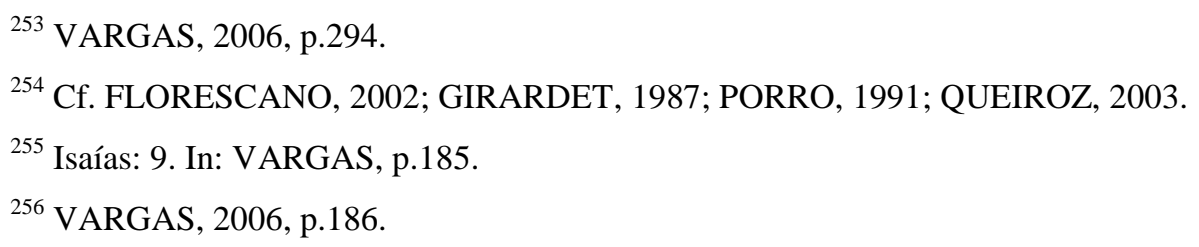


ainda, falava-se que o espírito de Emiliano Zapata estaria por trás do EZLN e informaria as atitudes de seus líderes. ${ }^{257}$ No geral, o dom da oratória é outro traço presente nos líderes messiânicos e, mais do que isso, muitas vezes são considerados "encarnações" do próprio Verbo, como no caso da tradição cristã. Isso vai ao encontro de nossa hipótese inicial de que Marcos, por uma conjunção de fatores, , no plano simbólico, corporificou e deu vazão à promessa utópica zapatista. Além disso, na essência de seus discursos está a ideia de uma nova era de libertação para a humanidade - e o zapatismo apoia-se justamente no ideal revolucionário que permite a construção de uma nova cultura política, em que a emancipação humana se coloque como fim e possa se realizar no horizonte. Tudo isso pelas palavras propagadas de um líder que falava da salvação a partir do sudeste mexicano.

A nosso ver, um ponto fundamental para a compreensão do caráter messiânico em um movimento complexo - porque não essencialmente religioso, ainda que a religiosidade esteja, em boa medida, presente nas bases (ou até mesmo informando as lideranças) - como é o EZLN reside na afirmação de Vargas de que a fé mística não necessita indispensavelmente do sobrenatural para existir. Assim, alimentados pela própria História, para esses grupos "a ideologia substituiria a especulação e a profecia, e a práxis revolucionária se tornaria a verdadeira ascese". 258

De qualquer maneira, de fato, o discurso de Marcos era algo profético e milenarista; ${ }^{259}$ alguns achavam que o Subcomandante Marcos era místico, um enviado que havia desembarcado em Chiapas para preencher profecias. ${ }^{260} \mathrm{E}$ alguns acontecimentos reais ajudavam a fortalecer essa imagem, tal quando na convenção de Aguascalientes, sob forte tempestade, desabou um toldo enorme imediatamente depois que ele terminou seu discurso. Marcos era comparado a Moisés, enquanto príncipe misterioso lançado nas águas e que ressurge adulto, portador de mensagens salvadoras. $^{261}$

Nos comunicados do EZLN escritos pelo Subcomandante Marcos

\footnotetext{
${ }^{257}$ Mesmo no caso da tradição de esquerda mexicana havia gente que pregava que o guerrilheiro Lucio Cabañas não havia morrido, e voltaria para libertar os povos do México.

${ }^{258}$ Ibidem, 2006, p. 265.

${ }^{259}$ Ibidem, 2006, p.336.

${ }^{260}$ GOMEZ-PEÑA, 1995, p.92.

${ }^{261}$ FIGUEIREDO, 2006, p.158.
} 
havia a restauração do romantismo revolucionário, do radicalismo presente na disposição de morrer por uma causa e na recusa de aderir à política institucional e à generosidade cristã, e estes valores vinham conciliados, de certa forma, com os valores então hegemônicos na esquerda: a luta pela via pacífica e por valores democráticos. ${ }^{262}$

Em entrevista a Julio Scherer, o Subcomandante Marcos admitiu caminhar sobre uma linha tênue que explicita as idiossincrasias e contradições do movimento em que era líder, dizendo que "somos un grupo armado haciendo política, y, en ese sentido, arrastramos carencias, errores de criterio, un horizonte muy pequeño, caminando en el filo del mesianismo y del realismo político, algo muy difícil para nosotros". ${ }^{263}$

A figura de Marcos padecia desta contradição: aparecia como o líder carismático de um movimento de resistência complexo - porque sincrético, inovador e até mesmo aparentemente contraditório - em que a ideia de horizontalidade era central. Contudo, o ponto-chave para o entendimento da posição messiânica que Marcos se encontra reside justamente no manejo do conteúdo utópico da proposta zapatista, articulado aos elementos simbólicos trazidos pela figura do Subcomandante, de tal maneira que o caráter messiânico de sua personalidade se desfazia - ou, ao menos, tornava-se flexível.

O uso da máscara conferia aos zapatistas a vantagem do "mimetismo" - sem contar o fato premente de tentarem resguardar a si e a suas famílias ${ }^{264}$ - e conformavam o grande paradoxo do movimento: a máscara virava instrumento de luta pelo direito de serem vistos; era o símbolo mais evidente de revolta contra sua invisibilidade. ${ }^{265}$ É nesse sentido que consideramos que Marcos se transformava, nas palavras de Guillermoprieto, ${ }^{266}$ em um "substituto sem-rosto dos oprimidos". O non-self de Marcos

\footnotetext{
${ }^{262}$ FIGUEIREDO, 2006, p.135.

263 http://palabra.ezln.org.mx/comunicados/2001/2001_03 10_b.htm .

${ }^{264}$ FUSER, 1995, p.51.

265 KLEIN, 2001.

${ }^{266}$ GUILLERMOPRIETO, 1995, pp.37-38.
} 
permitia ser o porta-voz das comunidades, de maneira transparente e iconográfica. ${ }^{267} \mathrm{O}$ recurso pareceu adquirir ainda mais vigor circunstancialmente: desde os tempos précolombianos, os habitantes locais enamoram a máscara e sua identidade enigmática passou a obcecar as pessoas no México e em todo o mundo. ${ }^{268}$ Como afirma Colina, a máscara, como recurso melodramático, tinha impacto na construção da figura do mito: os olhos descobertos revelariam uma pequena janela para ver o homem (Rafael), nulificado pela criação do novo Homem, o Subcomandante Marcos. ${ }^{269}$

A máscara detinha forte apelo simbólico e mostra-se parte essencial de seu carisma, somando-se à sua habilidade pessoal propagandística e irreverência discursiva. Se, de um lado, o uso da máscara lhe conferia uma impessoalidade óbvia, de outro lado, seus comunicados eram tão poéticos e pessoais que acabavam subvertendo a noção de ser anônimo. ${ }^{270}$ Sua cordialidade em entrevistas, derrubava a imagem de rudeza do guerrilheiro: Marcos respondia jornalistas em inglês e francês, com simpatia e bomhumor, o que levava boa parte dos deles - e da opinião pública - a crer, como mencionamos, que os zapatistas não eram "selvagens". 271

De todo modo, a partir do levante de 1994, o aspecto mítico que sua figura adquiriu prevaleceu em relação ao seu fazer pessoal, humanizado. De maneira provocativa, Marcos descrevia a si mesmo, na edição de julho de 1994 da revista francesa Vanity Fair, como um "mito genial",272 - ao usar essa expressão parafraseia de modo provocativo o ministro da economia Pedro Aspe, que havia qualificado a pobreza mexicana nesses termos. Mitificado, o significado de Marcos para os zapatistas atingia uma proporção inesperada. O Subcomandante assemelhar-se-ia a Sísifo, carregando em seus ombros um fardo impossível. ${ }^{273}$ Pois, se Salinas encarnaria perfeitamente a

\footnotetext{
${ }^{267}$ KLEIN, 2001.

${ }^{268}$ STAVANS, 1996, p.388. Vale a pena mencionar também o fascínio provocado pela Lucha Libre entre mascarados no país.

${ }^{269}$ COLINA, 1999, p.364.

${ }^{270}$ KLEIN, 2001, p.117.

${ }^{271}$ No dia do levante, com as estradas bloqueadas, um guia de turismo o questiona sobre a necessidade de continuar levando os turistas aos pontos de visitação em Chiapas (como Palenque) e o Subcomandante responde com a frase que ficaria famosa: "desculpem os incômodos, mas isso é uma revolução".

272 De modo geral, é bastante interessante analisar como fonte documental o já referido filme "A Place Called Chiapas"; em particular, chega a ser engraçado o trecho em que Marcos concede entrevista a essa revista e fica fazendo poses para os fotógrafos com a maior desenvoltura.
}

${ }^{273}$ STAVANS, 1996, p.387. 
contrarrevolução mexicana, ${ }^{274}$ o Subcomandante Marcos parecia resgatá-la e daria a ela novos ânimos.

Com efeito, a figura do Subcomandante Marcos dava início a uma guerra amedrontadora com o governo central praticamente sem armas, utilizando-se das imagens mexicanas mais ressonantes: Zapata, camponeses, dignidade, máscaras etc. ${ }^{275} \mathrm{e}$ ao manejar esse conteúdo simbólico de forma magistral, Marcos acabava colocando o espetáculo no centro da resistência, como sustenta a obra de Figueiredo (2006). ${ }^{276}$

Conforme defende Sebastião Vargas, o mistério da máscara faz parte da mística zapatista. O passa-montanha virava símbolo de resistência ao redor do mundo da nova ordem mundial, de modo que a máscara servia para equalizar e unir todos na luta enquanto um só. ${ }^{277}$ As máscaras zapatistas recriavam uma persona de guerra, assim como as tradicionais pinturas faciais ou corporais para ir à guerra; de modo que, cada vez que o Subcomandante Marcos apareceu, junto dos outros zapatistas, carregavam imageticamente sua luta, afirmando pelo símbolo “aqui resistimos!". ${ }^{278}$ Seu mascaramento expressava uma dinâmica de mudança, uma abertura radical ao futuro. ${ }^{279}$ Além disso, o mascaramento coletivo era o símbolo que une imaginário social indígena e projeto autonomista zapatista.

Mentinis realiza uma discussão de como uso do passa-montanha pode ser entendido em referência a esse imaginário social indígena, ao mesmo tempo em que as máscaras constituiam o meio simbólico para romper com o próprio imaginário, transformando-a no imaginário social zapatista. Além dessa faceta que explorava os limites da cosmologia maia, a máscara do EZLN servia para transcender às identidades individuais, formando-se enquanto força coletiva revolucionária. ${ }^{280} \mathrm{Na}$ linha de José Rabasa,

\footnotetext{
${ }^{274}$ FUSER, 1995, p.35.

${ }^{275}$ GUILLERMOPRIETO, 1995, p.37.

276 Segundo Balandier (1980), em todas as épocas e em todas as sociedades, um dos elementos constitutivos da política é justamente o espetáculo.

${ }^{277}$ CONANT, 2010, p.30 e p.137.

${ }^{278}$ Ibidem, p. 120.

${ }^{279}$ MENTINIS, 2006, p.168.

${ }^{280}$ Ibidem, p.71.
} 
(...) o contingente zapatista inclui, além de Marcos, um número de líderes sin cara e sin nombre - com os noms de guerre do Comandante Tacho, David e Trinidad, e Prefeito Rolando - os quais ainda assim ganharam visibilidade e voz em entrevistas que deram à imprensa. É importante notar que o CCRI-CG tem impedido a participação de Marcos recentemente nas negociações de paz com o governo, de modo a manter em xeque suas tendências ao protagonismo (tradução nossa). ${ }^{281}$

Em comunicados, o Subcomandante Marcos retomava mitos de origem para explicar o uso da máscara; ela remontava aos deuses e tomava um significado poético, de sacrifício, a partir da noção da coletividade se sobrepondo às individualidades. Sua cor negra resgatava o deus Ik' (cujo nome significa "negro" em tojolabal), quem queima a si mesmo como sacrifício; e seu uso, portanto, teria função ritual, ao aproximar os zapatistas daquele sacrifício original. ${ }^{282}$ Dispunhavam-se a morrer literalmente ao irem a combate contra o governo mexicano, ao mesmo tempo em que morreriam simbolicamente ao subtrair sua individualidade na busca pela dignidade humana como um todo. A máscara, de modo geral, expressa ao mesmo tempo o máximo de morte e o máximo de vida. ${ }^{283}$

Os mitos sustentavam o uso e reforçavam os valores do zapatismo, de tal maneira que causavam um terror patológico nas classes dominantes mexicanas - em geral eram associadas ao terrorismo e à criminalidade ${ }^{284}$. Contudo, o uso da máscara também tinha razões práticas: servia evidentemente para esconder-se (ainda que fosse possível perceber os traços individuais pelas partes descobertas - vide que Zedillo, no desmascaramento, sobrepôs a foto do Subcomandante Marcos à de Rafael Guillén, comparando-os) pelo fato de estar quebrando regras. Também serviu para se proteger do frio (San Cristóbal de las Casas está a 2.700 metros acima do nível do mar e em janeiro, época do levante, é inverno no México).

\footnotetext{
${ }^{281}$ RABASA, José. Without History: sulbaltern studies, the zapatista uprising and the specter of history. Pittsburgh: Univ. of Pittsburgh Press, 2010, p.51. (...) the Zapatista contingent includes, besides Marcos, a number of sin cara and sin nombre leaders - with the noms de guerre of Comandante Tacho, David e Trinidad, and Mayor Rolando - who have nevertheless gained visibility and a voice in interviews they have held with the press. It is important to note that the CCRI-CG has kept Marcos from participating in the recent peace negotiations with the government as with keeping in check his protagonist tendencies.

${ }^{282}$ CONANT, 2010, p.125.

${ }^{283}$ BARRAULT, 1961. In: WILLES, 2000, p.148. Sobre a literatura que trata do uso ritual das máscaras no México, Cf. MENESES, Juan Anzaldo, 1996; e MARKMAN e MARKMAN, 1992.

${ }^{284}$ O líder do PAN Diego Fernández de Cevallos, candidato à presidência da República nas eleições de 1994, afirma peremptoriamente que serecusa a dialogar com pessoas usando máscaras.
} 
Marcos alegou surpresa com a repercussão e o debate em torno do uso da máscara. Quando indagado sobre os motivos de cobrirem o rosto, Marcos provocou, com ironia habitual, dizendo que os mais bonitos do grupo decidiram usar para não ofuscar os mais feios. Além disso, ele prometeu que iria por fim a intensa especulação em torno de sua identidade removendo a máscara, desde que sociedade mexicana removesse a máscara de modernidade da qual ela está atrás. Conforme destacam Collier e Quaratiello, a identidade de Marcos tornou-se um passatempo nacional; adivinhar quem estava por trás da máscara do guerrilheiro de repente virou uma obsessão popular. ${ }^{285}$ Uma lista de nomes de quem Marcos era alegadamente foi levantada. Era um assunto que se fazia presente com frequencia em conversas nos lares, no trabalho, em cafés e bares.

Segundo Grange e Rico, o procedimento utilizado pelo governo mexicano no dia 9 de fevereiro de 1995 tinha como objetivo impetrar um golpe psicológico nos simpatizantes; ou ainda, nas palavras de Ross, retirar do Subcomandante Marcos seu poder e mística. ${ }^{286}$ Arevelação das identidades dos líderes zapatistas tentava desfazer a imagem de Marcos como alguém maior que a vida e reduzi-la à de um terrorista comum. ${ }^{287}$ Para Conant, ao mostrar a imagem de Rafael Guillén, o governo de Zedillo esperava remover sua aura mágica de invencibilidade e, com isso, a inteira mística que rodeava o movimento. ${ }^{288}$ No conjunto, almejava-se diminuir o apelo que sua figura tinha.

No evento de Aguascalientes, ocorreu um episódio bastante ilustrativo dos efeitos que sua máscara provocava:

(...) quando Marcos finalmente aparece frente a essa multidão - uma figura solitária com passa-montanha negro - alguém lhe pergunta "Por que esconde seu rosto? O que teme mostrar? Apenas que tem algo vergonhoso a ocultar que esconde seu rosto". Alí mesmo Marcos oferece tirar a máscara. Faz-se silêncio e logo se houve um grito unânime: "Não! Não! Não!". A máscara fica em seu lugar. É um momento crucial na definição de sua imagem. A máscara tem o poder de transformação. (...) É uma imagem transparente, um ícone. ${ }^{289}$

\footnotetext{
${ }^{285}$ COLLIER e QUARATIELLO, 1999, p.4.

${ }^{286}$ ROSS, 2000, p.107.

${ }^{287}$ OPPENHEIMER, 1996, pp.285-286.

${ }^{288}$ CONANT, 2010, p.238.

${ }^{289}$ PONCE DE LEÓN, 2001, p.XXVI.
} 
De qualquer maneira, segundo pondera Nick Henck, o mistério da identidade de Marcos era parcialmente responsável por sua popularidade; seu estilo de vida, personalidade, carisma e, evidentemente, a própria causa indígena se mostraram igualmente significativos. É exemplar a resposta de Marcos a García Marquez e Pombo, quando indagado que "se todos sabem quem ele é, por que usar a máscara?"; ele respondeu dizendo que o que importava é quem o Subcomandante Marcos é e não quem ele foi. Quando afirma "não me importa que venha esse Guillén pra reunião [com o presidente Zedillo], assim seremos três: Zedillo, Guillén e eu", ele assumiu, na visão de Montalbán, o mito em que se transformou, dizendo ainda que "se produz a metamorfose da lagarta Guillén na borboleta Subcomandante Marcos, metamorfose que Marcos vê como renascimento real e deixa no caminho o casulo da lagarta que incubou durante 30 anos". 290

Além disso, sua reação ao desmascaramento passava por respostas irônicas; Marcos brincava nos tradicionais post scriptum de seus comunicados sobre a feiura do novo Subcomandante no dia 13 de fevereiro.

P.S. que aplaude loucamente o novo "êxito" da polícia governamental: ouvi dizer que já descobriram outro Marcos e que é tampiqueño. Não parece mal, o porto é bonito. Me lembro quando trabalhava como segurança em um bordel de Ciudad Madero, na época em que La Quina fazia com a economia regional o que Salinas fez com a Bolsa de Valores: injetar dinheiro para ocultar a pobreza. Fui embora do porto porque a umidade me dá sono e os mariscos o tiram.

P.S. que não abandona, apesar das circunstâncias, seu narcisismo: Bem, e com tudo isso, "esse novo subcomandante Marcos é bonito?". Ultimamente só têm me mandado feios, e isso arruína toda a correspondência feminina. ${ }^{291}$

\footnotetext{
${ }^{290}$ MONTALBÁN, 1999, p.84.

291 P.D. que aplaude a rabiar el nuevo "éxito" de la policía gubernamental: Escuché que ya descubrieron otro Marcos y que es tampiqueño. No suena mal, el puerto es bonito. Me acuerdo cuando estuve trabajando de sacaborrachos en un burdel de Ciudad Madero en la época en que La Quina hacía con la economía regional lo que Salinas hizo con la Bolsa de Valores: inyectarle dinero para ocultar la pobreza. Me fui del puerto porque la humedad me da sueño y los mariscos me lo quitan. P.D. que no abandona, a pesar de las circunstancias, su narcisismo: Bueno, y a todo esto, ¿ese nuevo subcomandante Marcos sí es guapo? Es que últimamente me ponen puros feos y se me arruina toda la correspondencia femenina..
} 
Se por um lado, o desmascaramento de Marcos pelo governo mexicano era bem sucedido ao mostrar a imagem de "homem comum" de Rafael Guillén retirou dele, em alguma medida, o encanto proporcionado pela anonimidade da figura, por outro lado, o projeto era mal sucedido na medida em que gera um "remascaramento": milhares de pessoas vão as ruas para dizer que Marcos era Rafael Sebatián Guillén Vicente, mas que ele simbolizava todas elas. Cria-se, assim, o slogan “Todos somos Marcos!", que entoava que não havia apenas Guillén escondido atrás da máscara, mas uma multidão revolucionária a quem ele teria inspirado desejos fora do mundo indígena. ${ }^{292}$ Conforme o raciocínio de Monsiváis:

\begin{abstract}
"Todos somos índios". O slogan das manifestações é irrepreensível na medida em que expressa orgulho (uma novidade histórica) como componente básico da nacionalidade. Mas o que podemos dizer sobre "Todos somos Marcos"? Essa frase parece demasiado retórica, fruto de paixão militarista, de frenesi romântico ou de uma cenografia messiânica (tradução nossa). ${ }^{293}$
\end{abstract}

Na mesma toada do slogan, Monsiváis ainda diz ao La Jornada que "se condenam a Marcos por querer um mundo melhor e justo, que condenem a mim por querer o mesmo". Segundo Conant, o slogan era uma declaração definitiva de populismo e da idolatria, um apoio quase fanático a Marcos enquanto líder revolucionário e herói cultural. ${ }^{294} \mathrm{O}$ discurso da alteridade ganhou, então, ainda mais força.

Mesmo detratores como Grange e Rico chegam a afirmar que o "Todos Somos Marcos" era o ponto de inflexão na retórica do movimento zapatista, afirmando que "os numerosos seguidores do novo messias sepultaram, porém, os críticos sob uma avalanche de lemas entusiastas que deram a volta no planeta. Um novo lema se impôs: Todos Somos Marcos". Ainda, segundo os autores, "O 'homem novo', quimera dos anos 60, volta à atualidade, depois de ter descoberto sua versão recente da Selva

\footnotetext{
${ }^{292}$ MENTINIS, 2006, p.175. Nas manifestações de fevereiro de 1995, o grito de "Todos somos Marcos!" era respondido pelas colunas feministas com "Ramona somos todas!"; e, com dose de humor, ouvia-se gritos de "Marcos para todas!" (ORTIZ, p.188).

293 In: RABASA, p.37. "Todos somos índios". The slogan of the demonstrations is unobjectionable insofar as it expresses pride (a historical novelty) for a basic component of nationality. But what we can say about "Todos somos Marcos"? This phrase seems too rhetorical, the fruit of militaristic passion, of romantic frenzy or of a messianic scenography.

${ }^{294}$ CONANT, 2010, p.237.
} 
Lacandona". ${ }^{295}$ Na visão de Mentinis, contudo, a máscara chamada de Marcos não é o homem novo, mas o processo que se abre para que o novo homem chegue - é um processo de transformação. ${ }^{296}$ Tal visão coadunava-se com a própria formulação utópica zapatista em "fazer uma revolução para que a revolução seja possível”, aproximando o ideário do movimento à simbologia trazida por seu líder.

A teatralidade - em seu aspecto performático - conferia ao Subcomandante um lugar único. ${ }^{297}$ As múltiplas performances de Marcos, ancoradas no mistério fornecido pela máscara, permitiram a ele representar e ser representado de modo variado (guerrilheiro, novo Che Guevera, caudilho, terrorista, popstar, sex-symbol etc.). Sua figura permitia adaptabilidade: era fácil às pessoas enxergarem nele aquilo que queriam enxergar e identificavam-se nele, como se sua máscara fosse um espelho; ora, segundo Nick Henck se os tempos mudaram, o tipo de liderança mudou de modo equivalente. ${ }^{298}$ O historiador Sebastião Vargas resume bem esses aspectos a serem explorados:

Muito do fascínio exercido pelo chefe guerrilheiro se deve à "multiplicidade" de significados que sua figura alimenta. Como ele mesmo diz, com certa ironia, "sou um mito genial". Geralmente a cavalo, com a indumentária completa: gorro "passamontañas"; cachimbo; uma velha boina estilo Mao Tsé-Tung, com as três estrelas vermelhas e o igualmente gasto (datam de sua primeira estada na selva do fim de 1983) lenço vermelho no pescoço; as imensas cartucheiras a la Zapata (ou Lampião) nos ombros; o aparelho de rádio; um relógio em cada pulso e o moderno fuzil (um M-16, calibre $5.56 \mathrm{~mm}$, com seletor de cadência e alcance efetivo de 460 metros, além de mira telescópica e carregador de tambor com 90 tiros), entre discreto e ameaçador. Sua imagem remete a imaginários diversos, porém poderosos: a do rebelde justiceiro e guerreiro (Robin Hood ou Zorro modernos); a do sábio (cujo atributos são os dons da fala e da escrita e o símbolo mais evidente o cachimbo); a do revolucionárioguerrilheiro que recupera e revitaliza um dos maiores "mitos" latino-americanos do século XX que foi o Che Guevara, isso tudo misturado a uma exótica e misteriosa condição indígena, simbolizada pelo uso dos "bastões de mando" e da máscara, de variados significados na cultura tradicional mexicana. Signo da fusão entre os dois universos, o urbano, culto, marxista e ocidental com o indígena e mítico sem deixar de ser contemporâneo, é a linguagem sincrética do subcomandante Marcos. Atrás da

\footnotetext{
${ }^{295}$ GRANGE e RICO, 1998, p.14.

${ }^{296}$ MENTINIS, 2006, p.175.

${ }^{297}$ Cf. HASS, 2001.

${ }^{298}$ HENCK, 2007, p. 231.
} 
máscara que lhe permite muitas personalidades, juntam-se diferentes estilos literários, linguagens heterogêneas, capazes de produzir textos inclassificáveis pela leveza e rapidez na troca de tom e conteúdo. Neles podemos detectar e analisar uma grande variedade de influências, tradições e ecos. ${ }^{299}$

Logo naquele mês da exposição pública intensa na mídia, o Subcomandante Marcos foi transformado em uma estrela e deu origem ao que seria chamado de "Marcosmania". Logo nas primeiras semanas, a Marcos recebeu na Selva Lacandona uma grande quantidade de jornalistas dos mais distintos veículo de comunicação, tais como, Vanity Fair, Der Spiegel, Cambio 16, Le Figaro, New York Times, San Francisco Chronicle, NACLA - apenas para citar alguns. Nos primeiros meses, recebeu mais de duas mil cartas, com diferentes propósitos (entre elas a carta que ficaria famosa da menina de oito anos que pedia autorização a ela para ser Subcomandanta do movimento). Recebeu, em Chiapas, Oliver Stone, Danielle Mitterand, uma campanha da Benneton PR e Bianca Jagger, entre vários outros nomes famosos.

De modo geral, o Subcomandante Marcos ocupava um lugar central no imaginário pop mexicano - e até mesmo mundial. Em um mês, "Subcomandante Marcos" virou uma nome conhecido nos quatro cantos do mundo; entre fevereiro e abril, era possível, por exemplo, ver adolescentes com máscaras em shows de rock não se traçava uma linha entre a política radical e a cultura pop. ${ }^{300}$ Mesmo anos depois do levante, o Subcomandante Marcos mantinha espaço em esferas da cultura popular: para mencionar alguns exemplos, os discursos e declarações zapatistas declamados com a voz de Marcos foram utilizados no álbum "Clandestino" do músico francês Manu Chao de 1998; até 15 anos depois da insurreição zapatista, a novela Mi Pecado, produzida por Juan Osorio, cujo enredo se desenrola em Chiapas, fez referência a Marcos. O Subcomandante Marcos construía sua própria imagem enquanto heroi popular na tradição de ativistas como Superbarrio, Fray Tormenta, Super-Ecologista, ${ }^{301}$ em um país aficionado pela Lucha Libre e seus famosos praticantes mascarados.

Com o tempo, sua imagem seria disseminada em camisetas, isqueiros, adesivos, relógios, canetas e tudo que pudesse ser vendido como souvenir. A figura de Marcos era

\footnotetext{
${ }^{299}$ VARGAS, 2006, pp.31-32.

${ }^{300}$ GOMEZ-PEÑA, 1995, pp.91-92.

${ }^{301}$ Ibidem, p.90.
} 
fetichizada e o zapatismo, mercantilizado. ${ }^{302}$ Já no mês de fevereiro de 1994, durante as negociações de paz, um jornalista levou até Marcos um preservativo recém-fabricado com o nome provocativo de Alzado (fazendo vínculo criativo com o levante zapatista), o que chegou a provocar descontentamento no Subcomandante.

Um outro aspecto a se destacar era a profunda sexualização da figura do Subcomandante Marcos. Recebia milhares de cartas de garotas que se colocavam à disposição para o conhecer e ser sua companheira. Rapidamente virou um sex-symbol. As imagens do guerrilheiro mascarado, do herói revolucionário, povoavam as fantasias de garotas mexicanas - muitas delas iam a Chiapas e ficavam inebriadas por estarem perto do ídolo. ${ }^{303}$ Chegou-se a lançar uma edição barata do "Kamasutra segundo El Sup". ${ }^{304}$ Nessa esteira, Gomez-Peña lembra de uma peça de cabaré em que aparecia um personagem Marcos e fazia um striptease parcial da máscara; bem como um bar gay de Guadalajara em que se podia notar a presença de um travesti com parte da indumentária do Subcomandante Marcos. ${ }^{305} \mathrm{O}$ autor continua dizendo que Marcos transformou-se em ícone da sexualidade proibida, de tal maneira que mulheres projetavam suas fantasias sexuais nele.

Uma outra faceta a ser explorada na figura de Marcos diz respeito ao humor contido nos comunicados zapatistas. Como afirma Vargas, "o sarcasmo, a irreverência, o humor e a ironia dos textos de Marcos ficam mais evidentes nos posts scripts, os célebres 'P.S.' que o subcomandante usa para mudar o tom dos discursos, adequando-se perfeitamente ao interlocutor, e mandando 'recados certeiros' aos diversos setores da sociedade, do Estado e das forças armadas". ${ }^{306}$ Casos exemplares são a resposta ao ultimato do exército pela rendição dos rebeldes apenas com a interjeição em letras garrafais "UYIII!!!", zombando descaradamente da força dos militares; ou quando emitiu um comunicado contendo exclusivamente expressões de Speedy Gonzales, personagem mexicano da Warner Brothers (conhecido no Brasil como Ligeirinho), como "arriba, arriba", “andalé, andalé” e “yepa, yepa”, em um deboche frontal à

\footnotetext{
302 Cabe mencionar que, até em Chiapas, os indígenas passam a vender a turistas bonecos feitos artesanalmente representando os zapatistas, Marcos, Ramona, Tacho, entre outros.

${ }^{303}$ HENCK, 2007, p.229.

${ }^{304}$ CONANT, 2010, p.243.

${ }^{305}$ GOMEZ-PEÑA, 1995, p.92.

306 BELAUTESGUIGOITIA, 1996, analisa os "P.S." como recurso estilístico de Marcos para compreender significados do discursos zapatista.
} 
autoridades a quem era dirigido o comunicado. Os detratores do zapatista passaram, com o tempo, a desqualificá-lo usando a alcunha subcomediante Marcos.

Se por um lado o culto à personalidade ajudava a manter o EZLN na pauta, por outro lado, tinha efeitos colaterais infelizes. O próprio Marcos discorreu em maio de 95 sobre seu estrelato afetar a causa zapatista em comunicado ao La Jornada, em que defendeu que o EZLN não é apenas o nariz visível, em alusão ao fato de ter um nariz protuberante. ${ }^{307} \mathrm{Em}$ 2001, em famosa entrevista a Julio Scherer, ele proprio afirmou que construíram uma imagem falsa a seu respeito, que interessava a midia. E, em 2008, chegou a declarar que se pudesse fazer algo diferente, teria jogado um papel menos protagonista na mídia. ${ }^{308}$ A problematização que se faz necessária é em que medida o culto a Marcos eclipsou a causa que ele mesmo representa; e em que medida a causa foi justamente explorada pela encorporação propícia à sua figura.

O fato é que o Subcomandante Marcos confirmava seu papel como "mestre do marketing", lançando mão de uma "poética da resistência", expressão que é título do livro de Jeff Conant, utilizado nesta pesquisa. Segundo Grange e Rico, ao contrário de Ernesto Che Guevara (grande ídolo de Marcos), o Subcomandante tinha um temperamento que buscava os holofotes e a notoriedade pública, de modo que, preocupado em manter vivo o herói mascarado, fez esquecer seu outro eu, Rafael Guillén e "multiplica piruetas para ocultar seu passado". 309 E continuam, dizendo que "Marcos confirma o que há muito se suspeitava: seu imenso talento para o teatro e o showbiz não fizeram dele um dirigente responsável”.

Na visão de Marcos, na referida entrevista para Julio Scherer "lo que pasa es que la imagen de Marcos responde a unas expectativas románticas, idealistas. O sea, es el hombre blanco, en el medio indígena, más cercano a lo que el inconsciente colectivo tiene como referencia: Robin Hood, Juan Charrasqueado, etcétera."

É interessante pensar que nos primeiros meses após o levante, por exemplo, Marcos contou diferentes histórias sobre sua origem a cada entrevista que concedia, inventando e reinventando a imagem de si mesmo aos jornalistas, que reproduziram

\footnotetext{
307 O nariz grande faz com que a imagem de Marcos seja vinculada também à de Hercule-Savinien de Cyrano de Bergerac, escritor e duelista francês, conhecido pelos trabalhos de ficção que se tem feito sobre sua vida, em especial a peça de Edmond Rostand. Cyrano de Bergerac é sempre retratado como tendo um grande nariz.

${ }^{308}$ CASTELLANOS, 2008, p.92.

${ }^{309}$ GRANGE e RICO, 1998, p.13.
} 
fielmente cada versão. Conforme Montalbán, "Nenhum jornalista descobriu quem é Marcos realmente, e até que alguém o faça ele continuará a inventar e reinventar a imagem de si mesmo que dissemina aos jornalistas que o visitam. O mistério de Marcos faz com que ele continue sendo assunto de reportagens, apesar de sua grande exposição". 310

Tal suposição parece se confirmar, por exemplo, no episódio que se tornaria famoso em que disse para um repórter do San Francisco Chronicle que havia ido à Chiapas em função de ter sido demitido de um restaurante da cidade de São Francisco, na Califórnia, pelo fato de ser gay. Toda a imprensa mexicana publicou que Marcos teria assumido sua homossexualidade. Com a repercussão da (falsa) informação, Marcos, enfim, respondeu sobre sua identidade:

\begin{abstract}
A tudo isto de se Marcos é homossexual: Marcos é gay em São Francisco, negro na África do Sul, asiático na Europa, hispânico em San Isidro, anarquista na Espanha, palestino em Israel, indígena nas ruas de San Cristóbal, membro de gangue em Neza, roqueiro na cidade universitária, judeu na Alemanha, ombudsman na Sedena [Secretaría de la Defensa Nacional], feminista nos partidos políticos, comunista no pós-guerra fria, preso em Cintalapa [município de Chiapas], pacifista na Bósnia, mapuche nos Andes, professor na CNTE, artista sem galeria e sem portfólio, dona de casa num sábado à noite em qualquer bairro em qualquer cidade de qualquer México, guerrilheiro no México do fim do século XX, grevista na CTM [Confederación de Trabajadores de México], jornalista nas páginas anteriores do jornal, machista no movimento feminista, mulher sozinha no metrô depois das $22 \mathrm{~h}$, aposentado durante um ato no Zócalo, camponês sem terra, editor marginal, operário sem trabalho, médico sem consultório, estudante inconformado, dissidente no neoliberalismo, escritor sem livros e sem leitores e, sobretudo, zapatista no Sudoeste do México. Enfim, Marcos é um ser humano qualquer neste mundo. Marcos é todas as minorias intoleradas, oprimidas, resistindo, exploradas, dizendo ¡Y Ya basta! Todas as minorias na hora de falar e maiorias na hora de se calar e aguentar. Todos os intolerados buscando uma palavra, sua palavra, o que devolva a maioria aos eternos fragmentados, nós. Tudo que incomoda o poder e as boas consciências, este é Marcos. ${ }^{311}$
\end{abstract}

O discurso mostrou estar alinhado com oprimidos do mundo e que Marcos e zapatismo podiam ser quem quiserem e estar onde quiserem. ${ }^{312}$ Ele próprio chegou a afirmar que se fosse capturado, outros surgiriam e o substituiriam ele porque não era uma pessoa, mas sim um ideal. ${ }^{313}$ Mesmo nas ocasiões em que estava em outros lugares do país, O

\footnotetext{
${ }^{310}$ In: HAYDEN, 2002, p.45.

${ }^{311}$ EZLN:Documentos y Comunicados, vol.1, p.234.

${ }^{312}$ CONANT, 2010, p.242.

${ }^{313}$ HENCK, 2007, p.238
} 
Subcomandante Insurgente assinou "das montanhas do sudeste mexicano". Tudo isso apresenta uma conotação de que sua figura paira sobre o espaço e transcende a própria individualidade.

Antonio Cândido provê um excelente resumo acerca do que faz o Subcomandante Marcos enquanto agente político que nasce no bojo da nova ordem internacional; Marcos é um

[...] homem de cultura e de luta, capaz de plantar no meio da argumentação ideológica um soneto de Skakespeare; capaz de juntar à eficiência estratégica do guerreiro tanto o discernimento do político, quanto a eloquência do escritor; que sabe fazer tudo isso sem solenidade convencional, porque são dele o sarcasmo, o bom humor e uma espécie de familiaridade, que torna a sua palavra acessível e alentadora. ${ }^{314}$

"Questionam-nos, dizendo que não temos um modelo. Mas o futuro não se desenha em planos. É inventado no presente. A utopia concreta repousa incansavelmente no chão das resistências e lutas cotidianas. O colapso dos regimes burocráticos, longe de deixar-nos órfãos de modelos, abre o caminho para o futuro"

(Daniel Bensaïd)

"Temos o direito de ser iguais quando a nossa diferença nos inferioriza; e temos o direito de ser diferentes quando a nossa igualdade nos descaracteriza.

Daí a necessidade de uma igualdade que reconheça as diferenças e de uma diferença que não produza, alimente ou reproduza as desigualdades"

(Boaventura de Sousa Santos)

O Subcomandante Marcos e o EZLN, como se sabe, apareceram para o mundo no $1^{\circ}$ de janeiro de 1994 carregando armas e tomando cidades do Estado de Chiapas em um conflito com o governo central que dura doze dias. A partir do dia 12 de janeiro, Marcos e os zapatistas largaram as armas e optaram pela palavra para confrontar as autoridades mexicanas e para descontruir a imagem mexicana - tanto em âmbito nacional como, principalmente, no internacional - de estabilidade e progresso. Muitos analistas levam em conta essa passagem (mesmo no título de suas obras como é o caso,

${ }^{314}$ CÂNDIDO, Antonio. In: BUENROSTRO Y ARELLANO; OLIVEIRA, 2002, p. 49. 
por exemplo, de "The Fire and The Word" de Gloria M. Ramirez, e "Nuestra Arma es Nuestra Palabra", compilação de escritos de Marcos por Juana Ponce de León) e o próprio Subcomandante Marcos apontou que o marco simbólico do nascimento da utopia zapatista se deu no 12 de janeiro de 1994 - e não no $1^{\circ}$ de janeiro, como tradicionalmente se destaca. E aí reside o nexo crucial para o entendimento da passagem de uma proposta vanguardista revolucionária para um complexo movimento indígena de resistência, dentro do qual o Subcomandante Marcos desempenhava papel relevante no plano político, intelectual e simbólico. E, nesse sentido, encaminhamos o estudo, considerando o papel de Marcos, enquanto (anti-)líder no movimento zapatista, de revitalizar os anseios revolucionários, em uma época de utopias em refluxo. E aí, nos pareceu fundamental caminhar nessa interface onde indivíduo e coletividade se (con)fundem, onde a figura do (anti-)líder se relaciona com o projeto utópico em questão.

Para o entendimento do significado do "coquetel explosivo" que forma o zapatismo, utilizamo-nos das contribuições teóricas de Michael Löwy (obras diversas, listadas na seção de referências bibliográficas), na medida em que suas teses parecem se aplicar às faces do movimento, em que pese sua dimensão romântica, em uma época de desencantamento do mundo. Para Löwy, “o zapatismo é um movimento portador de magia, de mitos, de utopias, de poesia, de romantismo, de entusiasmos, de esperanças loucas, de mística - no sentido que lhe dava Charles Peguy, opondo-o à 'política' -, de fé". ${ }^{315}$ Segundo Leite, Löwy anuncia a ideia de que um certo romantismo é um componente fundamental do marxismo revolucionário, funcionando como antídoto para as influências positivistas e cientificistas. ${ }^{316} \mathrm{Em}$ sua análise, romantismo implica em uma revolta moderna contra a modernidade; opõe-se ao desencantamento, quantificação e mecanização do mundo bem como a abstração racionalista e dissolução de vínculos sociais (Idem, p.11), ${ }^{317}$ justamente elementos confrontados pelo EZLN. De modo que na visão de Löwy:

pode-se criticar muitas coisas nos zapatistas (...), mas deve-se reconhecer-lhes este mérito enorme: neste fim de século moroso, de neoliberalismo triunfante, de cinismo galopante, de política politiqueira, de mercantilismo rasteiro, eles conseguiram fazer as

\footnotetext{
${ }^{315}$ LÖWY, 1997, p.199.

${ }^{316}$ In: LÖWY e BENSAÏD, 2000, p.10.

${ }^{317}$ Ibidem, p.11.
} 
pessoas sonharem, em Chiapas, no México, e um pouco em todo o mundo. Eles são os reencantadores do mundo. ${ }^{318}$

De modo geral, avançamos bastante em problemáticas relacionadas à utopia. A obra de Russell Jacoby, em particular, mostrou-se uma excelente referência, ao apresentar um panorama da questão, fornecendo-nos material para aprofundamento no estudo da utopia, particularmente em sua análise de sua inserção quando em tempos de refluxo. ${ }^{319}$ Nesse sentido, Vargas afirma que:

a valorização da utopia (...), num momento onde conjunturas internacionais deixavam as organizações de esquerda sem projeto de futuro e quando formulações teóricas provindas do próprio 'campo socialista' pareciam liquidar qualquer viabilidade de projetos utópicos, é um dos fenômenos da mais alta relevância e que ainda não foi suficientemente estudado. ${ }^{320}$

A veia utópica é reivindicada pelo EZLN, por exemplo, neste comunicado:

Em nossos sonhos temos contemplado um outro mundo. Um mundo verdadeiro, um mundo definitivamente mais justo daquele no qual vivemos agora. Vimos que neste mundo os exércitos não eram mais necessários, que a paz, a justiça e a liberdade eram tão comuns que já não se falava delas como coisas distantes; do mesmo modo, as coisas boas deste mundo eram mencionadas como quem fala do pão, dos pássaros, do ar, da água, como quem diz livro e voz. Neste mundo, o governo da maioria era razão e vontade; os que mandavam eram pessoas de bons pensamentos; mandavam obedecendo. Este mundo verdadeiro não era um sonho do passado, não era algo que vinha de nossos antepassados. Vinha do futuro, pertencia ao passo seguinte que dávamos. Foi assim que começamos a caminhar para fazer com que este sonho se sentasse à nossa mesa, iluminasse a nossa casa, crescesse em nossas plantações, enchesse o coração de nossos filhos, limpasse nosso suor, sanasse nossa história e se tornasse realidade para todos. É isto que queremos. Nada mais, mas também nada menos. ${ }^{321}$

A utopia, em sua acepção contemporânea, nada teria a ver com devaneios; pensar o futuro não implica descartar a atuação na vida cotidiana, ${ }^{322}$ pois, no fundo, cada utopia fala à sua própria época, dialogando com seus referenciais, mas olhando

\footnotetext{
${ }^{318}$ Ibidem, p. 201.

${ }^{319}$ JACOBY, 2001.

${ }^{320}$ VARGAS, 2007, p.120

${ }^{321}$ CCRI-CG do EZLN, $1^{\circ}$ de março de 1994.

${ }^{322}$ JACOBY, 2001, p. 232.
} 
para além deles. Se nos mitos antigos as utopias eram uma espécie de reino milenar ou paraíso futuro, inacessíveis; nas utopias modernas - incluindo as modalidades românticas - os indivíduos esforçam-se para imaginar mundo real acessível, próximo aos homens. ${ }^{323}$ A utopia, pois, enxerga o mundo com um olho no futuro e outro no presente. $^{324}$ De modo que a utopia zapatista, encarnada na figura do Subcomandante Marcos, não fugiria a este esquema: ela propõe um mundo novo "onde caibam vários mundos" e ele representa, no plano simbólico, essa nova cultura de resistência e suas contradições, congregando imageticamente em torno de si todos os "homens sem-rosto" do mundo em que vive. ${ }^{325}$

Ao longo de todo o ano de 1994, as políticas de resposta do governo tentaram conter a influência de Marcos e infantilizar o resto dos zapatistas: questionaram como os indígenas chiapanescos poderiam atribuir ao NAFTA sua insurreição? Como poderiam ter essa consciência ${ }^{326}$. O governo desprezava a força histórica dos indígenas de Chiapas, não reconhecendo que:

A originalidade - e a força - do neozapatismo reside nesta mistura de ideias e indivíduos vindos de fora com as tradições, as formas de organização e a luta dos indígenas de Las Cañadas, o coração da revolta de Chiapas. A rebelião, sem dúvida, não existiria sem Marcos e um punhado de outros ativistas de formação marxista que, oriundos das cidades, começaram a se implantar na região no início dos anos 80 . Tudo o mais, porém, é autenticamente indígena: os combatentes, as bases de apoio, as formas de luta, a linguagem, as bandeiras, até mesmo a direção do movimento. 'o encontro entre esse pequeno grupo guerrilheiro e os indígenas de Las Cañadas se converteu em algo extraordinário: os guerrilheiros se fizeram indígenas e os indígenas se tornaram insurgentes', analisa o especialista belga Jan de Vos, do Centro de Investigações e Estudos em Antropologia Social (...)".327

O zapatismo jaz na questão indígena, mas, conforme o próprio Marcos, evidencia problemas de japoneses, curdos, australianos, catalães, chicanos e

\footnotetext{
${ }^{323}$ SALIBA, 2003, p.103.

${ }^{324}$ SANCHEZ, 2001, p.234.

${ }^{325}$ Cf. vídeo em que Marcos retiraria seu passamontanhas:http://www.youtube.com/watch?v=SaUpcqRm5PA\&feature=related.

${ }^{326}$ RABASA, 2010, p.49. Em nosso título da parte III da pesquisa, evocamos a famosa exclamação de denúncia do menino no conto dinamarquês “As Novas Roupas do Imperador" em certa medida como ironia à relatada infantilização dos povos indígenas pelo governo central mexicano.

${ }^{327}$ FUSER, 1995, p.108.
} 
mapuches. $^{328}$ A utopia zapatista entrelaçava a dimensão local, nacional e global, complicando o projeto crítico de emancipação; de tal modo que, como afirma Hayden, os zapatistas eram simbólicos das novas forças revolucionárias, que desafiavam a modernidade, o monoculturalismo e a centralização do poder burocrático, sem procurar ser novos agressores. ${ }^{329}$ Nas palavras de Sebastião Vargas:

\begin{abstract}
A própria estrutura organizativa do EZLN, com os mandos militares subordinados às "autoridades civis" das comunidades e o esforço em consultá-las a cada impasse nas negociações entre o EZLN e o governo mexicano, demonstra como este "exército" singular tenta aplicar a si mesmo os princípios da uma democracia radical. Democracia, aliás, e não socialismo, que desde o princípio foi uma das demandas centrais dos insurgentes. Para se compreender o zapatismo há que se considerar três dimensões ou facetas que se interpenetram e se alimentam simultaneamente: a primeira é a dimensão local, com as demandas agrárias e étnicas tomando um lugar central nas reivindicações dos insurgentes; a segunda é a dimensão do zapatismo enquanto impulsionador de um movimento nacional que aspira inicialmente conquistar uma democracia de fato (contra a "ditadura perfeita" de mais de 80 anos do PRI) e construir um novo e alternativo projeto popular para o país, "a la isquierda y abajo"; a terceira dimensão da luta dos zapatistas aparece em âmbito latino-americano e global, com certo impacto sobre os movimentos indígenas da região e, principalmente, na considerável sedução e influência sobre a juventude do chamado movimento "antiglobalização" europeu e norteamericano. ${ }^{330}$
\end{abstract}

O Subcomandante Marcos criava nos discursos e comunicados um tipo de linguagem que se transforma em um novo modo de fazer política - que nada se parecia com a antiga linguagem burocrática ${ }^{331}$, a linguagem da "velha esquerda". Segundo Di Felice, “o sincretismo estilístico vira conteúdo, na medida em que nos comunicados juntam-se mundos simbólicos e códigos diferentes, realizando na forma literária uma utopia da nova sociedade de "um mundo onde caibam vários mundos"., 332

Esse lema utópico de "um mundo onde caibam vários mundos" configurava-se como um princípio universal baseado na ideia do diverso, o que, segundo Mignolo, não conferia uma contradição em termos, mas sim um deslocamento de estruturas conceituais. ${ }^{333}$ Tratava-se de direito à diferença na igualdade, possível de se construir

\footnotetext{
${ }^{328}$ In: MIGNOLO, p.37.

${ }^{329}$ HAYDEN, 2002, pp.5-6.

${ }^{330}$ VARGAS, 2006, p.101.

${ }^{331}$ MONSIVÁIS, 1995, pp.377-378.

332 DI FELICE, 1998, p.24.

${ }^{333}$ MIGNOLO, p.36.
} 
graças ao outro lema, qual seja, o de "mandar obedeciendo" (título de um comunicado de 26 de fevereiro de 1994, em que se repensa o conceito de poder ${ }^{334}$ ).

E era justamente Marcos a peça-chave para fazer possível essa proposição, seja na relação histórica que construía com os indigenas de Chiapas, em que se pese o fato de trazer consigo um outro substrato intelectual, étnico e de formação política; seja porque, após o $1^{\text {o }}$ de janeiro de 1994, sua figura conseguia, no plano simbólico, aglutinar (ou refletir, como defende Montalbán) a imagem dos diferentes tipos de oprimidos no mundo. Acompanhando o raciocínio de Mignolo, o Subcomandante Marcos era capaz de fazer a mediação entre esses dois mundos: colocando-se como "duplo tradutor", tem a tarefa de fazer a ponte de intercâmbio de referências que permite a efetividade da proposta zapatista.

não está falando sobre exportar conteúdos do levantamento zapatista (como se fossem projetos globais: cristandade, modernidade, missões civilizatórias ou desenvolvimento), mas, ao contrário, fala de conectar através da lógica da dupla tradução e a diferença colonial. A diversidade como projeto universal emerge, precisamente, como um projeto de interconexões a partir de uma perspectiva subalterna e mais além do poder de gestão e da inspiração monotópica de qualquer um dos universais abstratos - de esquerda a direita $^{335}$.

É evidente que o protagonismo de Marcos, por outro lado, gerava controvérsia: conforme lembra Conant (p.231), o fato do Subcomandante ter ganhado muito espaço trazia desilusão a alguns simpatizantes de um movimento que preza pela horizontalidade e transparência. ${ }^{336}$ De todo modo, no que se refere ao aspecto da utopia

\footnotetext{
${ }^{334}$ Cf. HOLLOWAY, 2003.

${ }^{335}$ MIGNOLO, p.37. No se está hablando de exporter contenidos del levantamiento zapatista (como si deseños globales se tratara: cristiandad, modernidad, misiones civilizatorias o desarollo), sino, en cambio, habla de conectar a través de la lógica de la doble traducción y la diferencia colonial. La diversalidad como proyecto universal emerge, precisamente, como un proyecto de interconexiones desde una perspectiva subalterna y más allá del poder de gestión y de la inspiración monotópica de cualquiera de los universales abstractos - de izquierda a derecha. MIGNOLO, p.37.

${ }^{336}$ Em suas próprias palavras em entrevista a Julio Scherer em 2001: "El error fundamental de Marcos es no haber cuidado - y yo lo perdono porque soy yo, y si no lo perdono yo, pues quién lo perdona, ¿no?-, no haber previsto esta personalización y protagonismo que muchas veces, si no es que la mayoría de ellas, impide ver qué es lo que está detrás. No nos angustia mucho como organización, porque nosotros sabemos lo que está detrás, y vemos una organización que puede sobrevivir incluso sin guerra... Esto no lo ha percibido mucha gente; tiene que ver mucho con que Marcos haya ofuscado, obstruido la vista hacia atrás. Que de una o otra forma, Marcos es responsable también en eso, sí, sí puede ser que su dosis de vanidad, de protagonismo o de payasez o como se llame eso, haya contribuido...”
} 
zapatista que se relaciona intimamente com o conteúdo que se permite manejar na figura do Subcomandante Marcos, ele próprio afirmou:

es decir, todos ven un pedazo del zapatismo que los refleja y los acerca. Pero ha de llegar un momento en que sí, abriendo este mundo plural, incluyente, tolerante, el EZLN tiene que adquirir rostro propio, eso és que lo decía. El pasamontañas va atener un limite. No me refiero al pasamontañas físico. Sino que este zapatismo naciente ha de concretarse de alguna forma. A mí me sorprendió el otro día que unos franceses dijeron: la indefinición es lo que les permite sobrevivir. ${ }^{337}$

El mérito del EZLN es el de haber encontrado la frecuencia de comunicación para que se produjera ese reflejo múltiple, que obtiene resultados en México urbano, en el México campesino y indígena. Pero también en otros países y en minorías excluidas de otros países. ${ }^{338}$

Portanto, o plano universal aglutinador da utopia zapatista repousava na ideia de dignidade, embasada no trinômio "democracia, liberdade ejustiça", bandeira do EZLN ainda que seja algo vagamente formulado, detinha o papel simbólico de denominador comum gerador de coesão para os diferentes sujeitos da transformação. ${ }^{339}$ E o EZLN enfatizava quem eram esses sujeitos, colocando-se "com os desorganizados sim, com os sem-rosto, como nós, com os sem nome, como nós, com os desprezados e marginalizados por não terem partido nem projeto político 'histórico', com eles sim. A partir de agora a história terá que tomá-los em conta, terá que nos tomar em conta". 340 Para José Rabasa, o Subcomandante Marcos é o conjunto de comunicados, entrevistas e discursos que emitiu. Marcos falava e escrevia em nome da coletividade, qual seja, os subalternos.

Em comunicado de 20 de janeiro de 1994, o Subcomandante Marcos falou sobre a relação com a sociedade civil, suas formas de luta e contradições inerentes ao movimento. A citação é longa, porém parece valer a menção, uma vez que revela muito de como a utopia zapatista começou a apontar para além da realidade dos indígenas de Chiapas (embora o comunicado afirmou exatamente o contrário nos primeiros parágrafos) e colocou a insurreição em outros termos:

\footnotetext{
${ }^{337}$ In: MONTALBÁN, p.71.

${ }^{338}$ In: MONTALBÁN, p.103.

${ }^{339}$ In: FIGUEIREDO, 2006, p.140.

${ }^{340}$ EZLN, 1994, p.302.
} 
Tenho a honra de ter como meus superiores os melhores homens e mulheres das etnias tzeltal, tzotzil, chol, tojolabal mam e zoque. Com eles vivi por mais de 10 anos e me orgulho de obedecê-los e servi-los com minhas armas e minha alma. Têm me ensinado mais do que agora ensinam ao país e ao mundo inteiro. Eles são meus comandantes e os seguirei pelas rotas que elejam. Eles são a direção coletiva e democrática do EZLN, sua aceitação do diálogo é verdadeira como verdadeiro seu coração de luta e verdadeira sua desconfiança de serem enganados de novo.

O EZLN não tem nem o desejo nem a capacidade de aglutinar em torno ao seu projeto e seu caminho os mexicanos todos. Mas têm a capacidade e o desejo de somar sua força à força nacional que anime o nosso país pelo caminho de justiça, democracia e liberdade que nós queremos.

Se tivermos que escolher entre caminhos, sempre escolheremos o da dignidade. Se encontramos uma paz digna, seguiremos o cainho da paz digna. Se encontramos a guerra digna, empunharemos nossas armas para encontrá-la. Se encontrarmos uma vida digna, seguiremos vivendo. Se, pelo contrário, a dignidade significa morte então iremos, sem duvidá-lo, a encontrá-la.

O que o EZLN busca para os indígenas de Chiapas deve ser buscado por toda organização honesta em todo o país para todos os mexicanos. O que o EZLN busca com as armas deve ser buscado por toda organização honesta com diferentes formas de luta.

Não tomaremos o país como refém. Não queremos e nem podemos impor à sociedade civil mexicana nossa ideia pela força de nossas armas, como faz o atual governo que impõe com a força das suas armas seu projeto de país. Não impediremos o processo eleitoral vindouro.

(...)

Nós pensamos que a mudança revolucionária no México não será produto da ação em um único sentido. Quer dizer, não será, em sentido estrito, uma revolução armada ou uma revolução pacífica. Será primordialmente uma revolução que resulte em várias formas de luta em várias frentes sociais, com muitos métodos, sob diferentes formas sociais, com graus diversos de compromisso e participação. E seu resultado será, não o de um partido, organização ou aliança de organizações triunfante com sua proposta social específica, senão uma sorte de espaço democrático de resolução de confrontação entre diversas formas políticas. Este espaço democrático de resolução terá três premissas fundamentais que são inseparáveis, já, historicamente: a democracia para decidir a proposta social dominante, a liberdade para subscrever uma ou outra proposta e a justiçaa que todas as propostas deverão cingir-se. A mudança revolucionária no México não seguirá um calendário estrito, poderá ser um furacão que estala depois de um tempo de acumulação, ou uma série de batalhas sociais que, paulatinamente, vão derrotando as forças contrárias. A mudança revolucionária no México não será sob uma direção única com uma única agrupação homogêna e um caudilho que a guie, mas uma pluralidade com dominantes que mudam mais giram sobre um ponto comum: o tríptico da democracia, liberdade e justiça sobre o que será o novo México ou não será.

A paz social só será se é justa e digna para todos.

O processo de diálogo para a paz vem de uma determinante fundamental, não da vontade política do governo federal, não de nossa suposta força político-militar (que para a maioria segue sendo um mistério), senão da ação firme do que chamam sociedade civil mexicana. Desta mesma ação da sociedade civil mexicana, e não da vontade do governo ou da força de nossos fuzis, sairá a possibilidade real de uma mudança democrática no México. (...) 
O Subcomandante Marcos, então, abriu o leque das possibilidades de emancipação a partir do zapatismo, ampliando o projeto crítico de transformação do qual era parte. Pode-se afirmar que o Marcos, sua máscara e sua performance delineiam junto com as forças do EZLN "o sentido global da proposta zapatista, uma certa travessia pelo espelho: é uma alternativa a revolução depois da revolução". 341 A ativista canadense Naomi Klein fornece um bom resumo sobre a novidade trazida pelo Subcomandante Marcos:

O mundo conta com um novo tipo de herói, aquele que ouve mais do que fala, aquele que prega na forma de enigmas e não de certezas, um líder que não mostra seu rosto, que afirma ser sua máscara na verdade um espelho. E nos zapatistas, não temos um sonho com a revolução, mas uma revolução sonhadora (tradução nossa). ${ }^{342}$

\footnotetext{
${ }^{341}$ MONTALBÁN, 1999, p.63.

${ }^{342}$ KLEIN, 2001, p.123. The world has a new kind of hero, one who listens more than speaks, who preaches in riddles not in certainties, a leader who doesn't show his face, who says his mask is really a mirror. And in the Zapatistas, we have not one dream of a revolution but a dreaming revolution.
} 


\section{Considerações Finais}

Neste trabalho, buscamos identificar os ponto cruciais para o entendimento do que a figura do Subcomandante Marcos representa historicamente. Pareceu-nos que sua figura, construída na esteira do processo de formação do movimento zapatista, adquire um caráter sui generis tal como as inovações trazidas pelo próprio movimento. Com efeito, nossa hipótese inicial era a de que o processo ocorria em uma via de mão dupla: além de sua importância pessoal (intelectual e política) como agente na formulação dos princípios zapatistas, Marcos dissolveu sua própria individualidade, representando a encarnação do ideário que propõe e congregando imageticamente em torno de si todos os novos sujeitos de sua revolução. De tal maneira que o Subcomandante, carismático e munido nas aparições públicas de seu aparato "icônico" - blusa militar, calça preta, coturno, cartucheiras no peito, boina, um fone de ouvido de comunicação de rádio, um relógio em cada pulso, balaclava e cachimbo - nutria-se dessa ambivalência entre os aspectos messiânicos que se coadunavam com o conteúdo de autonomia (enquanto exercício de livre determinação dos povos e organização horizontal) do próprio projeto utópico zapatista.

Buscamos enfatizar certos aspectos biográficos (antes e depois da ida a Chiapas; e após o levante do EZLN em 1994) que se relacionassem com a temática proposta neste trabalho, tentando identificar como se formou Rafael Guillén do ponto de vista político e intelectual, atentando para as transformações que o jovem urbano sofre no interior da Selva Lacandona até chegar a ser o Subcomandante Marcos, líder do movimento zapatista. Nos anos anteriores à sua ida a selva articulamos o contexto político e social em que Rafael estava inserido como forma de fornecer subsídios para o entendimento das razões pelas quais Guillén decide ir ao Estado, bem como para compreensão das referências da época que o informaram enquanto indivíduo. Nos anos em Chiapas, pudemos ver - considerando a perspectiva geral dos estudantes marxistas que formaram o EZLN - como se desempenhou o papel de Marcos no movimento, vinculando como suas convicções ideológicas (e mesmo o abandono delas) e sua personalidade influíram nos rumos, renovando sua formulação e práxis revolucionária. E após o levante, identificamos como o culto a Marcos - construído a partir de seu carisma - bem como o uso da máscara (e sua metáfora) fortaleceram sua imagem de anti-heroi contemporâneo. Como manifestou Carlos Fuentes, novelista e diplomata 
mexicano, o Subcomandante Marcos foi "um dos primeiros atores pós-comunistas no palco do Terceiro Mundo".

Evidentemente que o desmascaramento do Subcomandante Marcos pelo presidente Zedillo tirou toda a aura de encantamento que o zapatista provocava. Ao revelar a face de Rafael Sebastián Guillén Vicente - professor universitário sem o mesmo charme do guerrilheiro revolucionário - complexificou sua figura; como ele próprio disse, o governo mexicano descobriu que o "fora-da-lei" não tinha sequer multas de trânsito. ${ }^{343} \mathrm{Se}$, como dissemos na introdução deste trabalho, o Subcomandante defendia que há três Marcos diferentes (antes da ida a Chiapas, em Chiapas em atividades clandestinas e após o levante de 1994), nos parece que, mesmo com toda a mudança que a vida na selva lhe proporcionou, há muito de Guillén no Subcomandante Marcos, como era de se esperar - em mais uma das tensões que animam sua figura. Já em 23 de fevereiro de 1994, ele afirmou com clareza da natureza contraditória do movimento a que faz parte que "escolhemos esse caminho suicida de uma profissão cujo objetivo é desaparecer: soldados que são soldados para que um dia ninguém tenha que ser soldado" (EZLN, 1994, 166). Se o EZLN nasceu para o mundo no dia $1^{\circ}$ de janeiro, o significado da figura do Subcomandante Marcos nos parece, em boa medida, residir na metáfora que se pode extrair do deus romano Jano - que dá origem à palavra janeiro: Jano é representado com duas faces, uma olhando para frente e outra para trás. No paralelo traçado, o Subcomandante Marcos anuncia um futuro radicalmente diferente, mas, ao mesmo tempo, que reproduzia as contradições do passado ao qual está ligado. Nas palavras de Jeff Conant:

O caráter ou personalidade de Marcos é, de fato, profundamente paradoxal: poeta e comandante militar, mestiço urbano e voz dos camponeses indígenas, feminista confesso e machista prepotente, líder e subordinado, sabedoria pública e clandestino, revolucionário armado. Como observa a teórica literária Kristine Berghe: 'o auto-retrato de Marcos tem muito de anti-herói; ele é fragmentado e construído por contradições. Marcos é indígena e ao mesmo tempo não é, desempenha papel de subordinado, mas ao mesmo tempo exerce enorme influência; ele é Sancho Panzo, mas ao mesmo tempo é Don Quixote; é uma figura inútil na floresta e líder militar do EZLN. Em outras palavras, é uma figura cujas características mudam de acordo com o momento político e as exigências da guerra. 344

\footnotetext{
${ }^{343}$ FUSER, 1995, p. 188.

${ }^{344}$ CONANT, 2010, p.241.
} 
E a literatura muito discutiu em que medida a visibilidade de Marcos ofuscou a causa zapatista; ou, ao contrário, em que medida a "Marcosmania" e seus efeitos ajudaram a alçar o EZLN e os indígenas de Chiapas a patamares inesperados. Se de início a expectativa de Marcos era de que se construísse uma sublevação popular localizada, podemos afirmar que, em balanço dos anos da aparição pública de Marcos em que observamos, se transformou em símbolo da luta contra o neoliberalismo. Na opinião de Nick Henck, seu carisma elevou a luta zapatista: colocou-a nos holofotes, mais do que alimentou o ego de seu líder. ${ }^{345}$ Já Grange e Rico acreditam no oposto: a Marcos pode-se atribuir um único êxito, qual seja, "ter aberto a caixa de Pandora ao desmascarar o discurso oficial do PRI"; ${ }^{346}$ de resto, para eles, Marcos pode ser desqualificado como um "impostor genial".

Embora, como mencionamos, a posteriori Marcos tenha revisto criticamente seu papel protagonista na mídia, por várias vezes ele afirmou que sua fama e causa zapatista estavam intrinsecamente entrelaçadas; de tal modo que não se pudesse contestar seu comprometimento com os indígenas de Chiapas pelo fato de sua figura ter ficado sob os holofotes. Em declaração no mês de maio de 1995, Régis Debray deu sua contribuição acerca do significado de Marcos, com a qual nos alinhamos:

Zapata revisado por Brecht. Se existe narcisismo é às avessas, para sacudir nossa passividade. Talvez Marcos tenha compreendido que na atualidade o virtual sempre vence o real, a oposição ao Governo e o personagem ao indivíduo. Assim, transforma sua máscara em um espelho com facetas nas quais todo o mundo pode refletir-se à vontade.

Os banqueiros ideólogos haviam repelido o camponês e o verbo, que um belo dia explodiu em sua frente através de uma figura improvável e cada vez mais necessária: o patriota multilíngue, o universalista com raízes. Marcos é um ultramexicano, habitado pelos fantasmas de sua nação, por suas canções infantis e lendas, mas ao mesmo tempo está conectado com San Diego, Berkeley e Paris e com todas as novas formas da cultura mundial. Despertando mitos enterrados, essa prosa modesta traçaria um novo futuro do meio continente, pelo mero fato de retomar os fios de uma história esquecida. Os zapatistas não respondem à imagem com a imagem, ao tópico com o tópico. Frente às pesquisas e à televisão, utilizam a memória e a palavra impressa. Sem grandiloquência. Um passo ao lado, e o gesso vem abaixo (tradução nossa). ${ }^{347}$

\footnotetext{
${ }^{345}$ HENCK, 2007, p.239.

${ }^{346}$ GRANGE e RICO, 1998, p.429.

${ }^{347}$ http://elpais.com/diario/1995/03/22/opinion/795826807 850215.html
} 
O Subcomandante Marcos não nos pareceu ser o "homem novo", mas - tal qual ele mesmo acreditava - ser a ponte para que se pudesse construir um mundo novo, fundamentado na democracia, justiça e liberdade - um "mundo onde caibam vários mundos". Por enquanto, Marcos e sua máscara permitiam representar essa igualdade na diferença, ao mesmo tempo em que exercia sua liderança de modo proeminente em um cenário marcado pela ideia de "fim das utopias". Se por um lado, o Subcomandante Marcos agarrava o espaço que lhe era dado, por outro lado, afinal, se fazia mandar obedecendo. E tudo isso em um manifesto algo messiânico em que se colocava integralmente a serviço de sua revolução (para que seja possível fazer acontecer a revolução), de tal maneira que reconhecia que ele e os zapatistas "nasceram da noite, vivemos e morreremos nela" e assim desejava "para nós nada; para todos, tudo". ${ }^{448}$ As palavras de Jeff Conant vão ao encontro de nossa visão "a figura de Marcos é muito mais do que um ícone individual e de fato encarna, talvez mais do que qualquer indivíduo consiga, a agência coletiva que é o núcleo da ética zapatista e dos projetos zapatistas de transformação do mundo, do estado nação, ou ao menos do sudeste mexicano. $^{349}$

Demos o título desta pesquisa de "Para Além do Cachimbo de Magritte: Messianismo e Utopia na Construção da Figura do Subcomandante Marcos”. O uso frequente do cachimbo era parte constituinte da construção de Marcos como figurasímbolo, a tal ponto de um artigo sobre ele do jornal La Jornada ter sido intitulado de "O Cachimbo Parlante". Ao lado de pessoas como Sigmund Freud, Jean-Paul Sartre e Joseph Stalin - apenas para citar alguns -, o Subcomandante Marcos torna o cachimbo uma marca registrada em fotografias e vídeos, fazendo uso do instrumento em diversas entrevistas - considerando-se, ainda, o uso tabaco enquanto tradicional e notório agente de êxtase ritual. O título de nossa pesquisa, além da referida alusão, dialoga com a obra do pintor surrealista belga René Magritte (1898-1967) “A Traição das Imagens”, de

\footnotetext{
348 Trecho do Manifesto Zapatista em Nahuatl: "no morirá la flor de la palabra, podrá morir el rostro oculto de quien la nombra hoy, pero la palabra que vino desde fondo de la historia y de la tierra ya no podrá ser arrancada por la soberbia del poder. Nosotros nacimos de la noche. En ella vivimos, moriremos en ella. Pero la luz será mañana para los más, para todos aquellos que hoy lloran la noche, para quienes se niega el día, para quienes es regalo la muerte, para quienes está prohibida la vida. Para todos la luz. Para todos todo. Para nosotros la alegre rebeldía, para nosotros nada. Aquí estamos! Somos la dignidad rebelde, el corazón olvidado de la patria!”
}

${ }^{349}$ CONANT, 2010, pp.241-242. 
1928, que contém a famosa inscrição “Ceci n'est pas une pipe” (“Isto não é um cachimbo"), cuja interpretação imediata é de que aquilo de fato não seria um cachimbo, mas sim a representação de um cachimbo. ${ }^{350} \mathrm{Na}$ alegoria aqui travada, o Subcomandante Marcos, enquanto ícone, pareceu ser o sujeito revolucionário, a representação de todos os sujeitos revolucionários e a encarnação do próprio ideário revolucionário.

Em resumo, a figura do Subcomandante Insurgente Marcos apontava para a perspectiva de uma humanidade verdadeiramente livre, ao mesmo tempo em que resgatava as heranças da história mexicana; ela repousava em suas próprias contradições; carregava símbolos tipicamente chiapanecos, bem como outros modernos; trazia referências universais e outras tão próprias a seu tempo; e se refazia constantemente enquanto representava a miríade dos excluídos de todo mundo. Seguimos, assim, a linha que defendeu Alain Touraine à época do levante zapatista:

A história vai se lembrar da coragem física, política e intelectual do Subcomandante Marcos, um sociólogo a cavalo, um mestiço entre indígenas, um patriota mexicano e revolucionário global militante, que arrisca sua vida para uma vez mais unir, na América Latina e em outros lugares, a luta revolucionária e a liberdade política. ${ }^{351}$

\footnotetext{
${ }^{350} \mathrm{Na}$ década de 60, o filósofo francês Michael Foucault complexificou a questão, debatendo com Magritte a questão da representação pictórica e da semiótica.

${ }^{351}$ In: MEYER, 2002, p.368.
} 


\section{Referências Bibliográficas}

ARELLANO, A. B.; OLIVEIRA, A. U. (Org.). Chiapas: construindo a esperança. São Paulo: Paz e Terra, 2002.

AVILÉS, J.; MINÀ, G. Marcos y la Insurreción Zapatista. Cid. Mexico: Ed. Grijalbo, 1998.

BARKIN, David. "Globalization and Resistance: the remaking of Mexico". NACLA Report on the Americas, 30, n.4, 1997.

BASCHET, Jérôme. L'étincelle Zapatiste: Insurrection Indienne et Résistance Planétaire. Paris: Denoël, 2004.

BENJAMIN, Medea. "First World, Ha! Ha! Ha! The Zapatista Challenge" Interview: Subcomandante Marcos”. City Lights Books, San Francisco 1994. pg.70.

BENJAMIN, Thomas. "A Time to Reconquest: History, the Maya Revival, and the Zapatista Rebellion in Chiapas". The American Historical Review. 105(2): 417440, 2000.

BENJAMIN, Thomas. A Rich Land, a Poor People: Politics and Society in Modern Chiapas. Albuquerque: University of New Mexico Press. 1996.

BELAUTESGUIGOITIA, R. "Mascaras y Posdatas: estrategias femeninas en la rebellion indigena de Chiapas". Estudos Feministas, UFRJ, 1996.

BENSAÏD, Daniel. "Marcos e o Espelho Partido da Mundialização". Em Tempo, no mar/abr, 1998.

BERGER, Mark T. "Romancing the Zapatistas: International Intellectuals and the Chiapas Rebellion”. Latin American Perspectives 28(2): 149-170, 2001.

BUENROSTRO y ARELLANO, Alejandro. As Raízes do Fenômeno Chiapas: o Já Basta da Resistência Zapatista. São Paulo: Alfarrábio, 2002.

BURBACH, Roger. Globalization and Postmodern Politics. London: Pluto Press, 2001.

CASTAÑEDA, J.G. Utopia Desarmada. São Paulo: Companhia das Letras, 1994.

CASTAÑEDA, J.G.The Mexican Shock: its meaning for the United States. NY: NY Press, 1995.

CASTAÑEDA, J.G. Compañero: the life and death of Che Guevara. NY: Knopf, 1997.

CASTELLANOS, Laura. Corte de Caja: entrevista al Subcomandante Marcos. Mexico: Grupo Ed. Endira Mexico, 2008.

CASTELLS, Manuel. O Poder da Identidade. São Paulo: Paz e Terra, 1999. 
CASTILlO, Rosalva Aída Hernández. Histories and Stories from Chiapas: Border Identities in Southern Mexico.Texas: University of Texas Press, 2001.

CECEÑA, Ana E.. "Pela humanidade e contra o neoliberalismo - linhas centrais do discurso zapatista". In.: SEONE, J. \& TADDEI, E. Resistências mundiais - de Seattle a Porto Alegre. Rio de Janeiro: Vozes, 2001.

CETENO, Miguél Angél. Democracy with Reason: Technocratic Revolution in Mexico. Pennsylvania University Press, 1994.

CHOMSKI, Noam Chomsky; KLEIN, Naomi Klein; MARCOS, Subcomandante Insurgente; VODOVNIK, Ziga. Ya Basta! Ten Years of the Zapatista Uprising. Oakland: AK Press, 2004.

COLINA, José de La. “As Time Goes By: 'Marcos', or The Mask is the Message". Letras Libras, 1999, In: HAYDEN, 2002.

COLLIER, George A; QUARATIELLO, Elizabeth Lowery. Basta! Land and the Zapatista Rebellion in Chiapas. Oakland: The Institute for Food and Development Policy, 1999.

CONANT, Jeff. A Poetics of Resistance: the Revolutionary Public Relations of the Zapatista Insurgency. Oakland, CA: AK Press, 2010.

CONDEARENA, L. Chiapas: el despertar de la esperanza. Espanha: Tercera Prensa, 1997.

CORRO, Salvador. "Ces; areo Morales y Alberto Híjar evocan los años setenta, cuando se gustaba la insurreción”, Proceso, n.979, Agosto, 1995.

CRESPO, Regina Aída. "Chiapas: O movimento indígena armado no panorama político e econômico do México". Terra Indígena, ano 13, n. 80, p. 31-45, 1996.

DI FELICE, M.; BRIGE, M. F. (Org.). Votán-Zapata: A marcha indígena e a sublevação temporária. São Paulo: Xamã, 2002.

DI FELICE, M.; BRIGE, M. F.; MUÑOZ, C. (Org.). A revolução invencível: Subcomandante Marcos e Exército Zapatista de Libertação Nacional - Cartas e Comunicados. São Paulo: Boitempo, 1998.

DURÁN DE HUERTA, Marta. Yo, Marcos. Ciudad de Mexico: Milenio, 1994.

DUTERME, Bernard. "Os Dez Anos da Revolução Zapatista em Chiapas”. Le Monde Diplomatique, 2004.

ESPINOSA, Javier. "La verdadera historia del subcomandante Marcos”, El Mundo, 26 de fevereiro de 1995 
FIGUEIREDO, Guilherme Gitahy de. A Guerra é o Espetáculo: Origens $e$ Transformações do Exército Zapatista de Libertação Nacional. São Carlos: RiMa, FAPESP, 2006.

FLORESCANO, Enrique. Memoria Mexicana. Mexico: FCE, 2002.

FUSER, Igor. México em Transe. São Paulo: Scritta, 1995

FUKUYAMA, F. O Fim da História e o Último Homem, Rio de Janeiro: Rocco, 1992.

GABRIEL, Leo; LÓPEZ y RIVAS, Gilberto (coord.) (2005). Autonomías indígenas en América Latina: Nuevas formas de convivencia política. México, DF: Plaza y Valdes editores, 2005.

GARCÍA DE LEÓN, Antonio. Prólogo: "El Jaguar de la Noche". In: EZLN, Documentos y Comunicados, 1 de enero / 8 de agosto de 1994 (vol.1). Mexico: Ed. Era, 2003.

GENNARI, Emilio. Chiapas: as comunidades zapatistas reescrevem a história. Rio de Janeiro: Achiamé, 2002.

GILBRETH, Chris; OTERO, Gerardo. "Democratization in Mexico: The Zapatista Uprising and Civil Society”. Latin American Perspectives 28(4): 7-29, 2001.

GILLY, Adolfo. "Chiapas and the Rebellion of the Enchanted World". In: NUGENT, Daniel. Rural Revolt in Mexico. Durham: Duke University Press, 1998.

GIRARDET, Raoul. Mitos e Mitologias Politicas. SP: Cia das Letras, 1987.

GOLLNICK, Brian: Reinventing the Lacandon: Subaltern Representations in the Rain Forest of Chiapas, University of Arizona Press, 2008

GONZÁLEZ, Mike. "The Zapatistas: the challenges of revolution in the new millennium". In: HAYDEN, Tom. The Zapatista Reader. New York: Nation Books, 2002.

GOSSEN, Gary. "Comments on the Zapatista Movement". Cultural Survival Quarterly 18(20), 1994.

GOSSEN, Gary. "Maya Zapatista Move into the Ancient Future". American Anthropologist: New Series 98(3): 528-538, 1996.

GRANGE, Bertrand de la; RICO, Maité. Marcos: La Genial Impostura. Madrid: Alfaguara, Santillana Ediciones Generales, 1997.

GUILLERMOPRIETO, Alma. “The Unmasking”. The New Yorker, March 13, 1995. In: HAYDEN, 2002.

GURZA, L. A. “A Longa Transição: eleições e regime político no México". Novos Estudos. n.58, pp.5-28, 2000. 
HAMNETT, Brian R. A Concise History of Mexico. Cambridge: Cambridge University Press, 2006.

HARVEY, Neil. "Rebellion in Chiapas: Rural Reforms and Popular Struggle". Third World Quarterly, Vol. 16, No. 1 (Mar., 1995), pp. 39-73, 1998.

HASS, Antonio. "Marcos: Maestro de la Teatralidad”. Siempre! 47, n.2491, fev., 2001.

HAYDEN, Tom. The Zapatista Reader. New York: Nation Books, 2002.

HENCK, Nick. Subcommander Marcos: The Man and the Mask. London: Duke University Press, 2007.

HERNÁNDEZ NAVARRO, Luis. Chiapas, la nueva lucha india. Madrid: Talasa, 1998.

HIGGINS, Nicholas P. Understanding the Chiapas Rebellion: Modernist Visions and the Invisible Indian. Texas: University of Texas Press, 2004.

HOLLOWAY, J. "O Zapatismo e as Ciências Sociais na América Latina". Revista Novos Rumos 36(17), 2002.

HOLLOWAY, John. Mudar o Mundo Sem Tomar o Poder. São Paulo: Boitempo, 2003.

HUERTA, Marta Duran de; HIGGINS, Nicholas. "An Interview With Subcomandante Marcos: Spokesperson and Military Comander of Zapatista National Liberation Army (EZLN)". International Affairs, Vol. 75, No 2, Abril 1999, pp. 169-179.

JACOBY, Russel. O Fim da Utopia: política e cultura na era da apatia. Rio de Janeiro: Record, 2001.

KELLY, Thomas J. "Neoliberal Reforms and Rural Poverty". Latin American Perspectives 28(3): 84-103, 2001.

KLEIN, Naomi. "Farewell to the End of History: Organization and Vision in AntiCorporate Movements". The Socialist Register, 2002.

KLEIN, Naomi. "The Unknown Icon”. The Guardian, March 3, 2001. In: HAYDEN, 2002.

KLEIN, Naomi. Cercas e Janelas: Na linha de frente do debate sobre Globalização. Rio de Janeiro: Editora Record, 2003.

KLESNER, Joseph L. “The End of Mexico's One Party Regime”. PS: Political Science and Politics, Vol. 34, No 1, Mar. 2001, pp. 107-114.

KRAUZE, Enrique. Mexico: Biography of Power. NY: Harper Collins, 1997.

LANDAU, Saul. "In the Jungle with Marcos: an Interview". Progressive, pp.25-30, 1996. 
LAWRENCE, Carl. The Cross and the Sword: the rebellion and revolution in Chiapas, Mexico. California: Shannon Publ., 1999.

LE BOT, Yvon. O sonho zapatista. Lisboa: Asa, 1997.

LÖWY, Michael e BENSAÏD, Daniel. Marxismo, modernidade e utopia. São Paulo, Xamã, 2000.

LÖWY, Michael. "Eric Hobsbawm: Sociólogo do Milenarismo Campesino". Estudos Avançados, vol.24, n.69, 2010.

LÖWY, Michael. "Fontes e Recursos do Zapatismo". Em Tempo, n 296/297, outubro de 1997.

LÖWY, Michael. Romantismo e Messianismo: ensaios sobre Lukács e Benjamin. São Paulo: Perspectiva/Edusp, 1990.

LÖWY, Michael; SAYRE, Robert. Revolta e Melancolia: o Romantismo na contramão da modernidade. Petrópolis: Vozes, 1995.

LYND, Staughton, GRUBACIC, Andrej. Wobblies and Zapatistas: Conversations on Anarchism, Marxism and Radical History. PM Press, 2008.

MACHÍN, Juan. "Hoy, ¿Generación se escreve com Z?”. Revista Generación Z. Cultura Jovem, A.C., 1998.

MARCOS, Subcomandante. Detrás de Nosotros Estamos Ustedes. Barcelona: Plaza y Janés Editores, 2000.

MARCOS, Subcomandante. EZLN Communiques: Memory from Below. Oakland, CA: Regent Press, 1999.

MARCOS, Subcomandante. Mexico: A Storm and a Prophecy. Westfield, NJ, 1994a.

MARCOS, Subcomandante. Speed of Dreams: Selected Writings 2001-2006. San Francisco: City Lights Books, 2007.

MARCOS, Subcomandante. Voice of Fire. Berkeley, CA, New Earth Press, 1994b.

MARKMAN, Roberta; MARKMAN, Peter. The Flayed God: the mythology of Mesoamerica, sacred texts and images from pre-Columbian Mexico and CentralAmerica. San Francisco: Harper S. Francisco, 1992.

MARQUEZ, G; POMBO, R. "The Punch Card and the Hourglass: Interview with Marcos”. New Left Review, May - June 2001.

McCAUGHAN, Michael. "King of the Jungle". Irish Times, August 5, 1999. In: HAYDEN, 2002. 
MENESES, Juan Anzaldo. "Mascaras y Sombras: del conceptco ritual a la pratica cuotidiana del anonimato". Ce-Acteal, n.81, Junho de 1996.

MENTINIS, Mihalis. Zapatistas: The Chiapas Revolt and What It Means for Radical Politics. London: Pluto Press, 2006.

MERGIER, Anne Marie. "Los inicios de la UAM-Xochimilco, una experiencia inedita en la historia de la Universidad Mexicana: Raul Velasco Ugalde”. Proceso, n.981, Agosto de 1995.

MEYER, Jean. "Once Again, The Noble Savage". Letras Libras, 1999. In: HAYDEN, 2002.

MEYER, Michael C. The Oxford History of Mexico. Oxford: Oxford University Press, 2000.

MIGNOLO, Walter. "La revolución teórica del Zapatismo: sus consecuencias históricas, éticas y políticas”, 2010.

MONSIVAÍS, Carlos. "From the Subsoil that the Mask Reveals: The Visible Indian". Proceso, Mar, 1995. In: HAYDEN, 2002.

MONTALBÁN, Manuel Vázquez. Marcos: el Señor de los Espejos. Madrid: Aguilar, 1999.

MONTEMAYOR, Carlos. Chiapas, La Rebélion Indígena de México. Madrid: Espasa, 1998.

NASH, June. "The Zapatista Uprising and Radical Democracy in Mexico". American Anthropologist: New Series 99(2): 261-274, 1997.

NUGENT, Daniel. Rural Revolt in Mexico. Durham: Duke University Press, 1998.

OPPENHEIMER, Andres. Bordering in Chaos. Boston: Little Brown, 1996.

ORTIZ, Pedro H. F. “Ya Basta!”. Atenção, 2(8), 1996.

ORTIZ, Pedro; BRIDGE, Marco; FERRARI, Rogério. Zapatistas: a Velocidade do Sonho. Brasília: Entrelivros, Thessaurus, 2007.

PEREYRA, Daniel. Del Moncada a Chiapas: Historia de la lucha armada en America Latina. Madrid: Los Libros de Catarata, 1994.

PETRAS, J. \& VIEUX, S. "Mitos e realidades da sublevação de Chiapas". Lutas sociais n. 05, São Paulo, 1998.

POITRAS, Guy, ROBINSON, Raymond. "The Politics of NAFTA in Mexico". Journal of Interamerican Studies and World Affairs. Vol. 36, N 1, 1994. 
PONIATOWSKA, Elena. La noche de Tlatelolco. Testimonios de historia oral. Ed. Era, 1971.

PONIATOWSKA, Elena. "Voices from the Jungle". Distant Relations, 1995. In: HAYDEN, 2002.

PONCE DE LEÓN, Juana; MARCOS, Subcomandante; Our Word is Our Weapon. Toronto: Seven Stories Press, 2001.

PORRO, Antonio. Messianismo Maya no Periodo Colonial. SP: FFLCH-USP, 1991.

QUEIROZ, Maria Isaura Pereira. O Messianismo no Brasil e no Mundo. SP: AlfaOmega, 2003.

RABASA, José. Without History: sulbaltern studies, the zapatista uprising and the specter of history. Pittsburgh: Univ. of Pittsburgh Press, 2010.

RAMÍREZ, Gloria M. The Fire and the Word: A History of the Zapatista Movement. California: City Lights Publishers, 2003.

RAMONET, Ignacio. Marcos. La dignité rebelle. Paris: Galilée, 2001.

REYES, F. A.; ZEBADUA, C. M. Samuel Ruiz: su lucha por la paz en Chiapas. Mexico DF: Milenio, 1995.

ROSS, John. The War Against Oblivion: the Zapatista Chronicle in Chiapas, 19942000. Maine: Commom Courage Press, 2000.

RUIZ, Ramon Eduardo. Triumphs and Tragedy: A History of the Mexican People. New York: W.W. Norton \& Co., 1993.

SALIBA, Elias Thomé. As Utopias Românticas. São Paulo: Estação Liberdade, 2003.

SHEAHAN, John. "Effects of Liberalization Programs on Poverty and Inequality: Chile, Mexico and Peru". Latin American Research Review, Vol. 32, No 3, 1997, pp. 7-37.

SIMON, Joel. "The Marcos Mystery: A Chat with the Subcommander of Spin". Columbia Journalism Review, Sept, 1994. In: HAYDEN, 2002.

SOLARIS, Martín. “Cuando Marcos era Rafael”. La Jornada, 25 de fevereiro de 1996.

STAVANS, Ilan. “Unmasking Marcos”. Transition, 1996.In: HAYDEN, 2002.

STAVENHAGEN, Rodolfo. Tres perspectivas sobre el conflicto en Chiapas. Mimeo. Conferência. 1999.

STEPHEN, Lynn. Zapata Lives! Histories and Cultural Politics in Southern Mexico. Berkeley: University of California Press, 2002.' 
TELLO DÍAZ, Carlos. La Rebelión de las Cañadas. Cid. Méx: Ed. Cal y Arena, 1995.

VARGAS, Sebastião. Mística de Resistência: culturas, histórias e imaginários rebeldes nos movimentos sociais latino-americanos. Tese (Doutorado em História Social) Faculdade de Filosofia, Letras e Ciências Humanas, Universidade de São Paulo, São Paulo, 2007.

VASQUEZ, Adolfo Sanchez. Entre a Realidade e a Utopia: ensaios sobre politica, moral e socialismo. RJ: Civilização Brasileira, 2001.

VELTMEYER, Henry. "The Dynamics of Social Change and Mexico's EZLN". Latin American Perspectives 27(5): 88-110, 2000.

WALLERSTEIN, Immanuel. "Turbulência no México: Sublevação ou guerra civil?”. Fernand Braudel Center, Binghamton University, 199, 2006.

WEINBERG, Bill. Homage to Chiapas: The New Indigenous Struggles in Mexico. London: Verso, 2002.

WILLES, D. Greek Theatre in Performance: an introduction. Cambridge: Cambridge Univ. Press, 2000

WOMACK Jr., John. Rebellion in Chiapas: An Historical Reader. New York: The New Press, 1999.

ZEBADUA, Emilio.Breve Historia De Chiapas. Fondo de Cultura Economica USA, 1999. 